UNIVERSIDADE DE SÃO PAULO

FACULDADE DE ADMINISTRAÇÃO, ECONOMIA E CONTABILIDADE

DEPARTAMENTO DE ADMINISTRAÇÃO

PROGRAMA DE PÓS-GRADUAÇÃO EM ADMINISTRAÇÃO

Importação de tecnologia gerencial para gestão do fornecimento de serviços de TI: um estudo sobre a aplicabilidade do modelo eSourcing Capability Model ao contexto institucional brasileiro

Hebbertt de Farias Soares

Orientador: Prof. Dr. Nicolau Reinhard 
Profa. Dra. Suely Vilela

Reitora da Universidade de São Paulo

Prof. Dr. Carlos Roberto Azzoni

Diretor da Faculdade de Economia, Administração e Contabilidade

Prof. Dr. Isak Kruglianskas

Chefe do Departamento de Administração

Prof. Dr. Martinho Isnard Ribeiro de Almeida

Coordenador do Programa de Pós-Graduação em Administração 
HEBBERTT DE FARIAS SOARES

\section{IMPORTAÇÃO DE TECNOLOGIA GERENCIAL PARA GESTÃO DO FORNECIMENTO DE SERVIÇOS DE TI: UM ESTUDO SOBRE A APLICABILIDADE DO MODELO eSOURCING CAPABILITY MODEL AO CONTEXTO INSTITUCIONAL BRASILEIRO}

Dissertação apresentada ao Departamento de Administração da Faculdade de Economia, Administração e Contabilidade da Universidade de São Paulo como requisito parcial para obtenção do título de Mestre em Administração.

Orientador: Prof. Dr. Nicolau Reinhard 


\section{FICHA CATALOGRÁFICA}

Elaborada pela Seção de Processamento Técnico do SBD/FEA/USP

Soares, Hebbertt de Farias, 1985 -

Importação de tecnologia gerencial para gestão do fornecimento de serviços de TI : um estudo sobre a aplicabilidade do modelo eSourcing Capability Model ao contexto institucional brasileiro / Hebbertt de Farias Soares

-- São Paulo, 2008

$143 \mathrm{p}$.

Dissertação (Mestrado) - Universidade de São Paulo, 2008

Bibliografia.

1. Terceirização 2. Tecnologia da informação - Tecnologia 3. Análise de conteúdo I. Universidade de São Paulo. Faculdade de Economia, Administração e Contabilidade II. Título.

CDD -658.4058 


\section{AGRADECIMENTOS}

A todos os professores que me conduziram pelo caminho do conhecimento. As vezes em forma de aulas expositivas, em outras através de conversas, leituras e exemplos de vida. Indepedentemente do modo, todos, sempre, agregando valores, reflexões, conhecimentos e ética para uma vida mais digna.

Em especial ao Prof. Nicolau por investir o seu escasso tempo e dedicada atenção na condução da orientação. Mais do que um orientador acadêmico, antes um exemplo de vida. Obrigado pelo investimento de risco!

À Raquel, pelo seu amor, atenção, companheirismo, bondade, paciência... muita paciência, que, como um anjo, me suportou mesmo com toda minha grosseria e estresse, me guiou pela trevas dos pesadelos de achar que o sonho estava longe de ser alcançado e fez mais que qualquer pessoa até este momento de minha vida, ao me amar tão ardentemente que, às vezes, me questiono se sou merecedor de tanto.

À toda minha família que com toda sua idiossincrasia me fizeram ser o que sou.

À Lícia e Edson pela companhia, apoio, sugestões, almoços e cafés.

Aos prof. Edmir e profa. Leila pelos comentários da banca de qualificação.

Aos meus companheiros de mestrado Ane, Fábio e Roberto, sempre presentes nos seminários e nos bares da vida.

À Ricardo pelos ensinamento de microeconomia, econometria e cálculo.

Ao PROINFO/FIA pelo apoio logístico.

Ao CNPq pela bolsa de estudos. 


\section{RESUMO}

A governança do fornecimento (sourcing) de serviços de tecnologia da informação (TI) é uma questão que abrange aspectos gerenciais, econômicos e sociais. Atualmente parte significativas das recomendações de mercado orientam para a adoção de modelos padronizados cujas recomendações são consideradas "melhores práticas". Dentre as existentes, o modelo eSourcing Capability Model (eSCM), desenvolvido pelo Information Technology Services Qualification Center da Universidade Carnegie Mellon, destina-se exclusivamente à padronização das práticas de sourcing. A pesquisa empreendida questiona quais as implicações das premissas do modelo eSCM para sua adequabilidade ao contexto institucional brasileiro. Foram realizadas análises de conteúdo para identificação das premissas explícitas e implícitas. Ao final dessa etapa identificou-se doze premissas, as quais foram comparadas com uma caracterização das especificidades do ambiente institucional brasileiro. Por sua vez, essa caracterização foi validada com especialistas. Conclui-se que o modelo eSCM traz uma grande contribuição para a prática da gestão do sourcing que é a preocupação com a gestão por processos e um gerenciamento profissional. Outra contribuição significativa do modelo é o foco no alinhamento dos estratégias e operações. Contudo, o modelo está fundamentado em uma lógica que presume uma racionalidade e formalismo que não são compatíveis com a cultura brasileira. São elementos que, historicamente, quando importados para o nosso contexto degeneraram-se e criaram arranjos ambigüos.

Palavras-chave: Fornecimento de serviços de tecnologia da informação, governança de sourcing, eSourcing Capability Model, análise de conteúdo, análise comparativa. 


\begin{abstract}
Information technology services sourcing governance is an issue with economic, managerial and social dimensions. To approach it many frameworks have been develloped. This research addresses the adequacy of eSourcing Capability Model (eSC) to the Brazilian institutional context. The research design was based on content analysis and comparative analysis. It was found 12 premisses that underlie the eSCM. They were validated with experts. The conclusion points that eSCM brings professionalism to sourcing management. However, the model is based on rationality and formalism not compatible with Brazilian culture. Those elements was previously imported and degenerated to alternative institutional arrangements,

Key-words: IT service sourcing, sourcing governance, eSourcing Capability Model, content analysis, comparative analysis.
\end{abstract}




\section{SUMÁRIO}

1 Introdução 13

1.1 Exposição do assunto . . . . . . . . . . . . . . . . . 13

1.2 Estrutura do trabalho . . . . . . . . . . . . . 17

1.3 Contribuições . . . . . . . . . . . . . . . . . . 18

2 Governança do fornecimento de serviços $\quad 19$

2.1 Definindo a governança . . . . . . . . . . . . . . 21

2.2 Questões associadas com a governança de sourcing . . . . . . . . . . . . . 22

2.2.1 Arranjos contratuais ...................... 22

2.2.2 Precificação e desempenho dos contratos . . . . . . . . . . . 22

2.2 .3 Riscos no sourcing ....................... 23

2.2.4 Compartilhamento de conhecimento . . . . . . . . . . . . . 24

2.3 Modelos para governança . . . . . . . . . . . . . . . 28

3 Mecanismos de governança $\quad 31$

3.1 Introdução ao capítulo . . . . . . . . . . . . . . . 31

3.2 Governança por meio dos mecanismos de mercado $\ldots \ldots . \ldots . \ldots$

3.2.1 As preferências do consumidor e a racionalidade . . . . . . . . . 39

3.2 .2 A firma na teoria clássica . . . . . . . . . . . . 41

3.2.3 Equilíbrio geral competitivo ................. 43

3.3 Governança por meio dos mecanismos contratuais . . . . . . . . . . . . 44

3.3.1 Da firma ideal às formas híbridas . . . . . . . . . . . . 46

3.3.2 Escolha da estrutura de governança . . . . . . . . . . . . . 49 
3.3.3 Riscos contratuais . . . . . . . . . . . . . . . . 49

3.3.4 Busca e divisão de rendas . . . . . . . . . . . . . . . . 50

3.3.5 Divisão de $\operatorname{riscos} \ldots \ldots \ldots \ldots$. . . . . . . . . . . . . 51

3.4 Governança por meio dos mecanismos institucionais $\ldots \ldots \ldots$. . . . . . 52

3.4.1 Mecanismos formais . . . . . . . . . . . . . . 52

3.4.1.1 Estratégia de litígio . . . . . . . . . . . 52

3.4.2 As instituições privadas de governança . . . . . . . . . . . . . . 54

3.4.3 Mecanismos informais .................. 55

3.4.3.1 Comunidade, ou a organização informal . . . . . . . . . 58

3.4.3.2 As redes sociais . . . . . . . . . . . . 58

3.4.3.3 Confiança ....................... 59

4 O ambiente institucional brasileiro $\quad 61$

4.1 Caracterização do ambiente institucional brasileiro . . . . . . . . . . . . 61

4.1.1 Especificidades institucionais ............... 63

4.1.2 Especificidades culturais . . . . . . . . . . . . 65

4.1.3 Especificidades organizacionais ................. 66

5 Metodologia da pesquisa $\quad 67$

5.1 Problemática de pesquisa . . . . . . . . . . . . 67

5.1 .1 Questão de pesquisa .................... 67

5.1 .2 Objetivos de pesquisa . . . . . . . . . . . 68

5.2 Estratégia metodológica . . . . . . . . . . . . . 68

5.2.1 Análise de conteúdo ... . . . . . . . . . . . . 69

5.2.2 Análise comparativa . . . . . . . . . . . . . 70

5.2.3 Validação das análises . . . . . . . . . . . . . 71

6 Análise $\quad 72$ 
6.1 Contextualização do modelo eSCM . . . . . . . . . . . . . . . 72

6.1.1 Membresia do ITSqc Research Consortium . . . . . . . . . . . . . . . 72

6.2 Descrição do modelo eSCM . . . . . . . . . . . . . . . 74

6.2.1 Práticas e áreas de capacidade . . . . . . . . . . . . . . . . . . . 74

6.2 .2 Ciclo de vida . . . . . . . . . . . . . . . . . 82

6.2.2.1 Em andamento . . . . . . . . . . . . . 82

6.2.2.2 Análise . . . . . . . . . . . . . . . 82

6.2 .2 .3 Iniciação . . . . . . . . . . . . . . . . . . . 82

6.2 .2 .4 Entrega ....................... 83

6.2.2.5 Encerramento .................. 83

6.2 .3 Níveis de capacidade . . . . . . . . . . . . . . . . . 83

6.3 Relação do eSCM com outros modelos . . . . . . . . . . . . . . . . . . 83

6.4 Práticas selecionadas . . . . . . . . . . . . . . . . . . . . . 84

6.4.1 Sourcing Strategy Management _............... . 85

6.4.1.1 STR01 - Sourcing sponsorship . . . . . . . . . . 86

6.4.1.2 STR02 - Sourcing Constraints . . . . . . . . . 86

6.4.1.3 STR03 - Potential sourcing areas . . . . . . . . . . 87

6.4.1.4 STR04-Sourcing objectives . . . . . . . . . . . 88

6.4.1.5 STR05 - Organizational Sourcing Strategy . . . . . . . . . . 89

6.4.2 Governance Management . . . . . . . . . . . . . . . . 89

6.4.2.1 GOV01 - Sourcing Policy . . . . . . . . . . . . . . . 90

6.4.2.2 GOV02 - Service Provider Management . . . . . . . . . . 91

6.4.2.3 GOV03 - Internal Stakeholder Management . . . . . . . . . 91

6.4.2.4 GOV04 - Defined Sourcing Processes . . . . . . . . . . . . 92

6.4.2.5 GOV05 - Align Strategy \& Architectures . . . . . . . . . . . 92

6.4.2.6 GOV06 - Business Process Integration . . . . . . . . . . . . 93 
6.4.2.7 GOV07 - Adapt to business Change . . . . . . . . . . . 94

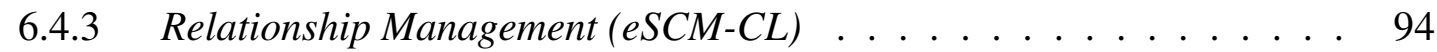

6.4.3.1 REL01 - Service provider interactions . . . . . . . . . . 95

6.4.3.2 REL02 - Service Provider Relationships . . . . . . . . . . 95

6.4.3.3 REL03 - Internal Relationships . . . . . . . . . . . . . 96

6.4.3.4 REL04 - Issue Management . . . . . . . . . . . . . . 96

6.4.3.5 REL05 - Cultural Fit . . . . . . . . . . . . . 97

6.4.3.6 REL06 - Collaborative Relationships . . . . . . . . . . . . 98

6.4.3.7 REL07 - Innovative Relationships . . . . . . . . . . . . 98

6.5 Análise de conteúdo do modelo eSCM . . . . . . . . . . . . . . . . . . 99

6.5.1 Análise da estrutura textual . . . . . . . . . . . . . . 99

6.5 .2 Análise categorial . . . . . . . . . . . . . . . 101

6.5.2.1 Planejar ....................... 101

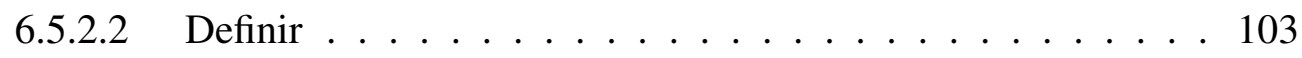

6.5.2.3 Mapear..................... 105

6.5.2.4 Documentar ................... 106

6.5.2.5 Verificar .................... 107

6.5.2.6 Revisar . . . . . . . . . . . . . . 107

6.5.3 Análise das premissas explícitas do modelo eSCM . . . . . . . . . 108

6.5.4 Análise das premissas implícitas no modelo eSCM . . . . . . . . . . 110

6.6 Análise comparativa do eSCM com o ambiente institucional brasileiro . . . . . 113

6.7 Validação das análises . . . . . . . . . . . . . . . . . . . . 117

6.7.1 Caracterização dos especialistas . . . . . . . . . . . . . 117

6.7.2 Validação do modelo cultural . . . . . . . . . . . . . . . . . . 117

6.7.3 Validação do modelo eSCM . . . . . . . . . . . . . . . . . 121

6.7.4 Validação das análises das premissas do modelo eSCM . . . . . . . . . 122 
6.8 Síntese das análises . . . . . . . . . . . . . . . . . . . . . . 128

7 Conclusão 130

7.1 O novo contexto . . . . . . . . . . . . . . . . 130

7.2 Mecanismos de governança . . . . . . . . . . . . . . . . . 130

7.3 Conclusões da pesquisa $\ldots \ldots \ldots \ldots$. . . . . . . . . . . . . . 132

7.4 Recomendações para pesquisas futuras . . . . . . . . . . . . . . . . . 136 


\section{LISTA DE TABELAS}

$1 \quad$ Fatores de risco no sourcing de TI. Adaptado de Aubert, Patry e Rivard (2005) . 25

2 Dimensões e componentes da confiança. Adaptado de Adler (2001). . . . . . . 60

3 Sumário dos traços de brasileiros, de Freitas (1997) . . . . . . . . . . . . . . 62

$4 \quad$ Modelo de especificidades do ambiente empresarial brasileiro. . . . . . . . . . . 64

5 Práticas do modelo eSCM-SP . . . . . . . . . . . . . . . . . . 74

6 Práticas do modelo eSCM-CL . . . . . . . . . . . . . . . 78

7 Comparação dentre o eSCM-SP v2 e a norma ISO 9001:20001 . . . . . . . . . 84

8 Relação das unidades semânticas encontradas na análise categorial das práticas selecionadas do eSCM. . . . . . . . . . . . . . . . . . . . . . . . 102

9 Comparação entre as unidades semânticas identificadas na análise categorial do eSCM e as etapas do ciclo PDCA. . . . . . . . . . . . . . . . . . . 108

10 Comparação entre as premissas identificadas na análise de conteúdo do eSCM e as especificidades do ambiente institucional associadas. . . . . . . . . . . . . 114

11 Influência cultural nas diversas fases do sourcing. Elaborado com base na entrevista com B. . . . . . . . . . . . . . . . . . . . . . . . . 119

12 Síntese das análises. . . . . . . . . . . . . . . . . . . . . . . 129 


\section{INTRODUÇÃO}

\subsection{Exposição do assunto}

A tecnologia da informação (TI) ocupa papel central no funcionamento das organizações contemporâneas. Em razão dessa centralidade sua gestão ganha cada vez mais destaque. Dentre os diversos aspectos associados com a gestão da TI, o fornecimento (sourcing) de serviços ganha ênfase crescente.

Historicamente, os serviços de TI e a unidade organizacional responsável pelo seu fornecimento (Centro de Processamento de Dados, Departamento de Informática, etc) se confundiam. Todos os serviços eram prestados a partir de recursos próprios, o uso de recursos externos era limitado. Contudo, no ínicio dos anos 1990 começaram a ocorrer mudanças nesse cenário.

Em 1989 a Kodak Inc firmou acordo com a IBM e a EDS para que estas responsabilissasem-se por todos os serviços de TI anteriormente prestados pelo departamento de informática da Kodak. Esse foi o início da tendência de contratação de fornecedores externos (em inglês outsourcing) que perdurou durante a década de 1990. A adoção exponencial dessa prática gerou vários casos de sucessos, e, também, um número maior de fracassos.

A expansão e diversificação do uso de fornecedores externos de serviços de TI propiciou a emergência de novos e complexos arranjos de governança com resultados, por vezes, distintos.

Os primeiros estudos acadêmicos concentraram-se na análise do fornecimento de serviços de TI como uma questão de estrutura firma, uma decisão entre fazer ou comprar (make-or-buy), caracterizando, assim, o sourcing como um problema de otimização da relação custo-benefício entre fazer internamente ou comprar no mercado.

Logo verificou-se a existência de outros problemas gerenciais associados, sobretudo, com desenvolvimento de mecanismos de incentivos para contornar problemas de assimetrias de informação entre fornecedores e clientes (por exemplo, qualidade de produtos e serviços, shirking, poaching, entre outros).

A solução para essas questões foi o desenvolvimento de novos arranjo institucionais de produção. O fornecimento de serviços mudou da prática de contratação de um único fornecedor externo (total outsourcing) para vários fornecedores (multisourcing). Com o fracasso obtido nas primeiras iniciativas, algumas empresas internalizaram o fornecimento de serviços de TI (backsource), contudo passaram a implementar competição interna entre as equipes de TI para fornecimento de determinados serviços (insourcing). 
Na pressão constante pela redução de custos, algumas organizações decidiram contratar fornecedores de serviços localizados em países com menor custo, como Índia, Brasil, etc, iniciando assim o movimento de contratação de fornecedores internacionais (offshore outsourcing). Mais recentemente, com o desenvolvimento das tecnologias colaborativas via Internet, começa-se a publicar anúncios de ofertas em comunidades web (crowdsourcing).

O surgimento de novos arranjos é motivado pela possibilidade de maximização de determinadas competências locais, associadas com uma redução dos custos totais da operação de sourcing. Por exemplo, o desenvolvimento de capital humano em TI, especificamente em desenvolvimento, tornou a Índia um forte atrator de companhias de tecnologia que montaram naquele país bases para atendimento global de desenvolvimento de software, assim contratos que outrora eram firmados com companhias locais passaram a ser feitos com companhias indianas, ou companhias multinacionais com operações na Índia; a informatização de alguns processos de negócio como compensação, processamento de transações de cartão eletrônico, call center tem permitido que as empresas terceirizem toda a cadeia de processo, passando a controlar apenas os resultados.

A inovação no sourcing não limita-se aos arranjos, o processo de contratação, também, tem evoluído. Do contrato de compra e venda simples (spot contract) aos contratos relacionais de longo-prazo, tem-se buscado novas formas de distribuição de lucros e risco entre as partes, novos mecanismos de encerramento do contrato, mas, sobretudo, uma consideração maior do relacionamento. Em um mercado grande, mas com poucos fornecedores o desenvolvimento de elementos de confiança e reputacionais sobrepujam, por vezes, o próprio contrato.

Concomitantemente, representantes de fornecedores, clientes e meio acadêmico buscam integrarse para o desenvolvimento de padrões de melhores práticas de contratação e gestão. O resultado tem sido o desenvolvimento de modelos de processos a serem implantados tanto nas organizações clientes quanto fornecedores. O discurso associado a esses padrões é de que os mesmos promovem o aumento da eficiência do sourcing ao eliminar redundâncias de processos e padronização das práticas.

Corroborou para o surgimento dessas práticas, no início dos anos 2000, vários escândalos envolvendo fraudes corporativas, os quais motivaram a criação de novos mecanismos de controle. O mais conhecido destes foi a lei norte-americana Sarbannes-Oxley Act, a qual dispunhas novos procedimentos para liberação de informações contábeis pelas companhias de capital aberto que operassem nas bolsas de valores norte-americanas.

Ainda que tal lei versasse primariamente sobre assuntos contábeis, também teve impacto sobre a gestão da TI. Passou a exigir-se controles mais efetivos e transparentes, contribuindo para o 
surgimento ou consolidação de recomendações de melhores práticas para a gestão de TI, assim com o surgimento de um mercado de certificações.

A despeito das suas especificidades, essas recomendações estão baseadas em princípios do movimento de Qualidade Total, surgido no Japão na década de 1980. Se esses primeiras recomendações buscavam abrangir toda a gestão de TI, logo surgiram modelos para funções específicas da gestão de TI. Destacam-se modelos para diversas atividades, como:

1. Controles de TI - COBIT (Control OBjectives for Information Technology);

2. Gerenciamento de infra-estrutura - ITIL (Information Technology Infrastructure Library);

3. Gerenciamento de projetos - PMBoK (Project Management Book of Knowledge);

4. Governança de sourcing - eSCM (eSourcing Capability Model).

A adoção desses modelos na gestão do sourcing ainda encontra-se nos primeiros estágios, contudo é uma tendência crescente. Acompanhando essa tendência, a literatura está focada no processo de adoção de tais metodologias.

Transpassando-se a literatura da área de sistemas de informação para a área de administração geral, encontra uma grande diversidade de estudos que versam sobre a adoção de recomendações de gestão ou sobre a adoção de modelos de governança corporativas.

Assim, como na literatura de sistemas de informação parte expressiva dos estudos enfoca o processo de adoção dessas recomendações. Entretanto, um número crescente de trabalhos questiona as ideologias e pressupostos subjacentes à esses modelos, assim como sua adequação às realidades instituicionais das organizações que estão os adotando. Esse tipo de questionamento, na literatura de sistemas de informação, sobre a adequação das recomendações sobre governança de fornecimento de serviços de TI é escassa.

A argumentação subjacente à essas recomendações é de que a padronização de processos diminua o risco associado com o uso de fornecedores externos. Implicitamente argumenta-se que uma mesma prática seja adotada de maneira similar por pessoas e organizações situadas em contextos econômicos, institucionais e culturais distintos, e, portanto, atingindo-se o mesmo resultado em diferentes contextos. Afirmações mais específicas sobre a natureza do processo de transferência de melhores práticas de governança de sourcing é limitada pela escassez de literatura científica sobre o tema.

Paralelamente, a globalização das atividades econômicas aumentam as pressões competitivas sobre as organizações, e por consequiência uma busca por arranjos de gestão mais efetivos. Se 
por um lado, a competição por arranjos alternativos é crescente (GORDON; ROE, 2004), por outro verifica-se também uma convergência dos arranjos de gestão para um modelo dominante internacionalmente (WHITLEY, 1999; DAVIS; STEIL, 2001; BECHT; BOLTON; RÖELL, 2002; CUERVO, 2002; MALLIN, 2002; ZATTONI; CUOMO, 2008). Ainda que seja observada a convergência para um modelo dominante, influenciada pela globalização dos mercados financeiros, pela homogeneização da preferência dos consumidores e da rápida mudança tecnológica (WOOD; BREWSTER, 2002), observa-se, também, a persistência de especificidades nacionais nas estruturas de gestão.

Sob a perspectiva dos mercados concorrências perfeitos, tais persistências podem ser vistas como uma aberração temporária, resultada da confluência de imperfeições de mercado, em um movimento inevitável rumo à homogeneidade global baseada na democracia liberar e na economia dos livres mercados (FUKUYAMA, 2000).

Na perspectiva institucionalista, argumenta-se que distintas nações possuem trajetórias distintas do desenvolvimento capitalista, nas quais ocorrem, inevitavelmente, variações na maneira em que os mercados e outros arranjos institucionais operam (HOLLINGSWORTH; BOYER, 1997; WHITLEY, 1999, 2000).

Essas variações específicas do capitalismo manifestam-se de forma intensa nos arranjos de gestão das organizações, uma vez que estes buscam determinar um conjunto de melhores práticas ou recomendações visando padronizar os processos com fins a um aumento de eficiência (ZATTONI; CUOMO, 2008).

É importante considerar que cada arranjo de gestão reflete um conjunto de fatores tais como as diferenças culturais, as opções de financiamento, a estrutura da firma e as origens legais (ZATTONI; CUOMO, 2008). Essas características, dentro de um determinado contexto, são resultado de um conjunto de forças que visam o aumento da eficiência e a legitimização dos efeitos dessa dependência do caminho (GORDON; ROE, 2004).

Assim, a despeito dos possíveis benefícios das adoção das práticas de governança e da pressão exercida pela globalização, a mudança nos modelos de governança não é um processo fácil pois tais estruturas estão incorporadas (embedded) no ambiente institucional (NORTH, 1990; WHITLEY, 1999; AOKI, 2001). Além disso a alta complementariedade entre os mecanismos de governança pode dificultar a convergência pois (1) alterar um mecanismo sem alterar os demais pode dissipar os benefícios obtidos pela interação entre eles (ZATTONI; CUOMO, 2008); (2) transformar várias instituições de forma simultânea e coordenada é um processo complexo (BEBCHUK; ROE, 1999; SCHMIDT; SPINDLER, 2002).

Alterar as prática de gestão pode requerer alterar políticas corporativas ou mesmo esbarrar em 
questionamentos legais. De fato, os modelos de governança possuem efeitos distribucionais, e criam grupos de interesses que apoiam o status quo (ZATTONI; CUOMO, 2008). O grupo atual pode resitir à introdução de um novo modelo de governança se isso ameaçar o controle dos benefícios privados desse grupo (RHODES; APELDOORN, 1998; BEBCHUK; ROE, 1999).

Desse modo compreender a importância relativa e impacto das instituições no processo de interação e trocas sociais constitui um dos grandes desafios das Ciências Sociais contemporâneas ${ }^{1}$. A compreensão dessa dinâmica é particularmente crítica em um país como o Brasil, no qual os fatores humanos e sociais moldam a prática gerencial.

Nesta pesquisa optou-se por analisar o modelo eSCM (eSourcing Capability Model), buscando compreender como suas premissas podem influenciar sua implementação no contexto brasileiro.

\subsection{Estrutura do trabalho}

Para alcançar essa proposta o trabalho foi estruturado em sete capítulos, incluindo a introdução. No capítulo 2 é discutida a governança de fornecimento de serviços de TI. Debate-se algumas questões críticas como gerenciamento de risco, arranjo contratual e compartilhamento de conhecimento. O capítulo é encerrado com uma apresentação dos principais modelos para governança de sourcing existentes no mercado.

Os fundamentos teóricos dos mecanismos de governança são a base do capítulo 3. Apresentase os mecanismos de governança baseado no seu arranjo das instituições que os sustenta. Os mecanismos podem estar baseado nas instituições de mercado, na hierarquia, na lei ou nos valores comunitários.

Uma caracterização da cultura brasileira, com suas especificidades institucionais, organizacionais e cultura é mostrada no capítulo 4.

A discussão da questão de pesquisa e a estratégia metodológica baseada em análise de conteúdo e análise comparativa é mostrada no capítulo 5.

No capítulo 6 são feitas as análises propostas, em especial, são identificadas as premissas do modelo eSCM.

Conclusões são oferecidas no capítulo 7.

\footnotetext{
${ }^{1}$ Ver Abbel (2003), Streeck (2003), Hollingsworth (2003).
} 


\subsection{Contribuições}

Em relação aos resultados da pesquisa, duas contribuições são buscadas: teóricas e práticas.

A primeira é uma contribuição teórica. Para tanto, a pesquisa buscará contribuir para o entendimento do importância dos fatores econômicos, culturais e políticos no uso de padrões de processos de contratação e gestão de terceirização de serviços de tecnologia da informação.

A segunda forma de contribuição é prática. Os resultados do estudo deverão ser pertinentes a todas as organizações que estejam planejando ou em processo de implantação de padronização de processos de governança de terceirização de TI, no sentido de fornecer elementos que permitam avaliar a efetividade do uso dos modelos de padronização de processos e eventuais necessidades ao contexto institucional específico no qual estas empresas estão inseridas.

As primeiras discussões sobre os mecanismos de governança de sourcing foram publicadas em:

- SOARES, Hebbertt de Farias; REINHARD, Nicolau. Governança da terceirização de TI: uma contribuição teórica. In: ALBERTIN, Alberto; SANCHEZ, Otavio (Ed.). Outsourcing de TI: impactos, dilemas, discussões e casos reais. São Paulo: FGV, 2008. 


\section{GOVERNANÇA DO FORNECIMENTO DE SERVIÇOS}

A gestão das infra-estruturas de tecnologia da informação (TI) em um ambiente de negócios globalizado e dinâmico apresenta-se como um dos grandes desafios na gestão das organizações (BROWN; MAGILL, 1994). A coordenação dos diversos atores envolvidos na operação dessas infra-estruturas é um tema em desenvolvimento na literatura, especialmente o desenvolvimento de modelos baseados em lógicas relacionais e de integração (SAMBAMURTHY; ZMUD, 2000). Essa questão é ainda mais pertinente quando a TI, ou o seu departamento funcional, possuem a forma de uma unidade juridicamente autônoma ou está vinculada à organização por um elo contratual, como no caso das relações de terceirização (BEULEN; RIBBERS, 2002). Gerenciar as relações contratuais de fornecimento de serviços (Sourcing) ${ }^{1}$ vem adquirindo especial importância por duas razões. A primeira é que a tendência para uso de fornecedores externos é crescente. A segunda está associada à dificuldade de caracterização dos serviços de TI, que cresce em complexidade estrutural em função de inovações tecnológicas como virtualização, arquitetura orientada a serviços, mashup de sistemas, open source, etc.

Se nos idos dos anos 1980, o sourcing de TI era feito, predominantemente, por uma unidade funcional interna. Nos anos 1990 assistiu-se o fenômeno da externalização dessa atividade, por meio do início da prática de uso de fornecedores externos, chamada terceirização ou outsourcing. Nos anos 2000, esse fenômeno é intensificado e novos arranjos emergem para atender novas necessidades de negócio. Aparece, dentre outros, a terceirização internacional (offshore outsourcing), o uso de vários fornecedores simultaneamente (Multisourcing). A despeito das inovações tecnológicas, o desenvolvimento de parcerias e capital social, especialmente confiança, são aspectos essenciais para o sucesso da iniciativa de sourcing (KERN; WILLCOCKS, 2002). A interação entre uma crescente complexidade estrutural dos serviços, o surgimento de novos arranjos para o fornecimentos desses serviços e uma crescente ênfase no componente humano dessas transações geram um cenário que tende ao caos. Por essa razão, a comunidade de praticantes e acadêmica têm se voltado para o estudo da governança do sourcing de TI. Esse ainda é um campo recente e em desenvolvimento. Como destacam Beulen e Ribbers (2002), a maior parte da literatura enfatiza os estudos de viabilidade do sourcing ao invés da governança. Perunović e Pedersen (2007) realizaram uma revisão de vários autores e sintentizaram o processo de sourcing em cinco etapas: preparação, seleção de fornecedores, transição, gestão do relacionamento e reconsideração.

\footnotetext{
${ }^{1}$ A expressão 'sourcing' é usada, em língua inglesa, para referir-se ao que, em língua portuguesa, denominamos 'fornecimento de serviços'. No intercurso desta dissertação optou-se pela grafia em língua inglesa.
} 


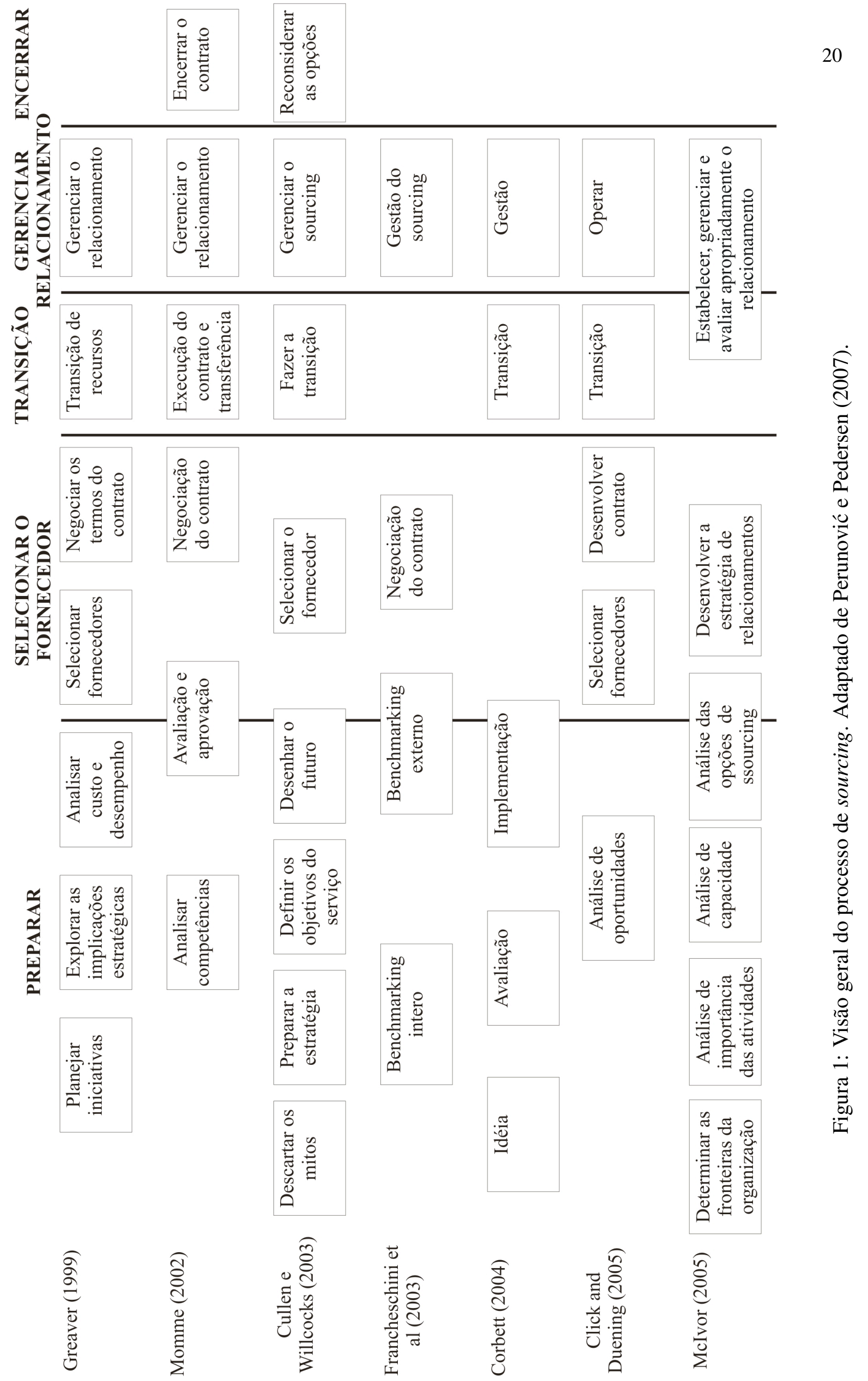




\subsection{Definindo a governança}

Beulen e Ribbers (2002), baseados na teoria de desenho organizacional de vertente Fayolista e em estudos de casos múltiplos em empresas européias, propõe que a governança de sourcing de serviços de TI possuem cinco fatores críticos de sucesso: estratégia de TI, gestão de informação, contratos, gestão de contratos, disponibilidade de recursos humanos. A estratégia de TI é compreendida como a visão de longo-prazo sobre como organização pretende otimizar o uso do sourcing de TI, baseado no alinhamento com a estratégias de negócio, e considerando aspectos como novos desenvolvimentos tecnológicos e novas oportunidades mercadológicas. No estudo de caso dos autores, seus informantes mostraram-se céticos com relação à qualidade da estratégias nas organizações estudadas. Para eles, os planos existentes refletiam muito mais um ajuste ao orçamento anual do que, propriamente, uma visão de longo prazo (BEULEN; RIBBERS, 2002).

A gestão da informação compreende as interfaces entre os processos de negócio do cliente e do fornecedor. Essa interface possui um papel central na coordenação da interação da iniciativa de sourcing. Contudo, ainda que os informantes unanimamente concorde sobre a importância dessa atividade, é, também, unânime o questionamento sobre como implementá-la (BEULEN; RIBBERS, 2002).

Os contratos são os componentes chaves da gestão do sourcing. Contudo, tais instrumentos jurídicos não substituem a confiança entre as partes. O contrato deve, concomitantemente, ser claro e flexível. As regras estipuladas devem permitir um entendimento comum do objeto, sem contudo, engessar a parceria (BEULEN; RIBBERS, 2002). A gestão dos contratos, na perspectiva de Beulen e Ribbers (2002), é a contra-parte, no fornecedor, do processo de gestão de informação. Consiste, essencialmente, na garantia do cumprimento das obrigações contratuais. A estrutura dessa atividade deve ser espelhada na estrutura de serviços do clientes, afim de estabelecer pontos de contatos claros e definidos. A incompletude dos contratos, em razão da racionalidade limitada dos agentes, leva a necessidade de renegociação do contrato, ou realização de termos aditivos. Em alguns casos, contudo, esse processo pode levar a conflitos ou mesmo a litígios (BEULEN; RIBBERS, 2003).

A disponibilidade de recursos humanos é o quinto fator elecando por Beulen e Ribbers (2002) como necessário para o sucesso do sourcing. A criticidade desse fator é decorrente da escassez de mão-de-obra qualificada no mercado. Assim, a gestão de recrutamento e turnover ganha destaque. 


\subsection{Questões associadas com a governança de sourcing}

\subsubsection{Arranjos contratuais}

Hefley e Loesche (2006, p. 7) elencam cinco grandes categorias de tipos de relacionamentos sob os quais o fornecimento de serviços de tecnologia da informação pode ocorrer.

1. Tradicional: um único fornecedor fornece serviços para um único cliente;

2. Co-sourcing: dois fornecedores trabalham em conjunto para entregar serviços para um único cliente. Freqüentemente um desses fornecedores é interno e o outro é externo;

3. Multi-sourcing: múltiplos fornecedores de serviços fornecem diversos serviços para um único cliente. O cliente assume a responsabilidade por gerenciar e integrar os vários fornecedores;

4. Aliança: múltiplos fornecedores colaboram entre si para atender um ou vários clientes. Frequientemente, um dos fornecedores tem o papel principal de representar a aliança junto ao cliente;

5. Joint venture: vários fornecedores de serviços, e em alguns casos o próprio cliente, juntam-se para criar uma nova empresa com a finalidade de prestar o serviço;

6. Insourcing: um grupo dentro do cliente é selecionado como o fornecedor de serviço, contudo é gerenciado como um fornecedor externo. Freqüentemente, esse grupo compete com fornecedores externos pela prestação de serviços. A expressão insourcing pode, também, referir-se a um centro de serviços compartilhados, localizado dentro ou fora da área geográfica do contratante. Nesse último caso, eles são denominados captive centers ou global delivery centers.

\subsubsection{Precificação e desempenho dos contratos}

Outro fator assaz importante na governança do fornecimento dos serviços de TI é a relação entre a precificação e o desempenho dos contratos. O trade-off entre preço e qualidade é o fator motivador para o estudo de Domberger, Fernandez e Fiebig (2000). Nesse trabalho os autores estudam a interação entre o preço e a qualidade de serviços de TI terceirizados.

O primeiro achado dos autores está associado com o efeito da competição. Verificou-se que os contratos de primeira rodada eram escolhidos através de processos de seleção competitivos, 
enquanto que os contratos seguintes eram estabelecidos por meio de negociação. Sugerindo, assim, que os clientes possuem preferência pela renovação das relacionamento. Contudo, essa diferença na forma de interação com o fornecedor não apresenta efeito sobre o preço dos contratos, uma vez que ambos possuíam preços similares (DOMBERGER; FERNANDEZ; FIEBIG, 2000).

Um segundo aspecto, é que o risco percebido pelo fornecedor é considerado na precificação dos contratos de sourcing de TI. Por exemplo, contratos renovados eram mais baratos do que o primeiro contrato, possivelmente, em função dos riscos associados com o primeiro contrato uma vez que o contratante não dispõe de um histórico de informações sobre o comportamento do cliente. Além disso, contratos baseados em disponibilidade de sistema comportavam um componente de prêmio para o risco de falha desses sistemas (DOMBERGER; FERNANDEZ; FIEBIG, 2000).

O modelo econométrico desenvolvido por Domberger, Fernandez e Fiebig (2000) sugere que a relação entre preço e qualidade do serviço é economicamente insignificante. Antes, a qualidade do serviço está associada com a especificação e com o estilo de gestão. Os autores reforçam que o resultado a iniciativa é dependente da gestão do relacionamento, especialmente do gerenciamento da lacuna entre as expectativas cumpridas e não-cumpridas.

\subsubsection{Riscos no sourcing}

Risco é a possibilidade de perdas decorrentes da exposição a um determinado evento, podendo ser calculado pela função de exposição ao risco

$$
E R=\sum_{i} p\left(E_{i}\right) \cdot d\left(E_{i}\right)
$$

Onde:

- ER é a exposição ao risco;

- $p\left(E_{i}\right)$ é a probabilidade de ocorrer o evento $i$

- $d\left(E_{i}\right)$ são as perdas do evento $i$.

O risco associado com o sourcing de TI é um dos fatores que impedem a expansão de novas formas dessa prática, com por exemplo a terceirização de processos de negócio (business process outsourcing) (ARON; CLEMONS; REDDI, 2005).

Aubert, Patry e Rivard (1998) classifica os possíveis eventos indesejáveis associados com o sourcing de TI em quatro categorias: custos ocultos, dificuldades contratuais, serviço e perda 
de competências organizacionais.

Aron, Clemons e Reddi (2005) classificam os riscos do sourcing em: riscos operacionais, isto é, aqueles riscos causados por falhas de sistemas ou equipamentos; risco de atrofia, quando a companhia perde as capacidades de TI; riscos intrínsecos, associado com fatores geográficos ou geopolíticos; mas, sobretudo, riscos estratégicos. Essa última classe de riscos são aquelas atividades causadas intencionalmente pelos fornecedores com a finalidade de explorar o cliente. Os autores subdividem os riscos estratégicos em três grupos:

1. Risco de não-execução do contrato ${ }^{2}$ - é o caso em que o fornecedor deliberadamente cobra integralmente pelo serviço, mas o executa apenas parcialmente ou em qualidade inferior;

2. Mal uso da informação - Uma parte considerável do sourcing de TI consiste no fornecimento de sistemas e/ou hospedagem de dados. Nesses casos, existe o risco de que o fornecedor utilize esses dados para outras finalidades;

3. Risco de quebra contratual oportunística - ocorrem quando o fornecedor descobre que o cliente não possui outra opção de fornecedor daquele serviço, passando, então, a usar o seu poder de barganhar para exigir renegociações contratuais.

\subsubsection{Compartilhamento de conhecimento}

A obtenção dos resultados esperados da iniciativa de sourcing requer a existência de competências complementares entre o fornecedor e o cliente. Em especial, eles devem ser capazes de compartilhar conhecimento e trabalhar como uma única equipe ainda que sejam duas organizações distintas.

Para compreender a interação que ocorre no processo de compartilhamento do conhecimento Bandyopadhyay e Pathak (2007) analisam o fenômeno sob a perspectiva da teoria dos jogos. O modelo considera dois empregados, $i$ e $j$, um da firma cliente e outro do fornecedor. Ambos precisam trabalhar em conjunto para entregar um novo produto ou serviço. Assume-se que o produto possui um custo marginal, para o trabalhador, de $m_{i}$, que é função do seu conhecimento $\tau_{i}$, decrescente com a sua quantidade de conhecimento.

$$
m_{i}=m_{i}\left(\tau_{i}\right) e m_{i \tau_{i}}<0
$$

\footnotetext{
${ }^{2}$ Vulgarmente chamado "corpo mole".
} 
Tabela 1: Fatores de risco no sourcing de TI. Adaptado de Aubert, Patry e Rivard (2005)

\begin{tabular}{|c|c|}
\hline Resultado não desejado & Fatores que geram o resultado \\
\hline Custos de transição e gestão & $\begin{array}{l}\text { Falta de experiência do cliente com a atividade } \\
\text { Falta de experiência do cliente com outsourcing } \\
\text { Incerteza sobre o ambiente legal }\end{array}$ \\
\hline $\begin{array}{l}\text { Custos de troca de fornecedor } \\
\text { (inclusive lock-in, repatriação } \\
\text { e transferência de fornecedor) }\end{array}$ & $\begin{array}{l}\text { Especificidade do ativo } \\
\text { Pequeno número de fornecedores } \\
\text { Escopo } \\
\text { Interdependência das atividades }\end{array}$ \\
\hline Custos de aditivos contratuais & $\begin{array}{l}\text { Incerteza } \\
\text { Descontinuidade tecnológica } \\
\text { Complexidade da tarefa }\end{array}$ \\
\hline Disputas e litígios & $\begin{array}{l}\text { Problemas de mensuração } \\
\text { Falta de experiência do cliente ou fornecedor com contratos } \\
\text { de sourcing } \\
\text { Incerteza sobre o ambiente legal } \\
\text { Pouco ajuste cultural }\end{array}$ \\
\hline Serviço & $\begin{array}{l}\text { Interdependência das atividades } \\
\text { Falta de experiência do fornecedor com a atividade } \\
\text { Tamanho do fornecedor } \\
\text { Estabilidade financeira do fornecedor } \\
\text { Problemas de mensuração } \\
\text { Complexidade da tarefa }\end{array}$ \\
\hline Aumento de custos & $\begin{array}{l}\text { Falta de experiência do cliente com gestão de contratos } \\
\text { Problemas de mensuração } \\
\text { Falta de experiência do fornecedor com a atividade }\end{array}$ \\
\hline $\begin{array}{l}\text { Perda de capacidades organi- } \\
\text { zacionais }\end{array}$ & $\begin{array}{l}\text { Escopo } \\
\text { Proximidade das core competences } \\
\text { Interdepedência das atividades }\end{array}$ \\
\hline Custos ocultos & $\begin{array}{l}\text { Complexidade das atividades } \\
\text { Problemas de mensuração } \\
\text { Incerteza }\end{array}$ \\
\hline
\end{tabular}


A quantidade de conhecimento de um funcionário depende do seu investimento $I_{i}$ na obtenção deste, assim como do grau de de conhecimento obtido pela troca com outros funcionários $(\sigma)$ e do grau de complementaridade do conhecimento dos dois funcionários $(\kappa)^{3}$. Assim, o conhecimento é modelado como:

$$
\tau_{i}=\tau_{i}\left(I_{i}, I_{j}, \sigma_{j}, \kappa\right)
$$

E a forma funcional de $\tau_{i}^{*}$ é dada por:

$$
\tau_{i}^{*}=I_{i}+\alpha_{i}\left(I_{i}, \kappa\right) \sigma_{j} I_{j}
$$

em que $\alpha_{i}$ é a fração do conhecimento de $j$ que $i$ é capaz de absorver, e depende tanto do seu esforço $I_{i}$ quanto da complementaridade do conhecimento $\kappa$.

Assumindo-se que $0 \leq \sigma \leq 1,0 \leq \alpha \leq 1,0 \leq \kappa \leq 1$, tem-se que a contribuição do conhecimento alheio nunca supera o tamanho do conhecimento próprio do indivíduo. Um aspecto a se notar é que se a complementaridade for alta, isto é, $\kappa \rightarrow 1$, isto é, os funcionários possuem conhecimentos muito distintos, o grau de absorção esse conhecimento tende a ser baixo, $\alpha_{\kappa}<0$. Por outro lado, o investimento no seu próprio conhecimento, aumenta o seu grau de absorção $\alpha_{I}>0$. Um fator importante é o custo da troca do conhecimento, $s\left(\sigma_{i}\right)$, que é crescente com o grau de troca, $s^{\prime}(\sigma)>0$.

O jogo de troca de conhecimento é modelado como um jogo de dois estágios. No primeiro estágio os jogadores decidem, cooperativamente ou não-cooperativamente, suas respectivas taxas de troca, $\left(\sigma_{i}, \sigma_{j}\right)$. Uma troca cooperativa significa que ambos os jogadores chegaram a um acordo sobre o nível de conhecimento a ser compartilhado. Por outro lado, na escolha não-cooperativa, cada jogador tem um $\sigma$ como melhor resposta à ação do outro. No segundo estágio, os jogadores decidem sobre o seu próprio investimento $\left(I_{i}, I_{j}\right)$.

Assumindo-se que no jogo não-cooperativo, ambos decidam por um nível $\sigma$ igual. E, no jogo cooperativo, também, consintam em $\sigma$. Assim, é possível resolver por backward induction.

Sabendo que o payoff de $i$ é dado por:

$$
\pi_{i}=\tau_{i}-m_{i}-I_{i}-s\left(\sigma_{i}\right)
$$

Assim, o jogador enfrenta um trade-off entre a quantidade de conhecimento que recebe nas interações com outros jogadores versus o custo de compartilhar o seu conhecimento ${ }^{4}$. Sabendo, também, que cada jogador busca maximizar seu payoff no segundo estágio. Tem-se, então dois

\footnotetext{
${ }^{3}$ A complementaridade é conceitualizada como o grau de disimilidade dos conhecimentos.

${ }^{4}$ Por questões de simplicidade, nesse jogo assume-se que o valor do produto a ser produzido é o próprio valor do conhecimento
} 
equilíbrios: quando os agentes cooperam e quando não-cooperam.

No caso do equilíbrio não-cooperativo o problema, no segundo estágio é dado por:

$$
\max _{I_{i}} g_{i}=\tau_{i}-m_{i}-I_{i}-s\left(\sigma_{i}\right)
$$

onde

$$
g_{i}=\alpha_{i}\left(I_{i}, \kappa\right) I_{j} \sigma_{j}-m_{i}\left(\tau_{i}\right)-s\left(\sigma_{i}\right)
$$

e

$$
I_{i}=I_{i}\left(\sigma_{i}, \sigma_{j}, \kappa\right) e I_{j}=I_{j}\left(\sigma_{i}, \sigma_{j}, \kappa\right)
$$

Como o nível de investimento é dependente do grau de cooperação e da complementaridade do conhecimento, então as condições de primeira ordem nos levam à:

$$
\frac{\partial g_{i}}{\partial I_{i}}=\alpha_{i I_{i}} I_{j} \sigma_{j}-m_{i \tau_{i}}\left(1+\alpha_{i I_{i}} I_{j} \sigma_{j}\right)=0
$$

Essa equação (2.9) implicitamente define que a função de reação de $i, I_{i}^{*}\left(I_{j}\right)$ como a melhor resposta para $I_{j}$, e de forma análoga para $j$. A interseção das duas reações leva o jogo para um equilíbrio de Nash não-cooperativo no segundo estágio $\left(I_{i}^{N C}, I_{j}^{N C}\right)$.

Como a solução é por backward induction, tem-se que no primeiro estágio do jogo não-cooperativo cada jogador otimiza o seu payoff pela escolha do $\sigma$ apropriado:

$$
\max _{\sigma_{i}} h_{i}=\alpha_{i}\left(\sigma_{i}, \sigma_{j}, \kappa\right) I_{j}^{N C}\left(\sigma_{i}, \sigma_{j}, \kappa\right) \sigma_{j}-m_{i}\left(\tau_{i}\right)-s\left(\sigma_{i}\right)
$$

Observando-se que

$$
\tau_{i}=I_{i}^{N C}\left(\sigma_{i}, \sigma_{j}, \kappa\right)+\alpha_{i}\left(I_{i}^{N C}\left(\left(\sigma_{i}, \sigma_{j}, \kappa\right) \sigma_{j} I_{j}^{N C}\left(\sigma_{i}, \sigma_{j}, \kappa\right)\right)\right)
$$

Expandindo a equação 2.11 e resolvendo para as condições de primeira ordem, resulta:

$$
\frac{\partial h_{i}}{\partial \sigma_{i}}=\sigma_{j}\left(\alpha_{i \alpha_{i}} I_{j}^{N C}+\alpha_{i} I_{j \sigma_{i}}^{N C}\right)-m_{i \tau_{i}}\left(I_{i \sigma_{i}}^{N C}+\sigma_{j}\left(\alpha_{i \sigma_{i}} I_{j}^{N C}+\alpha_{i} I_{j \sigma_{i}}^{N C}\right)\right)-s^{\prime}\left(\sigma_{i}\right)=0
$$

Como as funções de reação definem as melhores respostas para cada empregado no primeiro estágio jogo $\left(\sigma_{i}^{N C}, \sigma_{j}^{N C}\right)$. Então, o payoff de equilíbrio não-cooperativo pode ser obtido pela substituição dos valores de equilíbrio na função de payoff:

$$
h_{i}=h_{i}\left(\sigma_{i}^{N C}, \sigma_{j}^{N C}, \kappa\right)
$$


Como o equilíbrio é simétrico, então:

$$
\sigma_{i}^{N C}=\sigma_{j}^{N C}=\sigma^{N C}
$$

Implicando assim que:

$$
I_{i}^{N C}=I_{j}^{N C}=I^{N C}
$$

No caso do equilíbrio cooperativo, os jogadores decidem $\sigma$ em conjunto e decidem $I$ individualmente. Nesse novo jogo, no segundo estágio as condições de primeira ordem são as mesmas do caso anterior, exceto que $\sigma_{i}=\sigma_{j}=\sigma$ :

$$
\frac{\partial \tau_{i}}{\partial I_{i}}=\alpha_{i I_{i}} I_{j} \sigma-m_{i \tau_{i}}\left(1+\alpha_{i I_{i}} I_{j} \sigma\right)=0
$$

Por simetria, o equilíbrio de Nash é representado como:

$$
I_{i}^{C}(\sigma, \kappa)=I_{j}^{C}(\sigma, \kappa)=I^{C}(\sigma, \kappa)
$$

No primeiro estágio, os empregados decidem maximizar o seu payoff ao cooperar no nível apropriado de $\sigma$ :

$$
l=\alpha^{C}(\sigma, \kappa) I^{C}(\sigma, \kappa) \sigma-m_{i}\left(\tau_{i}\right)-s\left(\sigma_{i}\right)
$$

$\mathrm{e}$

$$
\frac{\partial l}{\partial \sigma}=\alpha^{C} I^{C}+\sigma\left(\alpha_{\sigma}^{C} I^{C}+\alpha^{C} I_{\sigma}^{C}\right)-m_{i}\left(\tau_{i}\right)\left(I_{\sigma}^{C}+\left(\alpha^{C} I^{C}+\sigma\left(\alpha_{\sigma}^{C} I^{C}+\alpha^{C} I_{\sigma}^{C}\right)\right)-s^{\prime}(\sigma)=0\right.
$$

A demonstração acima não é capaz de mostrar a quantidade de conhecimento compartilhada. Contudo, quando a complementaridade do conhecimento é grande, o payoff dos jogadores é maior quando decidem jogar cooperativamente. Em termos gerenciais, a implicação desse modelo é que quando uma firma decide terceirizar uma atividade, os funcionários das duas firmas precisam trabalhar em conjunto e compartilhar o máximo de informação possível. Como a tendência a cooperação não é natural, faz-se necessário o desenho de mecanismos de incentivo (BANDYOPADHYAY; PATHAK, 2007).

\subsection{Modelos para governança}

As necessidades de negócio de crescimento, adaptabilidade e controle de custos estão aumentando as preocupações dos gestores com as atividades de TI dentro das organizações. Para promover esses benefícios, uma série de padrões tem sido propostos nos últimos anos. Dentre 
esses modelos, destacam-se o COBIT, o ITIL e o eSCM.

O COBIT é um guia de gerenciamento enfocado nos mecanismos de controle e auditoria. Desenvolvido pela ISACA, constitui uma aplicação do ciclo PDCA à gestão de TI.

O ITIL é um conjunto de melhores práticas desenvolvidas para o serviço público inglês que prescreve a gestão de infra-estruturas.

O eSCM é um modelo voltado para o sourcing de serviços de TI. Engloba a versão para clientes e fornecedores.

Apesar os benefícios propostos tendem a ser top-down, distantes do trabalho real, ou de muito detalhadas, engessando os processos e não permitindo mudança para adaptação às necessidades do negócio (BAILEY et al., 2007).

Bailey et al. (2007) apontam que as abordagens existentes atualmente, especialmente as voltadas para o fornecimento de serviços, possuem diversas limitações, como:

- As abordagens de processos top-down limitam a descoberta e disseminação das melhores práticas locais;

- Os rígidos processos recomendados não são capazes de fornecer a flexibilidade necessária para descrever passos ad hoc e ações que são necessárias em um ambiente complexo e personalizado;

- É difícil para os praticantes adicionarem extensões ad hoc ou personalizações aos padrões;

- O reuso é limitado, pois apenas os processos de alto-nível, que são de conhecimento comum, são codificados, deixando solto os procedimentos, onde a expertise é realmente aplicada;

- Capturar as práticas requer planejamento e um esforço deliberado do administrador, e frequentemente ocorre apenas após o fato;

- A colaboração ocorre fora do ambiente de gestão, assim, discussões ad hoc não são preservadas junto com os artefatos associados;

- Encontrar expertise para um problema particular é difícil, pois as ferramentas não capturam, nem facilitam achar interações prévias com outros sistemas;

- A maior parte das ferramentas de gestão não são integradas. Desse modo, não é possível combinar e organizar os procedimentos por atividades; 
- Os ambientes integrados não conseguem preservar o contexto em que as aplicações de negócio funcionam. Assim, cada usuário precisa inicializar cada aplicação com informação do contexto;

- Não existe um modo fácil e preciso de contabilizar o esforço e tempo investidos nas atividades não-estruturadas. 


\section{MECANISMOS DE GOVERNANÇA}

\subsection{Introdução ao capítulo}

Como demonstrado no capítulo anterior, o problema da governança do sourcing de TI é, fundamentalmente, um problema de gestão de relacionamentos. Comporta a problemática do desenvolvimento de estruturas institucionais que induzam a coordenação e a cooperação entre cliente e fornecedor(es). Se no capítulo anterior discutiu-se a natureza do fenômeno, neste busca-se apresentar os modelos teóricos que explicam a governança.

Uma forma de introduzir essa discussão é por meio do problema da ação coletiva, por meio do jogo do dilema do prisioneiro. Na formulação original este jogo diz respeito a dois ladrões que foram presos pela polícia, com algumas evidências circunstanciais, mas nada definitivo. A polícia isola cada suspeito em uma sala e faz a cada um dos suspeitos a seguinte proposta: se ele confessar o roubo e seu parceiro não confessar, ele será libertado pela sua cooperação com a polícia, enquanto que seu parceiro ficará 10 anos na cadeia. Se o contrário acontecer, o parceiro confessar e ele não, ele ficará os 10 anos presos. Se ambos confessarem, ambos ficarão 8 anos na cadeia. Se nenhum confessar, ambos passarão 1 ano na cadeia, presos por vadiagem (FIANI, 2006). Representado na forma estratégica, esse jogo fica:

$$
\begin{array}{lrl|c|} 
& \multicolumn{2}{c}{\text { Prisioneiro B }} \\
& \multicolumn{1}{c}{\text { Nega }} & \multicolumn{1}{c}{\text { Confessa }} \\
\cline { 3 - 4 } \text { Prisioneiro A A } & \text { Nega } & -1 ;-1 & -10 ; 0 \\
\cline { 3 - 4 } & & 0 ;-10 & -8 ;-8 \\
\cline { 3 - 4 } & & &
\end{array}
$$

Como nesse jogo a decisão independe de cada jogador e não é coordenada ex-ante, o processo de interação estratégica produz um resultado ex-post, (confessa, confessa) que é dito inferior no critério de Pareto, já que o perfil de estratégias (nega, nega) produziria um resultado melhor para ambos os jogadores.

Se os jogadores no dilema do prisioneiro pudessem conversar entre si para faze um acordo de cumprimento obrigatório para ambas as partes, então, claramente eles conseguiriam obter o ótimo de Pareto inerente ao jogo.

Esse jogo foi transposto para a análise do problema sócio-econômico da degradação do meio ambiente, em razão do uso intensivo de um recurso escasso fornecido pela natureza, por Hardin (1982) e ficou conhecido com o problema da ação coletiva.

Ostrom (1990) ilustra essa questão por meio da existência de um pasto com uma capacidade máxima para $L$ cabeças de gado, e dois pastores. Assim, cada pastor pode ter até $\frac{L}{2}$ cabeças. Se 
ambos os pastores cooperam entre si obedecendo essa restrição, ambos obtém um retorno igual à 10 para cada. Se ambos não cooperam, obtêm um retorno nulo. Se um coopera e o outro não coopera, ou seja, superexplora o pasto, o primeiro tem um prejuízo de 1 e o segundo obtém um ganho de 11. Na forma estratégica esse jogo é representado como:

Pastor B

\begin{tabular}{lrl|c|} 
& & \multicolumn{1}{c}{ Coopera } & Não coopera \\
\cline { 3 - 4 } Pastor A & Coopera & $10 ; 10$ & $-1 ; 11$ \\
\cline { 3 - 3 } Não coopera & $11 ;-1$ & $0 ; 0$ \\
\cline { 3 - 4 } & &
\end{tabular}

Esse jogo não-cooperativo de informação imperfeita e completa tem um equilíbrio de estratégia dominante (não-coopera, não-coopera) que demanda algum tipo de solução.

A primeira possibilidade de solução é a intervenção estatal. A autoridade governante estuda e planeja o uso do pasto, e decide por estabelecer uma multa para a superexploração de, por exemplo, 2 unidades. Assim, a solução do jogo fica:

\begin{tabular}{r|c|c|}
\multicolumn{2}{c}{} & \multicolumn{2}{c}{ Pastor B } \\
\cline { 3 - 3 } Pastor A & Coopera & Não coopera \\
\cline { 3 - 3 } Cõo coopera & $10 ; 10$ & $-1 ; 9$ \\
\cline { 2 - 3 } & $9 ;-1$ & $-2 ;-2$ \\
\cline { 3 - 3 } & &
\end{tabular}

A problema é resolvido, pois agora a estratégia dominante passa a ser (coopera, coopera). Contudo, essa solução supõe que o agente governamental dispõe de informação completa sobre o comportamento dos pastores, além de admitir que o Estado é bem informado, pressupõe também que ele monitora corretamente, sanciona na medida certa e que sua atuação não tem custos.

Tomando em consideração essas limitações, um novo jogo se apresenta. Supondo-se que a autoridade governamental tenha informação completa sobre a capacidade do pasto, mas informação incompleta sobre o comportamento dos pastores. Suponha-se, ainda, que o Estado vá punir a superexploração (não-cooperação) corretamente com probabilidade $y$ e deixe de fazê-lo com probabilidade $(1-y)$; e, adicionalmente, o Estado pode punir o pastor de forma errônea a cooperação com probabilidade $x$, e atue de forma correta com probabilidade $(1-x)$. Nesse caso, o jogo fica:

$$
\begin{array}{l|c|c|}
\multicolumn{2}{c}{} & \multicolumn{2}{c}{\text { Pastor B }} \\
\cline { 3 - 4 } \text { Pastor A } & \text { Coopera } & \text { Não coopera } \\
\cline { 3 - 4 } \text { Não coopera } & 10-2 x ; 10-2 x & -1-2 x ; 11-2 y \\
\cline { 3 - 4 } & 11-2 y ;-1-2 x & -2 y ;-2 y \\
\cline { 3 - 4 } & &
\end{array}
$$

Agora, mesmo se o Estado induza a um resultado certo, ou seja, se $(10-2 x>11-2 y)$ e se $(-1-2 x>-2 y)$, fica evidente o custo que ele impõe à sociedade civil dos pastores. 
Uma segunda solução possível para o problema dos pastores é a privatização. A propriedade comum é transformada em propriedade privada. O pasto é dividido em dois e cada parte é transformada em propriedades privadas. A situação não se configura mais como jogo nãocooperativo. A maximização do retorno de cada pastor numa perspectiva de longo prazo pode evitar a superexploração da natureza.

Ostrom (1990) critica essas duas soluções, a estatista e a privatista, pois ambas pressupõem que a mudança institucional seja produzida e imposta por uma autoridade exterior reificada, à semelhança do Leviatã. Para a autora, existem, muitas vezes, soluções endógenas à comunidade em consideração, mesmo se eleas são difíceis, consumidoras de tempo e conflituosas. Não se pod esquecer que o próprio mercado é um bem público, assim outros arranjos institucionais são possíveis.

Lichbach (1996) retoma a discussão de Olson (1971) sobre o problema da ação coletiva e propõe uma nova argumentação fundamentada em dois métodos: a ampliação das bases normativas ação social e a introdução das instituições na análise situacional.

Na busca de uma forma canônica para o problema da ação coletiva, Lichbach (1996) sugere um modelo que considere o contexto em que existem $n$ potenciais cooperadores na produção de um bem público qualquer. Supondo-se que a seguinte função de utilidade comum possa representar as condições subjetivas de suas decisões:

$$
U_{i}=\frac{b}{n} \sum_{j=1}^{n} k_{j}-c k_{i}
$$

Onde:

- $U_{i}$ é a utilidade do indivíduo $i$;

- $c$ é o custo da contribuição do individuo $i$ para a produção do bem público;

- $\frac{b}{n}$ é o benefício do indivíduo $i$ devido à contribuição de qualquer outro indivíduo para a produção do bem público;

- $k_{i}$ e $k_{j}$ são funções que assumem valor 0 se o indivíduo não coopera e 1 se coopera.

Adicionalmente, assumindo-se os pressupostos de que:

1. O retorno é de conhecimento comum;

2. A escolha é binária: coopera ou não coopera; 
3. O benefício é igual para todos;

4. O custo é o mesmo para todos;

5. Não é possível fazer um acordo de cumprimento obrigatório;

6. E que o jogo só tem uma rodada.

Então, fica definido um jogo de dilema de prisioneiros generalizados por meio de duas condições:

$$
U_{i}^{-}(m)>U_{i}^{+}(m+1)
$$

$\mathrm{e}$

$$
U_{i}^{-}(0)<U_{i}^{+}(n)
$$

Onde: $U_{i}^{-}(m)$ é o retorno de um jogador $i$ que não coopera, mas quando $m$ outros cooperam, e $U_{i}^{+}(m)$ é o retorno de um jogador $i$ que coopera quando $m$ jogadores outros cooperam.

Na função de utilidade apresenta na equação 3.2 verifica-se que o retorno do jogador não cooperador, quando $m$ outros cooperam, é maior do que o retorno do jogador cooperador na mesma situação em que $m$ outros cooperam, ou seja, é melhor ser um aproveitador (free-rider). Já a função de utilidade da equação 3.3 apresenta que quando ninguém coopera o retorno quando todos cooperam, ou seja, a cooperação é coletivamente vantajosa. Assim, esse jogo pode ser

\begin{tabular}{|c|c|c|c|c|}
\hline & 0 coopera & 1 coopera & 2 coopera & $n-1$ coopera \\
\hline & $n-1$ não coop. & $n-2$ não coop. & $n-3$ não coop. & 0 não coop. \\
\hline$i$ coopera & $\frac{b}{n}-c$ & $\frac{2 b}{n}-c$ & $\frac{3 b}{n}-c$ & $\frac{n b}{n}-c$ \\
\hline não coop. & 0 & $\frac{b}{n}$ & $\frac{2 b}{n}$ & $\frac{(n-1) b}{n}$ \\
\hline
\end{tabular}
representado como:

Se esse jogo é um dilema de prisioneiros generalizado, tem-se que a equação 3.2 implica que

$$
\frac{b}{n} m>\frac{b}{n}(m+1)-c \Rightarrow \frac{b}{n}<c
$$

Isto é, o benefício marginal privado é menor do que o custo marginal privado. Por outro lado, pela equação 3.3 tem se que

$$
0<\frac{b}{n} n-c \Rightarrow b>c
$$

ou seja, o benefício marginal social é maior do que o custo marginal privado. Podendo, assim, visualizar que arranjos sociais não-cooperativos levam à situações com resultados não-ótimos segundo o critério de Pareto, por exemplo, a insuficiente produção de bens públicos. Assim 
questiona-se se um dilema de prisioneiros generalizado, que produz conseqüências maléficas coletivas não intencionais, estaria ligado a um processo e não a um estado de ótimo social.

Lichbach (1996) aponta que esse problema de ação coletiva pode ser solucionado de quadro modos possíveis: mercado (jogo não-cooperativo), contrato (jogo cooperativo), comunidade (jogo funcionalista) e hierarquia (jogo de agente e principal).

O mercado é um modo de organização em que as interações sociais são mediadas pelas transações de bens ou serviços, as quais são encaradas como não-cooperativas.

O contrato refere-se a um modo de organização social instituído cooperativamente para atingir uma finalidade específica. Pois a cooperação na ação coletiva se torna voluntariamente compulsória para todos os que se comprometem no contrato.

A comunidade significa aqui um modo de organização social que é determinado pela existência de um sistema de valores comuns e tradicionais, e na qual os comportamentos são determinados pelas estruturas.

A hierarquia é um modo de organização social construído sob os princípios de comando e de exercício do poder e que define os subordinadores e subordinados.

Esses modos de organização podem ser dispostos segundo as dimensões deliberação individual e da constituição institucional. Na primeira dimensão, os modos podem ser planejados, isto é, decorrem da vontade e da consciência dos agentes, e não-planejados, quando são produtos não-deliberados ou espontâneos das ações dos agentes.

Na segunda dimensão, os modos podem ser atomistas, quando põem agregados sociais formados por indivíduos autônomos; ou holísticos, quando instituem um sistema social que prédetermina o comportamento individual.

\begin{tabular}{|c|c|c|}
\hline & Inst. não planejadas & Inst. planejadas \\
\hline & Mercado (recompensa) & Contrato (lei) \\
\hline & Comunidade (valores) & Hierarquia (poder) \\
\hline
\end{tabular}

No jogo com a solução comunitária, tem-se a seguinte solução para o o dilema de prisioneiros generalizado simplificado para o caso em que há apenas dois jogadores:

\begin{tabular}{|c|c|c|c|}
\hline & \multicolumn{2}{|c|}{ Jogador B } \\
\hline & & Coopera & Não coopera \\
\hline \multirow{2}{*}{ Jogador A } & Coopera & $b-c ; b-c$ & $\frac{b}{2}-c ; \frac{b}{2}$ \\
\hline & Não coopera & $\frac{b}{2} ; \frac{b}{2}-c$ & $0 ; 0$ \\
\hline
\end{tabular}

Por ser um jogo de dilema de prisioneiro, a estratégia dominante não é um ótimo de Pareto. Contudo, se os jogadores são membros de um mesmos grupo social, então cada um deles é 
capaz de formar suas expectativa sobre o comportamento dos outros com base em suas própria. Suponha-se que cada um atribua probabilidades às opções dos outros com base nesses expectativas, assim o jogo fica:

\begin{tabular}{l|c|c|}
\multicolumn{2}{c}{ Jogador B } \\
\cline { 3 - 3 } Jogador A & Coopera & \multicolumn{1}{c}{ Não coopera } \\
\cline { 3 - 4 } Não coopera & $p(b-c) ; p^{\prime}(b-c)$ & $(1-p)\left(\frac{b}{2}-c\right) ;\left(1-p^{\prime}\right)\left(\frac{b}{2}\right)$ \\
\cline { 2 - 3 } & $\left(1-p^{\prime}\right)\left(\frac{b}{2}\right) ;(1-p)\left(\frac{b}{2}-c\right)$ & $q ; q^{\prime}$ \\
\cline { 2 - 4 } & &
\end{tabular}

As decisões agora são baseadas em valores esperados. A ação de um depende do que ele espera da ação do outro. O jogador A, por exemplo, opta por cooperar se a esperança de retorno dessa ação supera a espera de retorno da ação de não-cooperar, ou seja:

$$
p(b-c)+(1-p)\left(\frac{b}{2}-c\right)>(1-q) \frac{b}{2} \Rightarrow \frac{b}{2}(p+q)>c
$$

Eis que essa suposição só se verifica se $p+q$ não forem pequenos, já que por suposição $\frac{b}{2}<c$.

Supondo, agora, que o sentimento de comunidade é profundo, o jogador A pensa que o jogador B sempre coopera se ele coopera, implicando assim que $p=1$; ademais, ele ainda assume que o jogador B não coopera se ele não coopera, de modo que $q=1$. O mesmo raciocínio é válido para o jogador B ( $p^{\prime}=1$ e $\left.q^{\prime}=1\right)$. Desse modo o resultado do jogo fica:

$$
\begin{aligned}
& \text { Jogador B }
\end{aligned}
$$

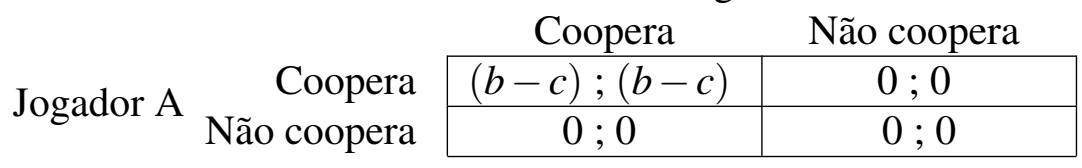

A comunidade que alinha as expectativas dos jogadores transforma o jogo de dilema do prisioneiro em um não jogo. Observe-se que a estratégia (cooperar, cooperar) é dominante por interação, o que permite eliminar a estratégia não-cooperar do jogo, e ao fazê-lo suprime-se o jogo enquanto tal.

Se a ação dos jogadores se ao sentimento de comunidade, este sentimento é o que explica ação dos jogadores. Nesse contexto, o que pensar pois acerca da afirma de Hayek (1985):

o comportamento racional não é, no entanto, uma premissa da teoria econômica, por mais que o apresente como tal. Ao contrário, a asserção básica da teoria é que a concorrência imporá às pessoas a necessidade de agir racionalmente para assegurar o próprio sustento.

Uma outra solução para o problema da ação coletiva é a solução contratualista. Baseada nos nos conceitos de auto-organização e de coletividade que governa a si própria, o que requer o 
desenho de instituições auto-regulatórias: convenções, padrões, contratos, etc. E envolvendo vários elementos como:

1. Os indivíduos têm de investir no planejamento e no arranjo de instituições estabilizadoras das relações sociais. Isto envolve negociação. Isto envolve, também, o estabelecimento de penalidades para os casos de violações das normas contratuais;

2. Os indivíduos têm de instituir formas de revisão de contratos;

3. como as normas são sempre algo ambígua e os contratos não são completos, há de existir algum sistema que permita resolver eventuais pendências e conflitos;

4. Os contratantes precisam encontrar formas de monitoramento do cumprimento das normas contratuais;

5. Os contratantes com um coletivo têm de ser capazes de garantir e obrigar o cumprimento dessas normas.

No estilo da teoria dos jogos, é possível pensar a alternativa contratualista como uma estratégia adicional que se agrega ao dilema do prisioneiro e que estabelece a possibilidade dos indivíduos participarem ou não do contrato.

\begin{tabular}{r|c|c|c|}
\multicolumn{3}{c}{ Jogador B } \\
Coopera & Não coopera & Contrata \\
\cline { 2 - 4 } Coopera & $b-c ; b-c$ & $\frac{b}{2}-c ; \frac{b}{2}$ & $\frac{b}{2}-c ; \frac{b}{2}$ \\
\cline { 2 - 4 } Jogador A Não coopera & $\frac{b}{2} ; \frac{b}{2}-c$ & $0 ; 0$ & $0 ; 0$ \\
\cline { 2 - 4 } Contrata & $\frac{b}{2} ; \frac{b}{2}-c$ & $0 ; 0$ & $b-c ; b-c$ \\
\cline { 2 - 4 } & & &
\end{tabular}

Este jogo misto de informação imperfeita e completa, não-cooperativo e cooperativo ao mesmo tempo, tem dois equilíbrios de Nash, um dos quais é melhor sob o critério de Pareto.

A solução por hierarquia busca obter cooperação por meio de alguma forma de centralização do poder, da criação de instituições que encarnam esse poder, o qual passa a se situar acima da coletividade, como se fosse algo exterior a ela. Pressupõe sempre a possibilidade de distinguir algum ou alguns como superiores entre iguais, de instituir uma hierarquia de decisão, de comando e de punição.

Em teoria de jogos essa situação é tratada genericamente como um jogo entre agente e principal, em que o primeiro, durante a vigência do contrato, subordina-se de algum modo ao segundo, mas tem melhor informação sobre o processo de execução do objeto contratado. Trata-se de um jogo caracterizado, sobretudo pela assimetria de informação. 
O exemplo clássico é ao contrato de trabalho. Este instrumento é realizado sob o pressuposto de qu eo empregado vai atuar de acordo com o interesse do patrão, mas o empregado, contraditoriamente, está obrigado pela própria natureza do sistema agir de acordo com o seu próprio interesse. E passar, assim, a ser chamado de oportunista, desonesto, desleal e explorador pelos economistas liberais.

Um exemplo desse jogo:

\begin{tabular}{lrl|c|}
\multicolumn{2}{c}{} & \multicolumn{2}{c}{ Agente } \\
\cline { 3 - 3 } Principal & Coopera & Não coopera \\
\cline { 3 - 3 } & Coopera & $10 ; 5$ & $8 ; 7$ \\
\cline { 3 - 3 } & Não coopera & $0 ; 0$ & $0 ; 0$ \\
\cline { 3 - 3 } & & &
\end{tabular}

A primeira jogada é sempre do Principal, escolhendo cooperar (assinar o contrato) ou não cooperar (não assinar o contrato). Se ele escolhe a segunda opção, o retorno do jogo é nulo para ambos. Se ele opta pela contratação, espera que o agente se esforce para atender estritamente aos termos do contrato. Nesse caso, o jogo teria um retorno de $(10 ; 5)$. Como o agente joga depois da assinatura do contrato, ele opta racionalmente pela não cooperação parcial, de tal modo que o retorno do jogo fica $(8 ; 7)$.

Assim, o equilíbrio perfeito de subjogo desse jogo de informação perfeita e completa, é o perfil de estratégia (Coopera ; Não coopera). Geralmente esse jogo é apresentado de forma mais sofisticada: o esforço do agente passa a depender das probabilidades introduzidas pela natureza; há monitoramento pelo principal, mas este, não sendo perfeito, passa a depender de probabilidades introduzidas pela natureza.

Esses modelos são particularmente interessantes pois nos apresentam diversas possibilidades teóricas para a solução do problema da governança. Nas seções seguinte, serão discutidas cada uma dessas abordagens em maior profundidade.

\subsection{Governança por meio dos mecanismos de mercado}

Compreender a governança pela perspectiva de mercado requer um entendimento do funcionamento destes. Para tanto, mister é aportarmos o instrumental da Teoria de Equilíbrio Geral e os seus fundamentos: a racionalidade dos sujeitos, a teoria do consumidor, a teoria da firma e o modelo de equilíbrio. 


\subsubsection{As preferências do consumidor e a racionalidade}

Inicialmente assume-se a existência de um conjunto de possibilidades $X$ o qual descreve todas as alternativas de escolha diponíveis para um indivídudo, em princípio, pode envolver quaisquer elementos ou objetos de decisão. Sob a perspectiva do consumir, o seu problema consiste em escolher as quantidades dos vários as quantidades dos vários bens e serviços disponíveis a serem adquiridos.

Assumindo-se que existe um número finito $L$ de mercadorias, cujas quantidades são representadas pelas variáveis $x$, com valor $x=1,2, \ldots, L$. Observando que uma mesma mercadoria pode ser consideradas mercadorias diferentes em função da sua disponibilidade no tempo e no espaço.

Posto essas colocações, a decisão do consumidor deve envolver a escolha dos bens e das quantidades destes que ele deseja consumir, isto é, um vetor em $R^{L}$ definido como:

$$
x=\left(x_{1}, x_{2}, \ldots, x_{L}\right)
$$

Considera-se que qualquer conjunto de possibilidades de consumo $X$, para qualquer consumidor, é sempre um subconjunto de $R^{L}$, ou seja $X \subset R^{L}$. Salvo os casos em que há menção em contrário, os conjuntos de possibilidades de consumo são definidos pelos subconjuntos das quantidades não-negativas $X=R_{+}^{L}$, ou seja:

$$
X=x=\left(x_{1}, x_{2}, \ldots, x_{L}\right) \mid x \subset R_{+}^{L}
$$

Posto essas definições sobre os bens, sobre eles estabelecem-se as relações de preferências dos indivíduos.

Uma relação de preferência $\succsim$ é uma relação binária de ordenação de preferências para um dado indivíduo, definida sobre o seu conjunto de possibilidades de consumo $X$, ou seja, para dois elementos $x$ e $y$, estabelece que:

$$
x \succsim y
$$

que é interpretada como o elemento $x$ é tão bom quanto o elemento $y$.

Sobre esta relação estabelecem-se dois axiomas básicos. O primeiro axioma refere-se a completude da relação. Assim, a relação é completa se para todos os conjuntos de possibilidade de consumo $x$ e $y \in X$ é possível afirmar:

$$
x \succsim y
$$


$\mathrm{ou}$

$$
y \succsim x
$$

ou ambos.

O segundo axioma diz respeito à transitividade da relação. Uma relação é dita transitiva se para todos os conjuntos de possibilidade de consumo $x$, ye $z \in X$ é possível afirmar que se:

$$
x \succsim y
$$

$\mathrm{e}$

$$
y \succsim z
$$

então

$$
x \succsim z
$$

Se uma relação atende ao axiomas de completude e transitividade, então a relação é racional. Analisando-se esses dois axiomas, verifica-se que eles encontram-se fora da realidade do indivíduo do quotidiano uma vez que o primeiro exige que um indivíduo normal seja capaz de ordenar quaisquer dois bens. No segundo, exige-se a consistência das comparações.

A relação de preferência pode ser representada sob a forma de uma função utilidade $u$ definida com domínio nas possibilidades de consumo $X$ e contra-domínio no conjunto dos números reais. A função $u$ é representativa da relação de preferência se:

$$
x \succsim y \Leftrightarrow u(x) \geq u(y)
$$

Diante do exposto o problema de tomada de decisão encontra-se na maximização da sua função utilidade. A formalização do problema de maximização da utilidade requer que seja assumido que para os $L$ bens existentes na economia existe um vetor de variáveis não-negativas $p=$ $\left(p_{1}, p_{2}, \ldots, p_{L}\right)$ que represente os preços, e que a renda do indivíduo seja representada pelo escalar $w$.

O gasto de um indivíduo com um determinado conjunto de possibilidades de consumo é dado por

$$
p \cdot x=\left(p_{1}, p_{2}, \ldots, p_{L}\right) \cdot\left(x_{1}, x_{2}, \ldots, x_{L}\right)=\sum_{l=1}^{L} p_{l} \cdot x_{l}
$$

Assim a equação de restrição orçamentária é dada por:

$$
p \cdot x \leq w
$$


Desse modo, o problema final de tomada de decisão do indivíduo, assumindo-se que ele possui uma relação de preferência que pode ser representada sob a forma de uma função utilidade, torna-se:

$$
\max _{x \geq 0} u(x), \text { s.a } x \in X \mid p \cdot x \leq w
$$

Assumindo-se que na economia existam $I$ indinvíduos, cada um deles dotado de uma relação de preferência racional e contínua $\succsim_{i}$, com correspondentes na relação de demanda $x_{i}\left(p_{i}, w_{i}\right)$, então a demanda agregada dessa economia é dada por

$$
x\left(p, w_{i}, w_{2}, \ldots, w_{I}\right)=\sum_{i=1}^{I} x_{i}\left(p, w_{i}\right)
$$

Considerando-se que essa relação não permite que de fato se possa trabalhar com a mesma em um modelo agregado, ou seja, onde os I indivíduos não são explicitamente considerados de forma individual, pode se questionar que sob quais condições pode-se garantir que $x\left(p, w_{i}, w_{2}, \ldots, w_{I}\right)=\sum I i=1 x_{i}\left(p, w_{i}\right)$ e assim desconsiderar os efeitos dos componentes individuais nessa economia? A resposta a esse questionamento é de que esse resultado só é possível, mantendo-se as condições restritivas sob as características comportamentais dos indivíduos.

\subsubsection{A firma na teoria clássica}

Se por um lado a teoria clássica ocupa-se de formalizar a perspectiva do consumidor, o mesmo o faz para as firmas e as atividades produtivas de uma economia. Assim, para uma economia com $L$ bens, existe um vetor $y=\left(y_{1}, y_{2}, \ldots, y_{L}\right)$ que descreve as quantidade líquidas das $L$ mercadorias que estão associadas a uma dada atividade de um processo produtivo.

Desse modo define um conjunto de produção, ou um conjunto de possibilidades de produção, $Y \subset$ $R^{L}$. Este representa o vetor de atividades viáveis tecnologicamente e disponíveis para a firma em um determinado momento do tempo. Essa é a caracterização da firma dentro da teoria clássica.

Assumindo-se que nessa economia exista um vetor de variáveis não-negativas $p=\left(p_{1}, p_{2}, \ldots, p_{L}\right)$ que represente os preços, o lucro obtido de um vetor de produção y é dado pelo produto escalar

$$
p \cdot y=\sum_{l=1}^{L} p_{l} y_{l}
$$

Diante disto, o único objetivo da firma é a maximização do seu lucro, e o seu comportamento 
nos mercados é determinado pela solução do problema de maximização dos lucros:

$$
\max _{y} p \cdot y, s . a y \in Y
$$

A partir desse problema, deriva-se a função lucro

$$
\pi(p)=\max p \cdot y \mid y \in Y
$$

Considerando-se que nessa economia existam $J$ firmas, cada uma com seu conjunto de produção $Y_{j}(j=1,2, \cdot, J)$. E adicionalmente, $\pi_{j}(p)$ e $y_{j}(p)$ representem, respectivamente, a função lucro e a oferta da firma $j$, então pode-se definir o conjunto agregado de produção dessa economia como:

$$
Y=\left\{y \in R^{L} \mid y=\sum_{j=1}^{J} y_{j}\right\}
$$

onde $y_{j} \in Y_{j}, j=1,2, \ldots, J$.

Supondo-se que exista uma entidade fictícia, conhecida na literatura econômica como "Planejador central”, para o qual é definido um problema de maximização do lucro como

$$
\max _{y} p \cdot y, \text { s.a } y \in Y
$$

E que a partir da solução desse problema, obtém-se a função de lucro e a correspondência da oferta do Planejador Central

$$
\begin{gathered}
\pi^{*}(p)=\max p \cdot y \mid y \in Y \\
y^{*}(p)=y \in Y \mid p \cdot y=\pi^{*}(p)
\end{gathered}
$$

Assim, para essa economia é possível demonstrar o teorema da agregação do comportamento das firmas, que para todos os vetores de preço $p>O$ tem-se que:

$$
\left.\pi^{*}(p)=\sum_{j=1}^{J} \pi_{(} p\right)
$$

e

$$
y^{*}(p)=\left\{\sum_{j=1}^{J} y_{j} \mid y_{j} \in y_{j}(p), j=1,2, \ldots, J\right\}
$$

O significado desse teorema é que numa economia com todos os mercados operando sob re- 
gras de competição perfeita, o comportamento agregado de um conjunto de firmas é o mesmo, independentemente do fato deste ser obtido como agregação de comportamentos individuais e independentes das firmas, ou como resultado da coordenação conjunta das ações destas mesmas firmas. E esse resultado é garantido com hipóteses muito pouco restritivas sobre os conjuntos de produção das firmas individuais.

\subsubsection{Equilíbrio geral competitivo}

O estabelecimento do equilíbrio geral competitivo pressupõe a existência de uma economia competitiva de propriedade privada. Para tanto, assume-se que exista uma economia $I$, positivo e finito, consumidores, representados pelo índice $i$; $J$, positivo e finito, firmas, representadas pelo índice $j$; e $L$, positivo e finito, bens e serviços, representados pelo índice $l$, onde valem os pressupostos anteriormente definidos para a relação de preferência dos consumidos e para conjunto de produção das firmas.

E adicionalmente, assume-se que cada agente econômico (consumidores e firmas) atua em cada um dos mercados dos $L$ bens e serviços de modo a atingir o máximo do seu próprio interesse (maximização das suas preferências e lucros, respectivamente), sob condições de competição perfeita, ou seja, com base em mecanismos de mercado onde esse agente é um tomador de preços (cada agente ajusta-se passivamente aos preços vigentes na economia, independentemente da possibilidade de que a sua ação possa afetar esses mesmos preços).

Assim sendo, as relações de preferencias, tecnologias, recursos disponíveis e dados sobre direitos de propriedade, ou seja, os chamados fundamentals de uma economia podem ser representados por

$$
\left\{X_{i}, \succsim_{i}\right\}_{i=1}^{I},\left\{Y_{j}\right\}_{j=1}^{J},\left\{\omega_{i}, \theta_{i 1}, \ldots, \theta_{i J}\right\}_{i=1}^{I}
$$

onde:

- $\omega$ é a dotação inicial de bens e serviços de cada consumidor $i, \operatorname{com} \omega_{i} \in R^{L}$;

- $\theta$ é a participação dos lucros de cada firma $j$, na proporção $\theta_{i j}$, onde $0 \leq \theta_{i j} \leq 1$.

O equilíbrio geral competitivo dessa economia constitui-se, se:

1. Para cada firma $j=1,2, \ldots, J$, a atividade $y_{j}^{*}$ maximiza o seu lucro com os preços $P$, ou seja,

$$
P y_{j}^{*} \geq P y_{j} \mid y_{j} \in Y_{j}
$$


2. Para cada consumidor $i=1,2, \ldots, I$, a cesta de consumo $x_{i}^{*}$ maximiza suas preferência aos preços $P$, ou seja,

$$
P x_{i}^{*} \leq W(p), x_{i}^{*} \succsim x_{i} \mid x_{i} \in X_{i}
$$

tal que

$$
P x_{i}^{*} \leq W(p) \text { onde } W(p)=P \omega_{i}+\sum_{j=1}^{J} \theta_{i j} P y_{j}^{*}
$$

3. Existe consistência entre as quantidades totais demandadas e ofertadas de cada bem $l=$ $1,2, \ldots, L$, ou seja

$$
z_{l}(P)=\sum_{i=1}^{I} x_{l i}^{*}-\sum_{i=1}^{I} \omega_{l i}^{*}-\sum_{j=1}^{J} y_{l j}^{*} \leq 0
$$

e

$$
z_{l}(P)=0, \forall P_{l}>0
$$

\subsection{Governança por meio dos mecanismos contratuais}

A despeito dos importantes resultados obtidos pelo modelo de equilíbrio geral competitivo, o mesmo sofre de limitações resultantes de sua própria racionalidade. No início dos anos 1930, crítica esse modelo por tomar a firma como sendo a unidade de análise. Para Commons (1924), a unidade de análise da teoria econômica deveria ser a transação (FARINA; AZEVEDO; SAES, 1997). Knight (1921) projeta-se no cenário econômico por fazer a distinção entre risco e incerteza ${ }^{1}$. Knight inicia um argumento de que o principal motivo para se entender a organização econômica é a redução de desperdício.

A grande contribuição, contudo, é de Coase (1937) ao propor que a coordenação, necessária ao funcionamento da economia, poderia ocorrer dentro das firmas. O impacto dessa abordagem é que a firma deixa de ser um somente um espaço de transformação, descrito por uma função de produção, para ser, também, um espaço de coordenação dos agentes econômicos (FARINA; AZEVEDO; SAES, 1997).

Formalmente, o argumento de Coase (1937) pode ser representado da seguinte forma: sejam $G_{i}$ e $G_{j}$ dois mecanismos alternativos de coordenação; e sejam $C_{i}$ e $C_{j}$ os custos dos respectivos mecanismos. Assim, $G_{i}$ é eficiente se

$$
C_{i} \leq C_{j}
$$

e, similarmente, $G_{j}$ é eficiente se

$$
C_{i} \geq C_{j}
$$

\footnotetext{
${ }^{1}$ Essa conceituação posteriormente iria influenciar largamente a Teoria Geral do Emprego, do Juro e do Dinheiro de John Maynard Keynes
} 
O argumento de Coase esteve a margem por quase 40 anos. É somente no final dos anos 1970 que ele volta a tona, trazendo consigo novos elementos como direitos de propriedade, estrutura organizacional e mecanismos de governança. O reflorescimento do modelo coasiano foi largamente influenciado por dois desenvolvimentos teóricos: o relaxamento dos pressupostos de informação perfeita e racionalidade.

O primeiro esboço foi feito no sentido de relaxar os pressupostos de informação perfeita, assumindo-se assim, a existência de assimetria de informação nas transações econômicas. Arrow (1968) estuda o problema de risco moral (moral hazard) no setor de seguros, e verifica a existência de comportamentos pós-contratuais oportunísticos de uma das partes que possui mais informação do que sua contra-parte. Esse comportamento distingue-se em informação oculta, nos casos em que a ação é verificável, mas a informação, não; e em ação oculta, em que as ações do agente, também, são ocultas.

Akerlof (1970) estuda o problema de seleção adversa, enfocado agora a assimetria de informação pré-contratual. Na seleção adversa, resumidamente, os vendedores de produto de boa qualidade são expulsos do mercado por não conseguirem convencer os compradores acerca da qualidade do seu produto.

Essas imperfeições de informação aumentam a incerteza das transações, inviabilizando assim, o sistema de preços, em função da complexidade. Para ele, o mecanismo fica além da compreensão da humana, pois

Drawing upon such contracts would be expensive, and understanding them would be equally so. The courts of law, on the basis of long experience, have shown little faith in the ability of the average individual to understand complicated contracts (ARROW, 1974, p. 35)

Nesse mesmo raciocínio, Herbert Simon (1959) crítica hiperracionalidade dos agentes econômicos imposta pela teoria de equilíbrio geral. Simon reconhece que embora o ser humano seja capaz de condicionar seu comportamento à razão, ele o faz de forma limitada. Consequentemente, os contratos elaborados para reger as transações são, também, limitados.

A partir desses desenvolvimentos, o argumento de Coase (1937) é retomado. Contudo, ainda não são claros os processos de surgimento das formas organizacionais e de seleção destas. Simon propõe dois modelos para a seleção das formas organizacionais: seleção por tentativa e erro; e seleção por experiência prévia.

Esses argumentos são retomados por um aluno de doutorado de Simon, Oliver Williamson. 


\subsubsection{Da firma ideal às formas híbridas}

A firma é um dos elementos centrais do capitalismo, e assim a compreensão de sua estrutura interna desempenha papel central na pesquisa. Contudo, ainda que a teoria da firma seja um dos construtos analíticos chaves sobre o qual a teoria microeconômica fundamenta-se (WILLIAMSON, 1991), na visão da economia clássica e neoclássica a firma representa um conjunto de unidades de produção o qual responde às iniciativas competitivas de acordo com a lei dos retornos decrescentes. No contexto onde o mercado é tido como o meio mais eficiente de organização das atividades econômicas, a firma é definida como uma caixa preta que responde diretamente às mudanças nos preços e nas pressões do mercado (HODGSON, 1998). A firma converte bens de entrada em bens de saída de acordo com sua função de produção e a demanda do mercado.

É necessário fazer uma distinção entre a firma do "mundo real"e a firma da teoria econômica. A confusão entre os dois conceitos pode levar a enganos, destaca Demsetz (1983). O objetivo da teoria neoclássica é entender como o sistema de preços coordena o uso dos recursos existentes na economia, e não o funcionamento interno das firmas reais.

A busca pela compreensão das formas organizacionais levou ao desenvolvimento da economia dos custos de transação (ECT). A inovação conceitual aporta foi a proposição do o estudo das hierarquias e mercados associada com a avaliação comparativa da eficiência dos alternativos modos de governança.

Apesar de os primeiros trabalhos sobre custos de transação aparecerem na década de 1930, é somente na metade dos anos 1970 que a ECT se torna influencial, a partir dos trabalhos de Arrow (1974)e, especialmente, os de Williamson (1971, 1975, 1979).

A origem da teoria dos custos de transação (TCT) é o artigo seminal de Coase (1937) sobre a natureza da firma, a partir dos trabalhos existentes sobre a importância da informação (ARROW, 1974), inovação organizacional (CHANDLER, 1973), custos de transação (COASE, 1937) e racionalidade limitada na tomada de decisão (SIMON, 1959), Williamson (1979) inicia uma análise sobre a integração vertical e a natureza da firma. O trabalho de Williamson (1975) resgata trabalhos anteriores e os sintetiza, permitindo uma nova leitura da teoria da firma. Dentre os antecendes que são resgatados destacam-se:

- Commons $(1924,1934)$ propôs que a transação econômica fosse a última unidade de análise da teoria econômica, além de chamar a atenção para o problema da transferência de controle legal e a eficâcia do processo de contratação; 
- Coase (1937) propôs a noção de custos de transação, isto é, os custos de utilizar o sistema de mercados. Esse custo influencia a forma de organização das transações e a estrutura das firmas;

- Hayek (1945) com a propriedade de adaptação do sistema de mercados, sobre condições de competição.

- literatura de falhas de mercado: mercados incompletos por causa de incerteza, problemas de securitização, relações laborais, integração vertical, mercado de capitais, retornos crescente e sunk costs, indivisibilidades, informação assimétrica, bens públicos e falta de definição de direitos de propriedade e externalidades com custo de transação positivo;

A estrutura de governança refere-se ao ambiente institucional no qual as transações econômicas são iniciadas, negociadas, monitoradas, adaptadas, executadas e encerradas (PALAY, 1984). Diversas estruturas podem co-existir. A teoria econômica tradicional distingue duas estruturas de governança: os mercados e as firmas. Por um lado, os mercados são baseados na oferta e demanda de bens, ajustados pelo sistema de preços. Por outro, as firmas, ou hierarquias, possuem a decisão interna e autônoma de alocação dos recursos.

Se pensarmos essas duas estruturas de governança como extremos de um contínuo, faz-se necessário reconhecer a existência de arranjos intermediários, que combinam aspectos dos dois extremos. Trata-se de arranjos de entidades legalmente autônomas, que realizam transações, e se ajustam sem a necessidade de uso do sistema de preços, realizando trocas de produtos, informações, capital e serviços sem uma hierarquia unificada (MÉNARD, 2004). Esses arranjos intermediários na linha do contínuo são formas híbridas de governança, sendo sua função primordial dar segurança e suporte às transações.

No caso da terceirização, podemos ver os diversos tipos de terceirização adotados pelas firmas como formas híbridas de governança, em alguns casos mais próximos de uma transação de compra e venda de mercado e em outros mais próximos de uma hierarquia.

Quais seriam, pois, os aspectos que reúnem essa variedade de arranjos de governança? Ménard (2004) chama a atenção para certas regularidades empíricas fundamentais, ou certas configurações, comuns. São elas o compartilhamento de recursos, a contratação e pressões competitivas. As formas híbridas de governança, independentemente de seu arranjo estrutural, estão voltadas para a cooperação entre firmas, fazendo-se necessário algum grau de planejamento conjunto das decisões de investimento (em ativos humanos, físicos, etc). Ménard (2004) elenca fatores associados com o compartilhamento de recursos: 
1. O compartilhamento de recursos abre margem para o surgimento de comportamento oportunístico das partes, assim a escolha do parceiro é central. Essa decisão deve considerar a identidade do parceiro e sua reputação;

2. A decomposição do planejamento das tarefas entre os parceiros e a coordenação através de firmas legalmente independentes são os fatores preponderantes na escolha do arranjo e dos mecanismos de monitoramento;

3. O compartilhamento de recursos entre firmas distintas e autônomas pressupõe uma continuidade da relação, o que requer o desenvolvimento de mecanismos de cooperação. Contudo, como pode o arranjo de governança escolhido aumentar a segurança da cooperação a um baixo custo, sem perder as vantagens das decisões descentralizadas (MÉNARD, 2004)? No caso da terceirização, como garantir o cumprimento de padrões de custo e qualidade, assim como alcançar objetivos de negócio, trabalhando com fornecedores distintos? E, sob a perspectiva do fornecedor, como reaproveitar investimentos feitos em uma certa parceria?

Teoricamente, o problema do compartilhamento de recursos pode ser solucionado pelo emprego de contratos formais detalhados. Contudo, o detalhamento dos contratos é custoso e mesmo impossível, dada as limitações cognitivas dos agentes. Além disso, as firmas envolvidas na parceria de terceirização são legalmente autônomas e, portanto, dotadas de autonomia sobre a alocação dos seus investimentos. Assim, os contratos funcionam mais como um quadro de referência para o funcionamento da parceria (LAFONTAINE; SLADE, 1997).

Dado um contrato que tem o objetivo de ser um quadro de referência (MACNEIL, 1974), torna-se crucial escolher um arranjo de governança adequado para complementá-lo, suprir suas lacunas, monitorar as partes e resolver disputas (MÉNARD, 2004). A questão que se coloca, então, é como tais arranjos podem dar segurança aos contratos face a (re)negociações custosas ou mesmo impossíveis?

Outro fator que determina o arranjo de governança a ser escolhido são as pressões competitivas às organizações estão submetidas. Ménard (2004) reforça que as pressões competitivas operam em dois sentidos: o primeiro é a competição entre os membros do acordo estabelecido; e o segundo é a competição entre os arranjos de governança. 


\subsubsection{Escolha da estrutura de governança}

Qual o arranjo institucional escolher para governar uma parceria de terceirização de serviços de TI? O trabalho de Ménard (2004) indica três dimensões que estão envolvidas nesta escolha: os riscos contratuais resultados do investimento conjunto e as incertezas associadas; proteção e distribuição ao longo do tempo dos ganhos (e perdas) gerados pelo arranjo; e a execução da promessa.

\subsubsection{Riscos contratuais}

Os contratos são promessas legalmente executáveis (MACNEIL, 1974). Nas economias de mercado eles são um dos principais mecanismos existentes para salvaguardar o interesse das partes dos riscos associados com as transações como dependência multilateral, problemas de mensuração, mudanças do ambiente, direitos de propriedade mal definidos ou fraquezas do ambiente institucional (WILLIAMSON, 1996; NORTH, 1991).

Os contratos possuem a função de aumentar a segurança das transações e, conseqüentemente, reduzir o seu custo. Assim, os contratos desempenham um papel fundamental para a coordenação dos arranjos híbridos. Ménard (2004) elenca cinco características que combinadas definem as propriedades fundamentais de um arranjo:

1. Escolha do número de partes a participarem do acordo - a escolha do número de partes está relacionada com o trade-off entre monitoramento e dependência. Um número menor de parceiros é mais fácil de monitorar, porém a organização contratante torna-se mais dependente; por outro lado, um número maior de parceiros aumenta os custos de monitoramento, mas permite realizar benchmarkings e comparações;

2. Duração - o tempo de duração da relação é outro aspecto importante na determinação da estrutura do arranjo. As evidências empíricas sugerem que as formas híbridas tendem a ser relacionamentos de longo-prazo, o que sugere que, quanto maior o tempo de duração, maior o investimento a ser realizado na coordenação das atividades;

3. Especificações - os contratos existentes nos arranjos híbridos especificam quantidade e, sobretudo, a qualidade dos serviços transacionados. A provisão de especificações além de diminuir os custos associados com o monitoramento do contrato, desempenha, também, um papel na coordenação dos atores uma vez que o sistema de preços não é suficientemente forte para restringir os agentes legalmente autônomos; 
4. Cláusulas de adaptação - assim como as especificações, as cláusulas de adaptação funcionam como mecanismos de contingência criados em face da impossibilidade de se utilizar o sistema de preços;

5. Outros mecanismos de salvaguarda - A despeito da importância dos elementos já citados se fazem necessários outros mecanismos para salvaguarda das partes. Estes podem ser formais, especificados em contratos, ou informais, baseado em reputação (KREPS; WILSON, 1982) ou confiança (AXELROD, 1984).

O uso de outros mecanismos de salvaguarda frente aos contratos formais na terceirização de serviços de TI é analisado empiricamente por Poppo e Zenger (2002). Seus resultados apontam que esses mecanismos de coordenação funcionam como complementos no gerenciamento da relação. Em especial, os autores verificam que, por um lado, os gerentes adotam os mecanismos informais na medida em que a relação contratual é adaptada, aumentando, assim, a dependência mútua e o risco inerente. Por outro lado, o aumento do uso de mecanismos informais gera um aumento de complexidade dos dispositivos contratuais.

\subsubsection{Busca e divisão de rendas}

Uma das premissas inerentes à análise econômica é a busca da maximização do lucro pelos agentes econômicos, gerando problemas de busca de renda (rent seeking) e divisão de rendas. Ambos os fenômenos aumentam o nível de risco e, conseqüentemente, alteram o arranjo de governança da transação.

Obviamente, ao entrarem em uma parceria, as firmas esperam extrair rendas dos seus investimentos. Neste cenário, os contratos especificam as regras para distribuir os ganhos (e perdas) resultantes das ações conjuntas, contudo a possibilidade de não poder reutilizar os investimentos realizados para uma parceria abrem espaço para um oportunismo que os contratos não podem antecipar nem monitorar (MÉNARD, 2004).

O centro do problema reside na existência de direitos de propriedade autônomos (MÉNARD, 2004), isto é, as partes envolvidas no acordo possuem direitos autônomos de uso dos ativos, capacidade para mudar sua forma e substância, assim como a prerrogativa de apropriar-se dos retornos deles obtidos (ALCHIAN, 1987).

Uma vez que a apropriação de rendas é um dos fatores motivadores da criação dos arranjos híbridos, como evitar oportunismos pós-contratuais na sua apropriação? Ménard (2004) aponta três mecanismos que frequentemente aparecem na literatura como solução: 
1. reputação, isto é, a repetição das transações permite formar um juízo acerca das práticas adotadas pelas partes, influenciando, assim, nas decisões futuras;

2. dispositivos de negociação criados para decidir sobre a distribuição de rendas residuais;

3. e a determinação de um comitê conjunto dotado de autoridade formal para a tomada de decisão.

\subsubsection{Divisão de riscos}

A divisão dos riscos é um dos problemas de incentivos na formação dos contratos. O risco pode ser estudado isoladamente como fator determinante da forma contratual ou em conjunção com outras variáveis.

Ackerberg e Botticini (2000) analisam o fato de que na Toscana, Itália, durante o século XVIV o uso de contratos de troca (share contracts) foi o principal arranjo de governança das transações agrícolas, de forma antagônica ao cenário que ocorria nos outros países europeus da época. Os autores testam três hipotéses:

1. Hipótese de divisão de riscos - Nos tempos de falta de emprego, seguidos pela Peste Negra, os senhores feudais usavam esses contratos para atrair os camponeses pobres, e portanto avesos ao risco, ao oferecer-lhes um seguro parcial contra as variações no resultado das colheitas;

2. Hipótese de risco moral de multitarefa - O contrato de trocas era um contrato ótimo, pois garantia simultaneamente um incentivo a produção e proteção contra abusos do senhor feudal, além das plantações permanentes, criação de gado e uso das ferramentas do senhor feudal;

3. Hipótese de mercado de capital imperfeito - Na ausência de um mercado de capital, empréstimos e ferramentas eram emprestados pelo senhor feudal aos camponeses pobres em troca de trabalho, uma que estes não possuíam colateral para pegar esses empréstimos no mercado aberto.

Os resultados suportam as duas últimas hipóteses.

Em um contexto em que os agentes possuem a mesma preferência ao risco, mas onde os mercados de capitais são imperfeitos, o agente com maior acesso ao crédito pode se comportar como se fosse avesso ao risco (ESWARAN; KOTWAL, 1985). Como diferentes empresas tem diferentes 
formas de acesso ao crédito (empréstimo bancário, abertura de capital, capital próprio, etc), esse aspecto acaba influenciando a distribuição de risco na relação contratual de sourcing de TI, tanto pela perspectiva do cliente quanto pela perspectiva do fornecedor.

Uma crítica a esses modelos é que sejam muito simplificados, não conseguindo captar as diversas nuances da percepção do risco pelos agentes dentro de diferentes contextos (AGGARWAL, 2007).

\subsection{Governança por meio dos mecanismos institucionais}

A maior parte dos modelos contratuais existente na literatura assumem que as partes podem estabelecer contratos que delineam claramente os direitos e obrigações de cada parte para cada contingência possível. Contudo, no mundo real os contratos não funcionam dessa maneira, são, ao contrário, incompletos (AGGARWAL, 2007). Apesar disso, as organizações continuam funcionando. Essa lacuna dos contratos é suprida por outros mecanismos: as instituições.

A governança por mecanismos institucionais deve considerar dois facetas: os mecanismos formais e os mecanismos informais.

\subsubsection{Mecanismos formais}

\subsubsection{Estratégia de litígio}

Em um ambiente institucional onde exista a capacidade de execução dos contratos por meio do sistema jurídico, existem, pelo menos três estratégias de litígio (FINKLE, 2004).

Finkle (2004) na sua tese de doutorado expõe o seguinte modelo de estratégias de litígio. Suponha-se que uma firma é controlada por um único principal, neutro ao risco. O principal contrata um agente, também neutro ao risco, para gerenciar essa firma. O resultado $q$ dessa firma é verificável é valorado de acordo com uma função estritamente côncava $V(q)$.

O agente possui informação sobre o seu custo marginal de produção, $\theta$, o qual pode ter dois valores $\theta \in\left\{\theta_{L}, \theta_{H}\right\}, \theta_{L}<\theta_{H}$. O agente aceita um custo de produção de $\theta_{q}$. O principal não conhece o conhece o custo de produção do agente, mas acredita que $\mathbb{P}\left(\theta_{H}\right)=p$.

Quando o agente conhece seu custo marginal, o principal oferece um contrato do tipo aceitarou-largar especificando um conjunto de resultados $\left(q_{i}\right)$ e pagamentos $\left(t_{i}\right),\left\{q_{i}, t_{i}\right\}_{i=H, L}$. O agente pode cumprir o contrato e produzir $q_{i}$ e receber o pagamento de $t_{i}$ quando seu custo marginal $\theta_{i}$. A outra opção do agente é não-cumprir o contrato e produzir $q_{j \neq i}$ e receber $t_{j \neq i}$. 
Após analisar o resultado da produção, ter pago o agente, o principal descobre que o agente não cumpriu o contrato e resolve processá-lo. Assumindo o caso em que o agente superfaturou os seus custos para produzir $q_{H}$.

No processo de litígio, ambas as partes envolvem esforços para ganhar o caso por meio da contratação de advogados, recolhimento de provas, testemunhas, etc. Esse esforço é representado por $l$. Neste caso, o principal, que é o acusador, possui um esforço com custo médio e custo marginal de $l_{P}=1$. De forma análoga, o agente, que é o réu, possui um nível de esforço dado por $l_{A}^{i}, i=H, L$. O custo do agente depende do mérito do caso, se ele sabe que é culpado terá um custo maior do que se ele souber que cumpriu fielmente o contrato. No primeiro caso $l_{A}=1$, e no outro $\mu_{A}>1$.

O efeito de cada esforço no processo de litígio é dado por uma função de sucesso do litígio, dado por:

$$
\sigma\left(l_{P}, l_{A}^{i}\right)=\frac{l_{P}}{l_{P}+l_{A}^{i}}, i=H, L
$$

onde $\sigma(\cdot)$ é a probabilidade que o acusador ganhe o litígio. Sabe-se que o sistema jurídico e o juiz são atores neutros desse jogo.

Um outro aspecto a ser considerado no processo de litígio é o custo de fraude $\lambda$, isto é, os custos do agente e do principal, caso um deles tenha cometido uma frade, em manter a fraude oculta. Também é necessário considerar os custos processuais $S$, se o acusador ganha, o réu tem que pagar os custos processuais do acusador, assim $S>0$. Se o réu ganha, o principal deve pagar apenas o devido pagamento ao réu.

Assumindo-se que o jogo ocorre na seguinte sequiência:

1. O agente aprende o seu custo de produção;

2. O principal oferece o contrato;

3. O agente escolhe a quantidade que produzirá;

4. O resultado $q_{i}$ é observado, e $t_{i}$ é pago;

5. Se $q_{H}$ é produzido, então, o principal inicia um litígio;

6. Se o processo é iniciado, ambos devem ter esforços de litígio;

7. Quando o resultado sai, se o principal ganha, o agente tem que lhe pagar $S$. 
Detalhando-se o processo de litígio, tem-se que, em equilíbrio, o agente terá um esforço de litígio que minimize o seu custo, ao passo que o principal terá o seu custo ótimo. Tomando $\alpha$ como o conhecimento ex-post do principal de que o agente possui $\theta_{L}$, sendo que ele havia informado que possuía $\theta_{H}$. Assim, a função objetiva do principal fica:

$$
\max _{l_{P}} S \alpha \frac{l_{P}}{l_{P}+l_{A}^{H}}+S(1-\alpha) \frac{l_{P}}{l_{P}+l_{A}^{L}}-l_{P}
$$

Ao passo que o agente com baixo custo vai ter uma função objetiva

$$
\min _{l_{A}^{L}} S \frac{l_{P}}{l_{P}+l_{A}^{L}}+\mu l_{A}^{L}
$$

e o agente de alto custo

$$
\min _{l_{A}^{H}} S \frac{l_{P}}{l_{P}+l_{A}^{H}}+\mu l_{A}^{H}
$$

As funções objetivas dos agentes possuem solução interior

$$
l_{A}^{H}=\sqrt{S l_{P}}-l_{P}
$$

e

$$
l_{A}^{L}=\sqrt{\frac{S l_{P}}{\mu}}-l_{P}
$$

Essas soluções mostram que tanto o principal quanto o agente de alto risco empenharam níveis de esforços estritamente positivos, ao passo que o agente de baixo custo terá um esforço positivo somente se $l_{P}<\frac{S}{\mu}$.

\subsubsection{As instituições privadas de governança}

Tradicionalmente a literatura do campo de Economia das Organizações trabalhou com a dicotomia entre o ambiente institucional - as regras e crenças, formais e informais, que criam a identidade de uma nação (grupo, sociedade, etc) (NORTH, 1991) - e o arranjo institucional - o qual refere-se às estruturas de governança e aos arranjos contratuais de um conjunto de transações (WILLIAMSON, 1996, 1985)

Desenvolvimentos recentes desses modelos apontam a necessidade de consideração do conjunto de elementos normativos que existem no intermédio. Brousseau e Raynaud (2006) denominam esses elementos de instituições privadas. Trata-se de mecanismos organizados voluntariamente para organizar processos de coordenação e cooperação coletivos, em última instância esses 
dispositivos correspondem a processos de auto-regulação.

No caso dos arranjos híbridos, a dependência mútua, característica necessária para a continuidade da relação e conseqüente extração de rendas, somada a incertezas no ambiente institucional e a incompletude dos contratos favorecem o surgimento de instituições privadas visando a implementação de um ordenamento privado de governança das transações.

A governança privada das transações, em contraposição à governança baseada exclusivamente no ordenamento proveniente de fontes públicas, mostra a existência de mecanismos de autoridades, distintos do comando hierárquico, que funcionam como o elemento central das estruturas híbridas de governança (MÉNARD, 2004).

Esse mecanismo é dotado de um poder com diversos graus de formalização. Visto no extremo de um contínuo, existem arranjos baseados em confiança, próximo das relações de mercado, e, no outro extremo, arranjos com alto grau de formalização, próximos da estrutura hierárquica de uma firma (MÉNARD, 2004).

\subsubsection{Mecanismos informais}

No processo de desenvolvimento nacional, os países precisam desenvolver dois conjuntos de instituições: instituições que reduzam os custos de transação e promovam a confiança, e instituições que influenciem o Estado a proteger a propriedade privada (SHIRLEY, 2003). O primeiro grupo incluem os contratos, e os mecanismos de garantia (enforcement) dos contratos, normais e regras comerciais, hábitos e crenças que favoreçam valores compartilhados e acumulação de capital humano. No segundo grupo, estão os sistemas jurídicos formais como as constituições, leis civis e outros.

$\mathrm{Na}$ ausência dessas instituições, os indivíduos e as organizações são defrontados com o risco de não obter o retorno dos seus investimentos em razão da impossibilidade do Estado de garantia dos direitos de propriedade. As conseqüências são o refreamento do investimento, baixa produtividade e estagnação econômica (SHIRLEY, 2003).

Shirley (2003) faz uma revisão da literatura sobre relação entre desenvolvimento econômico e o baixo desenvolvimento institucional de alguns países, e argumenta a existência de quatro razões básicas:

- Herança colonial - os países herdaram instituições fracas de seus colonizadores;

- Herança colonial plus - os países possuíam reservas de recursos naturais ou pessoas que podiam ser escravizadas, incentivando os colonizadores a explorar essas riquezas; 
- Conflito político - os países tinham pouco ou nenhum conflito nas suas fronteiras ou entre suas elites, permitindo aos legisladores criarem leis que beneficiassem seus próprios interesses;

- Crenças e normas - os países possuíam crenças e normas inóspitas à atividade econômica ou promoviam a desconfiança para com aqueles que praticam essa atividade, dificultando assim o desenvolvimento de instituições que fortalecessem a atividade econômica;

Dentre os determinantes do desenvolvimento econômico estão incluídos os valores religiosos, hábitos, e cultura, definida por North (1994) como a transferência intergeneracional de normas, valores e idéias que funciona como um determinante da dependência do caminho das atividades econômicas. North (1994) destaca que a cultura não é estática, mas o importante é compreender o processo de aprendizado pelo qual a cultura muda que importa.

Greif (1994) analisa a influência das instituições sobre a atividade econômica naquilo que ele denomina de "crenças culturais" (cultural beliefs), isto é, as idéias e pensamentos comuns a um grupo de individuos que governam as transações econômicas e as relações sociais entre si e com outros grupos. Greif (1994) ilustra seu argumento com a comparação dos mercados cristão italianos e os judeus magribis. Esses tinham uma estrutura social horizontal assentada em parcerias e "amizades formais". Nesse sistema a reputação e o medo do ostracismo funcionava como um mecanismo de barganha. Observa-se que nesse grupo social não ocorreu o desenvolvimento de contratos formais e tribunais e o comércio ficava restrito aos membros do grupo social.

Por outro lado, na sociedade cristã italiana do século XVI desenvolveu-se uma estrutura social vertical na qual notas promissórias (lading bills), contratos formais, e cortes permanentes desenvolveram um papel central na barganha entre os mercadores e a conseqüente expansão da atividade mercantil.

Shirley (2003) destaca que os mecanismos formais e informais de suporte à cooperação não são exclusivos. Ao contrário, eles funcionam de forma complementar e reenforçando um ao outro. Nesse sentido, Putnam, Leonardi e Nanetti (1993) tentam mostrar que o desenvolvimento econômico da Itália contemporânea está associado com as redes de associação que promovem confiança entre estrangeiros e nativos - também chamado de capital social -, afim de solucionar problemas coletivos e conseqüentemente melhor desempenho econômico.

Ao passo que parte da teoria social está focada na busca de estruturas - ou instituições - que dão suporte a atividade econômica, outra vertente argumenta que o comportamento dos agentes econômicos e as instituições estão intensamente constrangidas pelas relações sociais que analisá-los independentemente constitui um erro de grandes proporções (GRANOVETTER, 1985, 
p. 482). Granovetter (1985) aporta à sociologia econômica a análise da incorporação social (social embeddedness) da ação econômica.

O argumento da incorporação social é fundamentado na tese de que as relações sociais - mais do que as instituições ou a moralidade - são as principais responsáveis pela produção da confiança na atividade econômica (GRANOVETTER, 1985, p. 491). Em um trabalho recente Granovetter (2005) expõe que as estruturas sociais, sobretudo as redes sociais, são importantes para a atividade econômica por alterar o fluxo e qualidade da informação, ser uma fonte de recompensas e punição, além de ser um mecanismo de suporte ao desenvolvimento de confiança entre os agentes econômicos.

Granovetter (1992) expõe que as instituições não emergem automaticamente em resposta às necessidades econômicas. Pelo contrário, elas são construídas pelos agentes cuja ação é facilitada ou constragida pelas estruturas e recursos disponíveis na rede social em que eles estão incorporados.

Ruijter e Weesie (2007) analisam um tipo de terceirização no qual a confiança desempenha um papel central na mitigação do risco: a terceirização de serviços domésticos. A despeito da particularidade do tema, o risco é um elemente presente nesta transação por duas razões. A primeira é pela diferença de conhecimento entre os agentes, o que abre espaço para oportunismo por parte do fornecedor do serviço (prestar um serviço de qualidade inferior, aumentar o preço pelo serviço, etc). E, segundo, pelo fato de o locus do serviço ser o domić́lio, a esfera privada, do contratante, e em geral, em horário que o contratante não se encontra, criando assim incentivos para outros comportamentos oportunistas (roubo, danos materiais, trabalho devagar, etc). Nesse cenário a confiança entre as partes desempenha um papel central na mitigação do risco.

Nessa linha de argumentação, Zylbersztajn e Lazzarini (2005) analisam o processo de licenciamento de sementes de milhos e verificam que a taxa de terminação dos contratos diminui com resultados passados satisfatórios, sugerindo que as partes aumentam o valor da relação ao longo do tempo. Por outro lado, as relações contratuais estão sujeitas a severidade conforme elas se desenvolvem. Aparentemente, destacam os autores, o valor do contrato diminui ao longo do tempo em função da obsolescência da tecnologia ou por que os licensiados se tornam mais aptos a expropriar a tecnologia sendo trocada.

A vasta literatura sobre escolha do contrato tem sido dirigida por duas questões básicas: (1) Por que existem variedades de contratos, e (2) por que essa variedade de contratos é (ou não) eficiente? A distribuição do risco é uma das respostas para a existência da diversidade e distribuição dos diversos tipos de contratos, uma vez que desenvolvem fatores redutores de risco e proporcionam a redução dos custos de transação (CHEUNG, 1969). Outra perspectiva relacionada é a 
redução do risco moral ou de shirking na presença de colonos aversos ao risco (STIGLITZ, 1974).

\subsubsection{Comunidade, ou a organização informal}

No processo de desagregação das organizações, verifica-se o surgimento de várias firmas interligadas entre si por relações em forma de rede. Surge um espaço interorganizacional com características hibrídas do mercado e da hierarquia, mas, também, com fortes laços sociais e informais, baseados na confiança (ADLER, 2001).

O termo comunidade é ambíguo. Aqui é empregado para referir-se à organização informal que existe, paralelamente, às estruturas formais da organização (ADLER, 2001).

\subsubsection{As redes sociais}

Essas forma de estruturação da organização e das relações entre organizações está baseada em laços econômicos, legais, técnicos, sociais e administrativos, fracos ou fortes (GRANOVETTER, 1973), que definem padrões de relacionamento (GUMMESSON, 2001a). Na sua estruturação estão envolvidos fatores econômicos e não-econômicos (EASTON; ARAUJO, 1992; WELLMAN; BERKOWITZ, 1988).

As redes também são vistas como combinações de atores, atividades e recursos os quais são interconectados com os processos e relações de troca (GUMMESSON, 2001a; FORD, 2002); ou membros de um grupo que partilham interesses comuns e formam uma comunidade (GUMMESSON, 2001b).

Jones, Hesterly e Borgatti (1997) analisam as definições de rede existente na literatura e apontam que as diversas definições estão concentradas em torno de dois conceitos:

1. padrões de interação nas trocas e relacionamentos;

2. fuxo de recursos entre unidades independentes. Buscando combinar esses dois elementos, os autores propõem que a governança das redes envolve um grupo seleto, persistente e estruturado de firmas autônomas engajadas na criação de produtos ou serviços baseados em contratos implícitos ou abertos (open-ended) com a finalidade de adpatar as contingências ambientais e coordenar e salvaguardas as relações de trocas (JONES; HESTERLY; BORGATTI, 1997, p. 914).

Elo (2003) afirma que as parcerias estabalecidas dentro de uma rede não são transações únicas 
(one-off transactions), mas processos de trocas sendo continuamente influenciados pela mudança e ajuste entre as partes.

Os relacionamentos entre empresas são afetados por um grande conjunto de fatores. A significância e complexidade dos fatores pode ser analisada pelas distâncias existentes entre os participantes: distância física, distância econômica, distância educacional e distância cultural (ELO, 2003, p. 5).

Diederen e Jonkers (2001) observam que um "um pressuposto básico sobre os relacionamentos em rede é que uma parte é dependente dos recursos controlados por outra, e que os ganhos obtidos são resultados do compartilhamento de recursos (pooling of resources)". Os autores adicionam "que as redes são caracterizadas por propriedades específicas da transação, tipificadas por relacionamentos relacionais nos quais os mecanismos de troca e confiança, tanto formais quanto informais, são cruciais".

As posições acima mencionadas reenforçam uma das premissas assumidas pelo autor: a necessidade de uma perspectiva multidisciplinar para a compreensão da relação entre o risco e a governança no contexto de fornecimento de serviços.

Ao longo dessa revisão bibliográfica buscou-se desenvolver uma perspectiva holística dos elementos que contribuem para a governança de terceirização de serviços de TI. Buscou-se encontrar fundamentos nos trabalhos da economia, sociologia, administração e sistemas de informação.

\subsubsection{Confiança}

A confiança é o mecanismo de coordenação das organizações informais 
Tabela 2: Dimensões e componentes da confiança. Adaptado de Adler (2001).

\begin{tabular}{|l|l|}
\hline DIMENSÃO & COMPONENTE \\
\hline Fontes & $\begin{array}{l}\text { Familiaridade por meio de interações repetidas } \\
\text { Cálculo baseado em interesses } \\
\text { Normas que criam confiança e predibilidade }\end{array}$ \\
\hline Mecanismos & $\begin{array}{l}\text { Contato direto interpessoal } \\
\text { Reputação } \\
\text { Contexto institucional }\end{array}$ \\
\hline Objetos & $\begin{array}{l}\text { Indivíduos } \\
\text { Sistemas } \\
\text { Coletividades }\end{array}$ \\
\hline Bases & $\begin{array}{l}\text { Consistência, confiança contratual } \\
\text { Competência } \\
\text { Benevolência, lealdade, compromisso, boas intenções, confiança fiduciária } \\
\text { Honestidade, integridade } \\
\text { Abertura }\end{array}$ \\
\hline
\end{tabular}




\section{O AMBIENTE INSTITUCIONAL BRASILEIRO}

A influência da cultura na economia e na administração das organizações é um dos temas de crescente interesse em diversas áreas do conhecimento. Os estudos sobre esse tema aportam contribuições de diversos campos, tais como, antropologia, sociologia, e administração.

A grande vantagem da introdução da perspectiva cultural nos estudos de administração é o fato de esta perspectiva reconhecer elementos comos:

1. O fato de que atitudes e valores culturais são diferentes, no mínimo, em grau, se não em termos absolutos de um grupo social para outro;

2. O fato de que os diferentes grupos sociais comportam-se diferentemente em condições similares em função das diferenças nos seus valores e atitudes;

3. O importante papel que a cultura desempenha ao moldar o trabalho nas organizações e outras instituições sociais (TAYEB, 1994).

O papel central da cultura está na influência que ela exerce sobre as orientações particulares que cada indivíduo assume nos jogos estratégicos para defesa de seus interesses e suas convicções no interior de cada grupo social (MOTTA, 1996).

Por essa razão que uma caracterização do ambiente institucional brasileiro é, em última instância, uma caracterização dos elementos que moldam a nossa cultura.

\subsection{Caracterização do ambiente institucional brasileiro}

Freitas (1997), baseado nos autores mencionados anteriormente, estabelece traço brasileiros para uma análise organizacional: a hierarquia, o personalismo, a malandragem, o sensualismo, aventureiro.

A característica de hierarquia é uma herança portuguesa, resultante, por um lado, da influência romana e do processo de instalação do direito canônico na península ibérica. Essa de nobreza episcopal influenciou a introduziu um modelo de relação social dúbia, no qual confundem-se a benção e a dominação. Nos termos de Gilberto Freyre: 
Por outro lado, o modelo da família patriarcal portuguesa instalada durante o processo de colonização fornece-nos o modelo moral que regula as relações entre governantes e governados, definindo as normas de dominação, conferindo a centralização de poder nas mãos dos governantes e subordinação aos governados (FREITAS, 1997).

\begin{tabular}{|c|l|}
\hline Traço & Características-chave \\
\hline Hierarquia & $\begin{array}{l}\text { Tendência a centralização do poder dentro dos grupos sociais } \\
\text { Distanciamento nas relações entre diferentes grupos sociais } \\
\text { Passividade e aceitação dos grupos inferiores }\end{array}$ \\
\hline Personalismo & $\begin{array}{l}\text { Sociedade baseada em relações pessoais } \\
\text { Busca de proximidade e afeto nas relações } \\
\text { Paternalismo: domínio moral e econômico }\end{array}$ \\
\hline Malandragem & $\begin{array}{l}\text { Flexibilidade e adaptabilidade como meio de navegação social } \\
\text { Jeitinho }\end{array}$ \\
\hline Sensualismo & Gosto pelo sensual e exótico nas relações sociais \\
\hline Aventureiro & $\begin{array}{l}\text { Mais sonhador que disciplinado } \\
\text { Tendência à aversão ao trabalho manual ou metódico }\end{array}$ \\
\hline
\end{tabular}

Tabela 3: Sumário dos traços de brasileiros, de Freitas (1997).

A característica do personalismo reflete o caráter relacional da sociedade brasileira (DAMATTA, 1986). Desenvolve-se uma sociedade baseada em relacionamentos próximos e afetuosos, e avessa a qualquer ritualismo ou formalidade. A busca dessa característica relacional manifestase, até mesmo, no sagrado. Precisamos de santos, padroeiros, orixás e espíritos para estar mais próximo do altissímo. Essa característica que parece absurda para protestantes ou católicos franceses, por exemplo (FREITAS, 1997).

Essa característica relacional possui uma contradição latente: como podemos conviver em uma sociedade hierarquizada, e, ao mesmo tempo, buscar proximidade nas relações? Essa diferença é explicada pela influência patriarcal, onde o senhor deixa de ser um detentor do trabalho físico e passa a ser um responsável pela moral. Estabelece-se uma relação de confiança: o patrão protege o empregado como a um filho, e com o empregado sob seu domínio, controla-o. Por sua vez, o empregado, por se sentir protegido, retribui com lealdade a seu superior (DAMATTA, 1986). Estabelecem-se, simultaneamente, uma relação pessoal e econômica.

Tal característica é interessantemente diferente do individualismo puritano e calvinista desenvolvido na Inglaterra durante a Revolução Industrial e espalhado para o mundo. No modelo anglicano, privilegia-se o instituto da homogeneidade e igualdade entre seus membros, onde as relações travam-se diretamente. Nessa lógica, a figura do intermediário é caracterizada por um asco social (FREITAS, 1997).

Na busca de um caminho intermediário entre o "pode" e o "não pode" desenvolve-se o "jeiti- 
nho", um caminho intermediário. É agir com sensibilidade, inteligência, e simpatia para relacionar o impessoal e o pessoal (DAMATTA, 1986). Assim, caracteriza-se a figura do malandro, o mestre na arte do jeitinho. Se por um lado, o malandro é associado com o deliquente, por outro é um arquétipo ideal.

Outra característica assaz importante, levantada por Freitas (1997), é o sensualismo. Ao contrário do que ocorria na Europa do norte, em Portugal a miscigenação sempre foi comum. Ao chegarem no Brasil, depararam-se com índios que tinham uma cultura poligâmica. Por meio do "cunhadismo", os portugueses incorporaram-se ao índios, estabelecendo as primeiras famílias de brasileiros (RIBEIRO, 1995). Nessa linha, desenvolveu-se um sensualismo afetivo (FREITAS, 1997).

O último traço marcante identificado por Freitas (1997) é o espírito aventureiro do povo português. Graças a esse espírito que as navegações foram uma empreita tão bem sucedida. Contudo, esse espírito tem uma aversão ao trabalho manual e metódico. Talvez a melhor expressão dessa característica seja a frase de Macunaíma “Ai que preguiça!".

Baseando-se no mesmo referencial sócio-antropológico, Prates e Barros (1997) desenvolvem um modelo de ação cultural brasileiro com base na gestão empresarial a partir. Tal modelo é organizado em quatro subsistemas: o institucional, o pessoal, o dos líderes e o dos liderados. A oposição institucional versus formal é baseada na distinção de DaMatta (1987) entre a casa e a rua. A interação entre líderes e liderados é claramente influência de Casa-grande \& Senzala.

Esses subsistemas possuem intersecções entre si, nas quais encontram-se traços culturais comuns, como: concentração de poder, personalismo, postura de espectador, e evitar conflito. Os subsistemas são, também, ligados traços culturais especiais, que os responsáveis pela coesão do sistema. São eles: o paternalismo, a lealdade às pessoas, o formalismo e a flexibilidade.

Wood Jr e Caldas (1998) analisam o referencial teórico mencionado e tecem considerações acerca de sua aplicabilidade ao ambiente empresarial brasileiro. Os autores classificam as especificidades brasileiras segundo três perspectivas: institucionais, culturais e organizacionais, conforme apresentado na tabela 4.

\subsubsection{Especificidades institucionais}

As especificidades institucionais referem-se às condições estruturais que norteiam a atividade empresarial (WOOD JR; CALDAS, 1998), destacando-se quatro pontos: baixo grau de institucionalização, baixa intensidade de competição, regulamentação precária e relações conflituosas. 


\begin{tabular}{|c|c|c|}
\hline Institucionais & Culturais & Organizacionais \\
\hline $\begin{array}{l}\text { Baixo grau de institucionali- } \\
\text { zação dos organismos de con- } \\
\text { trole e coordenação }\end{array}$ & $\begin{array}{l}\text { Personalismo: o indivíduo } \\
\text { acima da comunidade }\end{array}$ & $\begin{array}{l}\text { Estratégia: pouco focada em } \\
\text { função de pouca tradição no } \\
\text { tratamento das questões e das } \\
\text { condições ambientais instá- } \\
\text { veis }\end{array}$ \\
\hline $\begin{array}{l}\text { Baixa intensidade de competi- } \\
\text { ção com a presença de mono- } \\
\text { pólios e oligopólios e setores } \\
\text { cartelizados }\end{array}$ & $\begin{array}{l}\text { Ambigüidade: nada é o que } \\
\text { parece ser, e quando é pode } \\
\text { também ser algo mais }\end{array}$ & $\begin{array}{l}\text { Estrutura: presença ainda im- } \\
\text { portante de estruturas hierár- } \\
\text { quicas pesadas e de formas } \\
\text { primitivas de organização do } \\
\text { trabalho }\end{array}$ \\
\hline $\begin{array}{l}\text { Regulamentação precária da } \\
\text { atividade empresarial com ex- } \\
\text { cesso de regulamentação em } \\
\text { alguns casos, e falta de regu- } \\
\text { lamentação em outros }\end{array}$ & $\begin{array}{l}\text { Alta distância do poder: rela- } \\
\text { ções sociais marcadas pela he- } \\
\text { rança escravocata }\end{array}$ & $\begin{array}{l}\text { Estilo gerencial: marcado } \\
\text { pelo autoritarismo, alta dis- } \\
\text { tância do poder e centraliza- } \\
\text { ção das decisões }\end{array}$ \\
\hline $\begin{array}{l}\text { Comunicação imperfeita no } \\
\text { mercado }\end{array}$ & $\begin{array}{l}\text { Plasticidade e permeabili- } \\
\text { dade: abertura e fascinação } \\
\text { com o estrangeiro }\end{array}$ & \\
\hline $\begin{array}{l}\text { Relações conflituosas entre } \\
\text { clientes e fornecedores difi- } \\
\text { cultando alianças e parcerias }\end{array}$ & $\begin{array}{l}\text { Formalismo e "faz-de-conta": } \\
\text { convivência entre o "mundo } \\
\text { de direito" e o"mundo de } \\
\text { fato", mediada pela ambigüi- } \\
\text { dade e pelos comportamentos } \\
\text { de fachada }\end{array}$ & \\
\hline
\end{tabular}

Tabela 4: Modelo de especificidades do ambiente empresarial brasileiro. Adaptado de Wood Jr e Caldas (1998). 
O baixo grau de institucionalização refere-se ao déficit institucional existente no país. Especialmente, ao problema da lentidão do sistema judiciário e dos mecanismos de controle externo. Baixa intensidade de competição refere-se ao fato de a atividade econômica estar concentrada em um monopólio. Poucos grupos de grande porte abrangem diversos setores da economia.

Regulamentação precária refere-se à ausência de marcos regulatórios para alguns setores, ao passo que em excesso em outros. Tome-se por exemplo a regulamentação tributária.

As relações entre fornecedores e clientes tendem a ser naturalmente conflituosas, uma vez que os dois atores possuem objetivos diferentes. No contexto brasileiro, esse fato agrava-se pois existe uma predisposição cultural a perceber o fornecedor com um explorador.

\subsubsection{Especificidades culturais}

O personalismo é uma das mais importantes especificidades brasileiras. No Brasil, a cultura de pessoalidade corresponde ao grande valor atribuído à pessoa em sobreposição ao valor da coletividade. Esse comportamento ocasiona uma falta de coesão na vida social na medida em que cada um favorece os seus e os membros de seu "clã", em detrimento do interesse coletivo (MOTTA; ALCADIPANI, 1999).

Essa faceta do brasileiro é representada pela máxima do ex-presidente Getúlio Vargas: "para os amigos tudo, para os inimigos nada, para os indiferentes a lei”, exemplificando assim que a aplicação da lei é reservada àqueles aos cidadões anônimos (MOTTA, 1997).

A ambigüidade, ou flexibilidade ou adaptabilidade, é a manifestação do "jeitinho brasileiro". Isto é, uma estratégia para suavização das formas impessoais que regem as relações pessoais (MOTTA, 1997). A ambigüidade manifesta-se, principalmente, nas relações que deveriam ser intermediadas pela dominação burocrática weberiana (MOTTA; ALCADIPANI, 1999).

A alta distância do poder possui um caráter hierarquizante, mas ao mesmo tempo paternal e personalista.

A plasticidade e permeabilidade são características associadas com a própria formação histórica e econômica do Brasil, tendo como raízes a tendência à dependência, e o gosto pelo estrangeiro, pelo exótico (MOTTA, 1997).

A postura paternalista adotada durante o processo colonizador desenvolveu um traço que nutre uma postura de expectador, isto é, uma dependência de alguém que conduza o indivíduo.

A permeabilidade está associada com uma preferência pelo estrangeiro (pessoa ou produto). 
Tome-se por exemplo, o natal brasileiro que tem como temática o inverno dos países europeus, isso em pleno verão tropical. Associada com essa preferência, tem-se um gosto pelo diferente, derivado de uma falta de orgulho de sua própria raça típica do português.

O formalismo é a diferença entre a conduta concreta e a norma que estabelece como essa conduta deveria ser, sem que tal diferença implique em punição para o infrator (MOTTA; ALCADIPANI, 1999; RIGGS, 1964). Para Riggs (1964), o formalismo é resultante da imposição de estruturas sociais de países desenvolvidos à sociedades em desenvolvimento. Exige-se uma determinada postura social sem, contudo, aquele conceito ter sido internalizado.

A postura formalista estava presente desde os primórdios da formação brasileira. Prado Jr (1948) observa que essa prática já estava presente nos tempos do Brasil Colônia.

\subsubsection{Especificidades organizacionais}

A estratégia pouco focada é uma característica resultante da ausência de uma visão de longoprazo. Em parte derivada da herança colonial que via o Brasil apenas como um fornecedor de recursos, e não como um nova pátria.

O estilo gerencial marcado pelo distanciamento nas relações de poder é associado com o passado colonial. Na colônia, estabeleceu-se relações de poder com claras distinções entre líderes e liderados.

Estrutura rígida é um resultado das distinções entre líderes e liderados. 


\section{METODOLOGIA DA PESQUISA}

\subsection{Problemática de pesquisa}

\subsubsection{Questão de pesquisa}

A questão da importação de tecnologia gerencial na literatura brasileira de administração tem larga influência dos trabalhos de Wood Jr e Caldas (1998). Para esses autores, a melhor metáfora para se compreender o processo de importação é antropofagia organizacional.

O conceito de antropofagia, no seu sentido literal, refere-se a um ritual de guerra de algumas tribos indígenas no qual alimentavam-se dos vencidos. Ao fazê-lo, acreditavam estar sugando a sua coragem e energia, num ato de respeito e honra (WOOD JR; CALDAS, 1998).

Metaforicamente, esse conceito foi retomado no início do século XX pela vanguarda intelectual e artística que denunciava uma apropriação exagerada e sem sentido da cultura estrangeira. Por outro lado, esses mesmos intelectuais comprometeram-se com a modernidade e o cosmopolitanismo, propondo assim um antropofagismo literário, isto é, uma apropriação despudorada de idéias e conceitos estrangeiros, porém com seus significados alterados pelos valores locais (ANDRADE, 1928).

Similar ao que ocorreu nas primeiras décadas do século XX com a importação de valores culturais, vive-se no Brasil contemporâneo um movimento de importação de tecnologia gerencial. Esse movimento bastante forte na década de 1990, renova-se e apresenta uma nova linguagem para o mercado de serviços de TI. Nunca antes vivenciou-se um movimento pela adoção de metodologias de gestão e de qualidade.

Pode citar-se os modelos ITIL e COBIT como referência na gestão dos serviços de TI, ou o modelo CMMi para desenvolvimento de software. Fernandes e Abreu (2008) identificam mais de vinte modelos para o gerenciamento de serviços.

Diante dessa ampla gama de modelos disponíveis, emerge o questionamento acerca de qual deles realmente é adequado ou aplicável ao contexto e as especificidades das organizações e do mercado de tecnologia brasileiro.

Com o amadurecimento das práticas de fornecimento de serviços de TI, modelos de governança começam a surgir. Dentre estes, o modelo eSourcing Capabilty Model é um modelo voltado totalmente para as práticas de sourcing de TI, abrangendo as perspectivas do fornecedor e do cliente. 
O estudo da adequação dos modelos de governança de TI ao contexto brasileiro ainda são incipientes. Considerando essa oportunidade de contribuição, propõe-se uma investigação acerca da adequação das premissas do modelo eSCM ao contexto institucional brasileiro. Assim, a questão de pesquisa é:

\section{Qual as implicações das premissas do modelo eSCM para sua aplicabilidade ao contexto institucional brasileiro?}

Essa questão se desdobra em:

1. Quais as premissas do eSCM?

2. Como essas premissas articulam-se no contexto institucional brasileiro?

\subsubsection{Objetivos de pesquisa}

Tendo em vista as motivações e as questões de investigação apresentas, o objetivo geral da pesquisa é:

Avaliar a adequação das premissas do modelo eSCM visando compreender sua efetividade, quando da aplicação na padronização dos processos de contratação e gestão de terceirização de serviços de tecnologia da informação, no contexto institucional e econômico brasileiro.

Para o alcance desse objetivo geral, a pesquisa possui os seguintes objetivos específicos:

1. Identificar padrões de contextos organizacionais encontrados na contratação e gestão de terceirização de serviços de tecnologia da informação;

2. Identificar lacunas da aplicação do eSCM, isto é, situações nas quais os modelos não se aplicam de forma efetiva ao contexto organizacional.

\subsection{Estratégia metodológica}

O problema de pesquisa dessa dissertação consiste em um indagação acerca das implicações das premissas do modelo eSCM para a aplicabilidade desse modelo ao contexto institucional brasileiro. Para responder essa questão, depara-se com dificuldades metodológicas, tais como:

1. Como identificar as premissas do modelo eSCM?

2. Como comparar as premissas do modelo eSCM com o ambiente institucional brasileiro? 


\section{Como validar essa comparação?}

Uma das possibilidades metodológicas encontradas na literatura é o método antropofágico de Wood Jr e Caldas (1998), no qual é proposto analisar os modelos em cinco etapas:

1. Identificar pressupostos - visa identificar é identificar e isolar as premissas, raramente declaradas e explícitas, na qual o modelo está assentado;

2. Testar validade e filtrar pressupostos - analisar os pressupostos isoladamente afim de identificar a existência de consistência com as especificidades do contexto local;

3. Inserir especificidades locais - adicionar aspectos e premissas peculiares do contexto local que não existiam no modelo original, em substituição e em adição àqueles filtrados por inadequação;

4. Reconstruir modelo - o modelo é reconstruído conceitual ou logicamente, incorporando os novos e antigos requisitos de forma de forma coerente;

5. Testar e implantar modelo - teste e implantação do modelo.

Afim de responder essas indagações, é necessário considerar a natureza dos elementos que estão sendo estudados: um modelo e suas premissas.

O modelo eSCM, na forma como é apresentado, é, essencialmente, um objeto textual. Portanto, as técnicas a serem aplicadas devem, também, ser técnicas de análise textual ou análise literária.

Dentre as técnicas existentes, optou-se pela análise de conteúdo como a mais adequada para responder ao questionamento.

Uma vez encontradas as premissas do modelo, ainda resta-nos o problema de comparação e validação.

A comparação foi realizada por meio do uso de análise institucional comparativa.

A validação foi feita por meio de entrevista com especialistas.

Esse método é alinhado com a pergunta de pesquisa, contudo não é objetivo desta pesquisa reconstruir o modelo eSCM. Assim, serão realizadas as duas primeiras etapas.

\subsubsection{Análise de conteúdo}

A análise de conteúdo não é estritamente um instrumento, mas, antes, um "conjunto de técnicas de análise das comunicações" (BARDIN, 2008, p. 33) que ocorre em três etapas: 
1. pré-análise

2. exploração do material

3. tratamento dos resultados, inferência e interpretação

Na exploração do material ocorre a codificação e a categorização

Para inferência Bardin (2008) elenca seis técnicas:

1. Análise categorial

2. Análise de avaliação

3. Análise da enunciação

4. Análise proposicional do discurso

5. Análise da expressão

6. Análise das relações

\subsubsection{Análise comparativa}

O método da análise comparativa é proveniente do campo da Economia Institucional. Essencialmente consiste na comparação de dois ou mais arranjos institucionais e verificação dos resultados dessas escolhas.

A análise comparativa fornece subsídios para uma análise positiva quanto normativa das mudanças institucionais. Como análise positiva, ela tenta predizer os resultados dos vários arranjos institucionais com base nos incentivos dos agentes em cada contexto. Como análise normativa, tenta determinar a melhor escolha institucional, isto é, a escolha que maximiza o ganho coletivo dos agentes (FREIWALD, 2001).

Por exemplo, a mecanismo de escolha de padrões adotado pela Organização Mundial do Comércio (OMC) e pela União Européia (EU) é o tema do estudo de Costinot (2008). Ao passo que a OMC baseia suas escolhas no princípio dos tratados nacionais, a EU baseia-se no princípio do reconhecimento mútuo. Realizando uma análise por meio de jogos, o autor verifica que o mecanismo da OMC possui níveis de externalidades menores do que a EU, devendo aquele ser preferido nas transações caracterizadas por altos níveis de externalidades. 


\subsubsection{Validação das análises}

As premissas identificadas na análise de conteúdo e comparadas serão validades com informantes. Os informantes são especialistas no tema. Nas entrevistas, para cada uma das premissas, pretende-se questionar os informantes acerca de elementos como (SPRADLEY, 1979):

- O que meus informantes sabem sobre sua cultura que eu possa descobrir?

- Quais conceitos meus informantes usam para classificar suas experiências?

- Como meus informantes definem esses conceitos?

- Qual teoria popular meus informantes usam para explicar sua experiência? 


\section{ANÁLISE}

\subsection{Contextualização do modelo eSCM}

O eSourcing Capability Model (eSCM) é um modelo de referência para as atividades de prestação de serviços de TI (sourcing) projetado com o intuito de complementar os demais modelos de qualidade existentes no mercado, como o COBIT, ITIL, CMMi, dentre outros ${ }^{1}$.

O seu desenvolvimento deu-se no Information Technology Services Qualification Center (ITSqc) da Universidade Carnegie Mellon, nos Estados Unidos, no âmbito do ITSqc research consortium. Esse consórcio é composto por representantes de fornecedores e clientes de TI, além do meio acadêmico. Destaque-se a forte presença brasileira representada pela Universidade Federal do Rio de Janeiro, o Capítulo brasileiro do itSMF e a DBA engenharia de sistemas.

Quando da formulação desses modelos, o ITSqc tinha como propósito para essa empreita:

1. Ajudar provedores e clientes de serviços suportados por TI a avaliar e melhorar sua capacidade de oferecer e comprar serviços de alta qualidade;

2. Prover as organizações certificadas com um padrão de qualidade de reconhecida excelência em termos mundiais, considerado um fator diferencial;

3. Permitir a organizações que adquirem tais serviços, um instrumento de comparação de organizações provedoras de serviços apoiados por TI.

O ITSqc e o eSCM foram desenvolvidos dentro do contexto da Universidade de Carnegie Mellon, uma universidade com tradição na área de tecnológica. Nesta mesma universidade situa-se o Software Engineering Institute (SEI), um dos centros de referências internacionais na área de desenvolvimento de software. Um dos projetos iminentes do SEI são os modelos CMM (Capability Maturity Model) e o CMMi (Capability Maturity Model Integration), ambos são modelos de referência para qualidade no desenvolvimento de software.

\subsubsection{Membresia do ITSqc Research Consortium}

Um aspecto importante do ITSqc é sua estrutura de membresia. Ainda que seja um centro de pesquisa ligado a uma universidade, possui membros da comunidade externa que se dividem entre os tipos: fundador, associado, contribuinte ou afiliado.

\footnotetext{
${ }^{1}$ Essas informações foram retiradas do site do ITSqc (http://itsqc.cmu.edu/) e do Grupo de Produção Integrada da Universidade Federal do Rio de Janeiro (http://www.gpi.ufrj.br/index.html).
} 
Os membros fundadores do consórcio são organizações selecionadas que representam pontos estratégicos na economia em desenvolvimento. Possuem um papel estratégico. Estes membros contribuem com US\$ 500.000,00 por ano, durante cinco anos e têm uso ilimitado de todos os materiais desenvolvidos pelo ITsqc.

Os membros associados e os contribuintes do consórcio são organizações selecionadas que compartilham a visão do ITsqc, tornando-se envolvidas seriamente nas missões de pesquisa e desenvolvimento do Instituto. Como fundadores, os associados e contribuintes também possuem assentos no Advisory Board do eSCM.

Os membros associados suportam a pesquisa e o desenvolvimento relacionado a um único modelo e ao seu método de determinação de "capability", provendo uma contribuição de US\$ 200.000,00 por ano, durante três anos, possuindo uso ilimitado do ganho do retorno desse único modelo.

Os membros contribuintes, por sua vez, suportam a pesquisa e o desenvolvimento relacionado a um único modelo e o seu método de determinação, provendo uma contribuição de US\$ $100.000,00$ por o ano, durante três anos, além de garantir uso ilimitado do ganho do retorno desse único modelo para o uso interno.

Os membros afiliados do ITsqc compõem um grupo mais amplo de organizações interessadas no trabalho do ITsqc, mas não interessadas no envolvimento direto com o Centro, sendo aquelas organizações que desejam participar no desenvolvimento de um modelo e dos métodos associados de determinação.

Cada afiliado contribui com uma quantia que varia entre US\$10.000 a US\$ 50.000 anualmente, oferecida ao fundo de pesquisa do ITsqc, dependendo de suas características organizacionais. A contribuição anual é um fomento irrestrito, com nenhum direito de propriedade intelectual associado. A renovação da sociedade no programa é automática e baseada no pagamento de taxas anuais.

O ITsqc também incentiva o envio de pesquisadores qualificados para trabalhar na universidade de Carnegie Mellon como

As organizações podem enviar membros para períodos de residência no ITsqc. As organizações que enviam Visiting ou Industrial Scholars pagam uma taxa anual de US\$ 65.000 por ano para cobrir a pesquisa básica e as despesas administrativas do scholar na universidade de Carnegie Mellon.

Além destas modalidades, tem-se os pilot sites e os revisores de modelo. 
As organizações que não contribuem diretamente ao modelo, aos métodos e aos esforços do repositório, podem aplicar-se com um local piloto. Desta forma, a participação do pessoal da organização no método de avaliação e, em retorno, há a possibilidade de acesso pioneiro ao modelo e ao método de determinação da "capability".

Os indivíduos que desejam participar na revisão pública dos modelos de melhores práticas que estão sendo desenvolvidos no ITsqc podem fazer parte dos grupos de revisores. Cada grupo é dedicado a um modelo específico. A participação em um grupo de revisão é também uma maneira do revisor ser mantido informado sobre o desenvolvimento do modelo em questão.

\subsection{Descrição do modelo eSCM}

O modelo eSCM foi estruturado em práticas. As práticas são "melhores práticas" que podem ser associadas com uma iniciativa de fornecimento de serviços de sucesso (HEFLEY; LOESCHE, 2006; HYDER; HESTON; PAULK, 2006). Cada prática é refletida em três dimensões: ciclo de vida do fornecimento de serviços, área de capacidade, nível de capacidade.

\subsubsection{Práticas e áreas de capacidade}

As práticas são as próprias recomendações do modelo, ou como descrito no modelo eSCM são as "melhores práticas" a serem adotadas para uma iniciativa de fornecimento de serviços de sucesso (HEFLEY; LOESCHE, 2006; HYDER; HESTON; PAULK, 2006). Cada prática contém um breve resumo, uma descrição e a lista de atividades a serem executadas, além de informações complementares, quando se fazem necessárias.

As áreas de capacidades são os agrupamentos lógicos das práticas cuja função é ajudar os usuários a se lembrarem das práticas assim como gerenciar o conteúdo do modelo (HEFLEY; LOESCHE, 2006; HYDER; HESTON; PAULK, 2006).

No modelo eSCM-SP, a versão para fornecedores, são descritas 84 práticas agrupadas em nove áreas de capacidades, como mostrado na tabela 5.

Tabela 5: Práticas do modelo eSCM-SP

\begin{tabular}{|c|l|}
\hline Código & Prática / Área de prática \\
\hline KNW & KNOWLEDGE MANAGEMENT \\
knw01 & Share knowledge \\
knw02 & Provide required information \\
\hline
\end{tabular}


Tabela 5: Práticas do modelo eSCM-SP (continuação)

\begin{tabular}{|c|c|}
\hline Código & Prática / Área de capacidade \\
\hline knw03 & Knowledge system \\
\hline knw04 & Process assets \\
\hline knw05 & Engagement knowledge \\
\hline knw06 & Reuse \\
\hline knw07 & Version \& change control \\
\hline knw08 & Resource consumption \\
\hline PPL & PEOPLE MANAGEMENT \\
\hline ppl01 & Encourage innovation \\
\hline ppl02 & Participation in decisions \\
\hline ppl03 & Work environment \\
\hline ppl04 & Assign responsibilities \\
\hline ppl05 & Define roles \\
\hline ppl06 & Workforce competencies \\
\hline ppl07 & Plan \& delivery trainings \\
\hline ppl08 & Personnel competencies \\
\hline ppl09 & Performance feedback \\
\hline ppl010 & Career development \\
\hline ppl011 & Rewards \\
\hline PRF & PERFORMANCE MANAGEMENT \\
\hline prf01 & Engagement objectives \\
\hline prf02 & Verify processes \\
\hline prf03 & Adequate resources \\
\hline prf04 & Organizational objectives \\
\hline prf05 & Review organizational performance \\
\hline prf06 & Make improvements \\
\hline prf07 & Achieve organizational objectives \\
\hline prf08 & Capability baselines \\
\hline prf09 & Benchmark \\
\hline prf010 & Prevent potential problems \\
\hline prf011 & Deploy innovations \\
\hline
\end{tabular}


Tabela 5: Práticas do modelo eSCM-SP (continuação)

\begin{tabular}{|c|c|}
\hline Código & Prática / Área de capacidade \\
\hline REL & RELATIONSHIP MANAGEMENT \\
\hline rel01 & Client interactions \\
\hline rel02 & Select suppliers \& partners \\
\hline rel03 & Manage suppliers \& partners \\
\hline rel04 & Cultural fit \\
\hline rel05 & Stakeholder information \\
\hline rel06 & Client relationships \\
\hline rel07 & Supplier \& partner relationships \\
\hline rel08 & Value creation \\
\hline $\mathrm{TCH}$ & TECHNOLOGY MANAGEMENT \\
\hline $\operatorname{tch} 01$ & Acquire technology \\
\hline $\operatorname{tch} 02$ & Technology licenses \\
\hline $\operatorname{tch} 03$ & Control technology \\
\hline $\operatorname{tch} 04$ & Technology integration \\
\hline $\operatorname{tch} 05$ & Optimize technology \\
\hline $\operatorname{tch} 06$ & Proactively introduce technology \\
\hline THR & THREAT MANAGEMENT \\
\hline thr01 & Risk management \\
\hline thr02 & Engagement risk \\
\hline thr03 & Risk across engagements \\
\hline thr04 & Security \\
\hline thr05 & Intellectual property \\
\hline thr06 & Statutory \& regulatory compliance \\
\hline thr07 & Disaster recovery \\
\hline CNT & CONTRACTING \\
\hline $\operatorname{cnt} 01$ & Negotiations \\
\hline $\operatorname{cnt} 02$ & Pricing \\
\hline $\operatorname{cnt} 03$ & Confirm existing conditions \\
\hline $\operatorname{cnt} 04$ & Market information \\
\hline $\operatorname{cnt} 05$ & Plan negotiations \\
\hline
\end{tabular}


Tabela 5: Práticas do modelo eSCM-SP (continuação)

\begin{tabular}{|c|c|}
\hline Código & Prática / Área de capacidade \\
\hline cnt06 & Gather requirements \\
\hline cnt07 & Review requirements \\
\hline cnt08 & Respond to requirements \\
\hline cnt09 & Contract roles \\
\hline cnt010 & Create contracts \\
\hline cnt011 & Amend contracts \\
\hline SDD & SERVICE DESIGN \& DEPLOYMENT \\
\hline sdd01 & Communicate requirements \\
\hline sdd02 & Design \& deploy service \\
\hline sdd03 & Plan design \& deployment \\
\hline sdd04 & Service specification \\
\hline sdd05 & Service design \\
\hline sdd06 & Design feedback \\
\hline sdd07 & Verify design \\
\hline sdd08 & Depoly service \\
\hline DEL & SERVICE DELIVERY \\
\hline del01 & Plan service delivery \\
\hline del02 & Train clients \\
\hline del03 & Delivery service \\
\hline del04 & Verify service commitments \\
\hline del05 & Correct problems \\
\hline del06 & Prevent known problems \\
\hline del07 & Service modifications \\
\hline del08 & Financial management \\
\hline TRF & SERVICE TRANSFER \\
\hline $\mathrm{tfr} 01$ & Resources transferred in \\
\hline $\mathrm{tfr} 02$ & Personnel transferred in \\
\hline tfr03 & Service continuity \\
\hline tfr04 & Resources transferred out \\
\hline $\mathrm{tfr} 05$ & Personnel transferred out \\
\hline
\end{tabular}


Tabela 5: Práticas do modelo eSCM-SP (continuação)

\begin{tabular}{|c|l|}
\hline Código & Prática / Área de capacidade \\
\hline tfr06 & Knowledge transferred out \\
\hline
\end{tabular}

No modelo eSCM-CL, a versão para clientes, são descritas 95 práticas agrupadas em 17 áreas de capacidades, como mostrado na tabela 6.

Tabela 6: Práticas do modelo eSCM-CL

\begin{tabular}{|c|l|}
\hline Código & Prática / Área de prática \\
\hline STR & SOURCING STRATEGY MANAGEMENT \\
str01 & Sourcing sponsorship \\
str03 & Sourcing constrains \\
str04 & Potential sourcing areas \\
str05 & Organizational sourcing strategy \\
GOV & GOVERNANCE MANAGEMENT \\
gov01 & Sourcing policy \\
gov02 & Service provider management \\
gov03 & Internal stakeholder management \\
gov04 & Defined sourcing processes \\
gov05 & Align strategy \& architectures \\
gov06 & Business process integration \\
gov07 & Adapt to business change \\
rel03 & Internal relationships \\
rel04 & Issue management \\
rel01 & RELATIONSHIP MANAGEMENT \\
\hline
\end{tabular}


Tabela 6: Práticas do modelo eSCM-CL (continuação)

\begin{tabular}{|c|c|}
\hline Código & Prática / Área de capacidade \\
\hline VAL & VALUE MANAGEMENT \\
\hline val01 & Organizational sourcing performance \\
\hline val02 & Capability baselines \\
\hline val03 & Benchmark sourcing processes \\
\hline val04 & Improve sourcign processes \\
\hline val05 & Innovation \\
\hline val06 & Business value $\&$ impact \\
\hline val07 & Sourcign alignment \\
\hline OCM & ORGANIZATIONAL CHANGE MANAGEMENT \\
\hline ocm01 & Prepare for organizational change \\
\hline ocm02 & Stakeholder involvement \\
\hline ocm03 & Define future state \\
\hline ocm04 & Human resources changes \\
\hline ocm05 & Communicate organizational changes \\
\hline ocm06 & Organizational change \\
\hline PPL & PEOPLE MANAGEMENT \\
\hline ppl01 & Assign sourcing responsiblities \\
\hline ppl02 & Personnel competencies \\
\hline ppl03 & Organizational sourcing competencies \\
\hline ppl04 & Define roles \\
\hline KNW & KNOWLEDGE MANAGEMENT \\
\hline knw01 & Provide required information \\
\hline knw02 & Knowledge system \\
\hline knw03 & Market information \\
\hline knw04 & Lessons learned \\
\hline knw05 & Share knowledge \\
\hline $\mathrm{TCH}$ & TECHNOLOGY MANAGEMENT \\
\hline $\operatorname{tch} 01$ & Asset management \\
\hline $\operatorname{tch} 02$ & License management \\
\hline
\end{tabular}


Tabela 6: Práticas do modelo eSCM-CL (continuação)

\begin{tabular}{|c|c|}
\hline Código & Prática / Área de capacidade \\
\hline $\operatorname{tch} 03$ & Technology integration \\
\hline THR & THREAT MANAGEMENT \\
\hline thr01 & Sourcing risk management \\
\hline thr02 & Organizational risk management \\
\hline thr03 & Intellectual property \\
\hline thr04 & Security \& privacy \\
\hline thr05 & Compliance \\
\hline thr06 & Business continuity \\
\hline OPA & SOURCING OPPORTUNITY ANALYSIS \\
\hline opa01 & Define current state \\
\hline opa02 & Sourcing criteria \\
\hline opa03 & Demand identification \\
\hline opa04 & Sourcing options \\
\hline APP & SOURCING APPROACH \\
\hline app01 & Sourcing approach \\
\hline app02 & Business case \\
\hline app03 & Governance model \\
\hline app04 & Impact $\&$ risk analysis \\
\hline app05 & Sourcing initiation decision \\
\hline PLN & SOURCING PLANNING \\
\hline pln01 & Establish sourcing project \\
\hline pln02 & Service definition \\
\hline pln03 & Service provider selection procedures \\
\hline pln04 & Evaluation criteria \\
\hline pln05 & Prepare service requirements \\
\hline SPE & SERVICE PROVIDER EVALUATION \\
\hline spe01 & Communicate requirements \\
\hline spe02 & Evaluate potential service providers \\
\hline
\end{tabular}


Tabela 6: Práticas do modelo eSCM-CL (continuação)

\begin{tabular}{|c|c|}
\hline Código & Prática / Área de capacidade \\
\hline spe03 & Select candidate service providers \\
\hline AGR & SOURCING AGREEMENTS \\
\hline agr01 & Negotiation guidelines \\
\hline agr02 & Confirm existing conditions \\
\hline agr03 & Negotiations \\
\hline agr04 & Agreements roles \\
\hline agr05 & Define SLAs \& measures \\
\hline agr06 & Create agreements \\
\hline agr07 & Amend agreements \\
\hline TRF & SERVICE TRANSFER \\
\hline $\operatorname{trf01}$ & Service transition \\
\hline $\operatorname{trf02}$ & Verify design \\
\hline $\operatorname{trf03}$ & Resources transferred out \\
\hline trf04 & Personnel transferred out \\
\hline $\operatorname{trf05}$ & Knowledge transferred out \\
\hline MGT & SOURCED SERVICE MANAGEMENT \\
\hline mgt01 & Perform sourcign management \\
\hline mgt02 & Perform monitoring \\
\hline mgt03 & Financial management \\
\hline mgt04 & Agreement management \\
\hline mgt05 & Problem \& incident monitoring \\
\hline mgt06 & Service delivery change management \\
\hline mgt07 & Service change management \\
\hline $\operatorname{mgt} 08$ & Review service performance \\
\hline mgt09 & Stakeholder feedback \\
\hline $\operatorname{mgt} 010$ & Service value analysis \\
\hline $\operatorname{mgt} 011$ & Continuation decision \\
\hline CMP & SOURCING COMPLETION \\
\hline cmp01 & Completion planning \\
\hline
\end{tabular}


Tabela 6: Práticas do modelo eSCM-CL (continuação)

\begin{tabular}{|l|l|}
\hline Código & Prática / Área de capacidade \\
\hline cmp02 & Service continuity \\
cmp03 & Resources transferred from service provider \\
cmp04 & Personnel transferred from service provider \\
cmp05 & Knowledge transferred from service provider \\
\hline
\end{tabular}

\subsubsection{Ciclo de vida}

Um dos aspectos considerados na estrutura do modelo eSCM são os momentos de ciclo de vida. O modelo enfoca atividades que são dependentes do momento (temporal) da atividade de fornecimento de serviços. São cinco os momentos do ciclo de vida do modelo eSCM: Em andamento (ongoing), análise, iniciação, entrega, encerramento.

\subsubsection{Em andamento}

As práticas em andamento representam as funções gerenciais que precisam ser executadas durante todo o ciclo de vida da iniciativa de fornecimento do serviço. Algumas práticas do momento em execução tipicamente ocorrem durante um nível particular de prestação do serviço, ocorrendo nas diversas fases do ciclo de vida. Outras práticas ocorrem esporadicamente ou quando necessário (HEFLEY; LOESCHE, 2006).

\subsubsection{Análise}

As práticas de análise enfocam as capacidades necessárias para identificar dentro da organização quais os processos, funções, ou serviços que podem ser fornecidos por um fornecedor externo, além de identificar quais as abordagens a serem empregadas para cada oportunidade (HEFLEY; LOESCHE, 2006).

\subsubsection{Iniciação}

As práticas de iniciação enfocam nas capacidades necessárias para iniciar o gerenciamento da iniciativa de fornecimento de serviços. Em geral, essas práticas são relacionadas com a definição das funções de gerenciamento, seleção e avaliação de fornecedores, negociação, estabelecimento de acordos, e transferência de recursos (HEFLEY; LOESCHE, 2006). 


\subsubsection{Entrega}

As práticas de entrega de serviços enfocam as capacidades necessárias para o monitoramento do fornecedor de serviços, incluindo o monitoramento de desempenho do fornecedor de serviços, monitoramento de mudanças e outros aspectos (HEFLEY; LOESCHE, 2006).

\subsubsection{Encerramento}

As práticas de encerramento enfocam as capacidades necessárias para o encerramento efetivo do relacionamento de prestação de um determinado serviço, inclui a transferência de recursos para o cliente (HEFLEY; LOESCHE, 2006).

\subsubsection{Níveis de capacidade}

A terceira dimensão do eSCM são os níveis de capacidade. Os cinco níveis do modelo descrevem o caminho de desenvolvimento que é esperado da organização. O nível mais básico é a prestação do serviço. O segundo nível é a gestão consistente dos serviços fornecidos. O terceiro nível enfoca a gestão do desempenho organização do serviço. O quarto nível enfoca a geração de valor. O quinto e último nível refere-se à sustentação da excelência.

\subsection{Relação do eSCM com outros modelos}

Atualmente o ITSqc research consortium vem procurando estabelecer pontos de ligação do eSCM com outros modelos, buscando estabelecer complementariedade.

Kaul e Paulk (2006) analisam as relações conceituais entre o eSCM e Six Sigma e identificam cinco pontos de convergência entre as duas metodologia, pois ambas:

1. Buscam agregar valor à organização por meio da definição e controle da implementação dos objetivos estratégicos;

2. Enfocam a qualidade como elemento crítico para o sucesso da iniciativa de sourcing;

3. Quantificam os custos associados com a baixa qualidade dos processos;

4. O modelo DMAIC ${ }^{2}$ pode ser usado na implantação de todas as práticas, mas os processos

\footnotetext{
${ }^{2}$ DMAIC é um acrônimo para Definir (Define), Mensurar (Measure), Analisar (Analyze), Melhorar (Improve), e Controlar (Controlar)
} 
DFSS $^{3}$ podem ser usados para realizar benchmark.

5. Possuem os mesmos direcionamento e objetivos primários.

Similaridades entre o eSCM-SP e a norma ISO 9001:2000 são encontrados por Guha et al. (2005), como apresentado na tabela 7.

\begin{tabular}{|c|c|c|}
\hline & eSCM-SP v2 & ISO 9001:2000 \\
\hline Público alvo & $\begin{array}{l}\text { Fornecedores de serviços de } \\
\text { TI }\end{array}$ & $\begin{array}{l}\text { Fornecedores de todos os tipos de } \\
\text { produtos, incluindo serviços }\end{array}$ \\
\hline Objetivo & $\begin{array}{l}\text { Criar e melhoraras as capa- } \\
\text { cidades do fornecedor para } \\
\text { atender as demandas durante o } \\
\text { ciclo de vida do sourcing }\end{array}$ & $\begin{array}{l}\text { Fornece os requisitos para implantar } \\
\text { efetivamente um sistema de controle } \\
\text { de qualidade de forma a atender as ne- } \\
\text { cessidades dos clientes e marcos regu- } \\
\text { latórios }\end{array}$ \\
\hline Tamanho & $\begin{array}{l}84 \text { práticas em } 10 \text { áreas de ca- } \\
\text { pacidade }\end{array}$ & 51 cláusulas \\
\hline Abrangência & $\begin{array}{l}10 \text { áreas de capacidade } \\
\text { Ciclo de vida do sourcing em } \\
4 \text { etapas } \\
\text { ongoing } \\
\text { iniciação } \\
\text { Entrega } \\
\text { Encerramento } \\
5 \text { níveis de maturidade }\end{array}$ & $\begin{array}{l}5 \text { cláusulas em sistemas de gestão da } \\
\text { qualidade } \\
11 \text { cláusulas em gestão de responsabi- } \\
\text { lidade } \\
5 \text { cláusulas em gestão de recursos } \\
20 \text { cláusulas em realização do produto } \\
10 \text { cláusulas de mensuração, análise e } \\
\text { melhoria }\end{array}$ \\
\hline Reconhecimento & $\begin{array}{l}\text { A certificação é feita pela Uni- } \\
\text { versidade Carnegie Mellon e é } \\
\text { válida por dois anos. }\end{array}$ & $\begin{array}{l}\text { A certificação é realizada por órgãos } \\
\text { credenciados nos sistemas nacionais } \\
\text { de qualidade. Reavaliação contínua é } \\
\text { necessária para a manutenção da cer- } \\
\text { tificação. }\end{array}$ \\
\hline
\end{tabular}

Tabela 7: Comparação dentre o eSCM-SP v2 e a norma ISO 9001:20001. Adaptado de Guha et al. (2005).

\subsection{Práticas selecionadas}

A revisão de literatura procurou evidenciar que a governança de sourcing possui fortes componentes sociais e humanos. Por isso na seleção das práticas do eSCM para formar o corpus da análise, buscou-se aquelas nas quais esses componentes pudessem manifestar-se.

Desse modo foram escolhidas três áreas de capacidades do eSCM-SP:

\footnotetext{
${ }^{3}$ Acrônimo para Define for Six Sigma.
} 
1. Sourcing strategy management (STR);

2. Sourcing governance (GOV);

3. Relationship Management (REL).

A área de capacidade STR é voltada para a gestão do processo de formulação da estratégia organizacional de sourcing. GOV descreve os processos necessários para se implantar a governança e REL apresenta as recomendações para gerenciamento da relação com os clientes internos e externos.

O detalhamento das práticas que compõem cada área de capacidade é apresentado a seguir.

\subsubsection{Sourcing Strategy Management}

As práticas de Gestão da estratégia de fornecimento de serviços (Sourcing Strategy Management - STR) são apresentadas dentro do modelo eSCM-CL. Seu foco é a definição da estratégia e dos objetivos de fornecimento dos serviços. Todas as práticas do grupo STR ocorrem no momento 'em andamento' (ongoing) do ciclo de vida. Essa área de capacidade busca fornecer melhores práticas para o processo de definição de uma estratégia organizacional das atividades que podem ser fornecidas por fornecedores externos, assim como ser um cliente informado de serviços baseados em TI (HEFLEY; LOESCHE, 2006).

Os aspectos centrais cobertos por esse conjunto de prática abrangem a determinação de uma estratégia organizacional de fornecimento de serviços, e não uma estratégia para um serviço particular. Trata-se de um processo iterativo baseado em entradas do histórico da organização de relacionamento com fornecedores. Esse conjunto de práticas visa auxiliar a organização em questões como: a organização deve engajar no uso de fornecedores externos? se sim, qual estratégia adotar em termos de parceria simples, alianças, ou outras formas de arranjos (HEFLEY; LOESCHE, 2006).

A área de capacidade STR é composta por cinco práticas:

1. Sourcing Strategy;

2. Sourcing Constranits;

3. Potential Sourcing Areas;

4. Sourcing objectives;

5. Organizational Sourcing Activities. 


\subsubsection{STR01 - Sourcing sponsorship}

A garantia do correto nível de patrocínio e comprometimento das iniciativas de sourcing pela alta gestão é um fator crítico para nas organizações que adotam essas práticas, sobretudo pelo fato de que o fornecimento de serviços ser uma iniciativa que atravessa diversos grupos funcionais dentro da organização. A alta gestão deve possuir uma visão de todos os objetivos organizacionais associados, compreender as mudanças associadas com a prática de sourcing, além de garantir os objetivos de longo-prazo associado com o sourcing. Desse modo, a alta gestão demonstra para os funcionários e gerentes o seu comprometimento com a iniciativa de sourcing. Nessa mesma linha, quando a alta gestão compreende os potenciais benefícios futuros do sourcing, torna-se possível tomar decisões de negócio alinhadas com as decisões de sourcing. No oposto, uma alta gestão desinformada ou não alinhada com o sourcing pode tomar decisões que venham a romper o alinhamento organizacional entre as práticas de negócio e de sourcing.

Por essa razão, o patrocínio deve ser garantido no nível correto para se garantir o escopo e as perspectivas estratégicas para as atividades de sourcing. O gerenciamento estratégico, dentro do modelo eSCM-CL, é no nível dos indivíduos cuja função primária é garantir a vitalidade de longo-prazo da organização, ao invés de preocupações com serviços de curto prazo.

A gestão estratégica, no contexto do eSCM-CL, deve garantir que objetivos, recursos, processos e procedimentos estejam alinhados com as atividades organizacionais de sourcing, assim como os objetivos e estratégias de sourcing estejam alinhadas e integradas com os objetivos e estratégias organizacionais. Para grandes organizações, a alta gestão é composta tipicamente pelos executivos ou 'C-level' (Chief Executive Officer (CEO), Chief Financial Officer (CFO), Chief Information Officer (CIO)), ou pelo conselho de administração.

Afim de identificar os gestores apropriados e não limitar as atividades críticas de sourcing aos executivos, o termo gestores estratégicos é usado no eSCM-CL para referir-se aos líderes organizacionais que podem ter responsabilidade pelo patrocínio, apoio, direcionamento e revisão das atividades de sourcing (HEFLEY; LOESCHE, 2006).

\subsubsection{STR02 - Sourcing Constraints}

A prática STR02 - Sourcing costraints, ou restrições à iniciativa de sourcing, busca identificar as possíveis restrições que podem impactar os potenciais uso do sourcing.

Determinar as restrições que impactam como o sourcing é relevante, possível ou beneficial para as dimensões do negócio, cliente, financeiramente, tecnicamente, operacionalmente, em 
termos legais e regulatórios. Por isso que a organização cliente deve estar atenta às implicações estratégicas, políticas, e gerenciais da iniciativa de sourcing.

Contudo, a cultura da organização pode ser receptiva às atividades de sourcing ou pode haver atores que possuam interesse em limitar as opções de sourcing. Exemplos dessas questões incluem:

- Algumas agências governamentais não permitem que os fornecedores de serviços usem offshore sourcing;

- Alguns líderes organizacionais podem não estar preparados para gerenciar uma relação de sourcing ou os impactos organizacionais resultantes;

- Requisitos regulatórios podem impor limites na capacidade do cliente em transferir pessoal;

- O cliente pode ser muito pequeno para ter um gerenciamento efetivo de um fornecedor externo de serviços (HEFLEY; LOESCHE, 2006).

\subsubsection{STR03 - Potential sourcing areas}

A prática STR03 - Potential sourcing areas, ou áreas potenciais para sourcing, consiste em processos para decidir em que medida o sourcing pode ser relevante para a organização.

Determinar em quais situações o sourcing pode ser relevente para a organização cliente por meio da análise das estratégias e planos de negócios, da identificação de quais processos de negócio, competências são melhor executads por terceiros, deixando a organização concentrada nas competências centrais. O foco nas competências centrais, processos chaves, ou áreas estratégicas encoraja as organizações cliente a identificar e tomar vantagem do que eles sabem fazer de melhor, e alocar recursos para estar focado nas áreas de valor e crescimento. Competências periféricas podem ser mantidas nos casos em que um terceiro não pode executá-las por razões técnicas, políticas, econômicas ou tecnológicas.

Os clientes podem, também, identificar outras áreas de negócio nas quais o sourcing pode ser apropriado, tais como acesso a novas tecnologias ou transformação de processos para formas para sequiênciais ou mais eficientes. Nesses caos, o cliente deve escolher entre adotar o sourcing e outras opções (como, por exemplo, adotar uma nova tecnologia).

De uma forma geral, os clientes devem ter em mente os benefícios de negócio gerados pelas várias oportunidades e formas de relacionamento de sourcing, assim como cada uma dessas 
opções adequa-se aos objetivos de negócio (HEFLEY; LOESCHE, 2006).

\subsubsection{STR04 - Sourcing objectives}

A prática STR04 - Sourcing objectives, ou objetivos do sourcing, estabelece processos para definir, alinhar e documentar os objetivos da iniciativa de sourcing.

Estabelecer objetivos claros para a iniciativa de sourcing garante que as atividades a serem executadas estejam alinhadas com os objetivos de negócio e fornece meios de avaliar o desempenho do sourcing. O conjunto de objetivos deve refletir os motivos pelos quais a organização considera o sourcing uma estratégia de negócio apropriada. Por exemplo, em muitos caos, as organizações terceirizam um serviço com o intuito de obter um aumento da qualidade do serviço prestado com uma diminuição dos custos. Nesse caso, os objetivos fornecerão indicadores para gerenciar a avaliação do fornecedor. Esse processo deve envolver a organização de forma a garantir que o fornecedor mais capaz seja selecionado em termos de custos e qualidade. A organização pode definir objetivos relacionados com o desempenho do fornecedor de serviços; em alguns casos, esses objetivos podem definir quando o fornecedor de serviços deve manter ou aumentar os eu desempenho ao longo do ciclo de vida do relacionamento, ao passo que em outros relacionamentos os objetivos direcionem para manter o nível de desempenho e reduzir os custos.

Assim, é importante que a organização possua um entendimento claro dos seus objetivos de sourcing afim de estabelecer seus direcionamentos de longo-prazo e garantir o efetivo desenvolvimento, gerenciamento expansão de um relacionamento de sourcing de sucesso. Objetivos claramente definidos e mensuráveis estabelecem os princípios para a organização e permitem aos gestores estabelecerem expectativas de desempenho para as organizações. Esses objetivos são, geralmente, de longo prazo e são obtidos pela análise do ambiente organizacional (incluindo expectativas do cliente, competidores e tendências de negócio). Para ser efetivo, os objetivos de sourcing devem ser mensuráveis, e estar relacionados com necessidades dos stakeholders, além de estabelecer os níveis de desempenho desejados e esperados.

Os objetivos de sourcing devem ser claramente estabelecidos e apoiados, alinhados com objetivos de TI e de negócio, além de dar suporte ao alcance dos objetivos de negócio. os objetivos de sourcing podem ser usados como guias para o desenvolvimento de relacionamentos e acordos com os fornecedores. Pelo alinhamento com os objetivos estratégicos, os clientes podem garantir que os fornecedores possuam as capacidades necessárias para alcançar os objetivos estratégicos de sourcing e que os acordos sejam flexíveis o suficiente para adaptar-se as mudanças nos negócios, na tecnológica ou mesmo mudança nos objetivos organizacionais (HEFLEY; 
LOESCHE, 2006).

\subsubsection{STR05 - Organizational Sourcing Strategy}

A prática STR05 - Organization sourcing strategy, ou estratégia organizacional de sourcing, define processos para definir, comunicar e manter a estratégia de sourcing da organização.

Muitas organizações não criam uma estratégia de sourcing ligada aos seus objetivos e planos de negócios, tratando cada iniciativa como uma transação separada. A estratégia de sourcing é um elemento crucial e justifica-se pelo alinhamento das estratégias de negócio, TI, e sourcing. A estratégia de sourcing deve, claramente, direcionar a formulação dos objetivos de sourcing; deve estar alinhada coma estratégia de negócio, de crescimento e continuidade da organização; deve ter apoio da alta gestão; deve ser definida, documentada e seguida; deve ser constantemente atualizada em função das mudanças. No nível de capacidade 3, os objetivos de sourcing devem ser o fundamento para uma estratégia de sucesso de sourcing, e deve garantir o que a estratégia esteja alinhada com os objetivos de negócio. O conjunto dos objetivos de sourcing devem refletir os motivos pelos quais a organização considera o sourcing uma estratégia de negócio apropriada.

A estratégia organizacional de sourcing deve guiar a análise das atividades. Deve garantir que a organização analise quais capacidades (estratégias, core/non-core, processos chaves) devem ser mantidas internamente, assim como o impacto econômico de um potencial sourcing destas. Uma estratégia de sourcing deve determinar quais os papéis dos fornecedores na solução dos problemas atuais da companhia, na construção de um a infraestrutura, na execução dos serviços que mais satisfazem as necessidades da organização e atende seus objetivos futuros (HEFLEY; LOESCHE, 2006).

\subsubsection{Governance Management}

A área de capacidade de Gestão da governança (governance management) enfoca o desenvolvimento de estruturas organizacionais, processos e procedimentos necessários para uma fornecimento efetivo de serviços. Apesar de a área de gestão de governança ser focada nos aspectos relacionados à gestão da iniciativa de fornecimento de serviços, ela abrange, também, outras áreas de capacidade em diversos momentos do ciclo de vida (HEFLEY; LOESCHE, 2006). Por exemplo inclui: 
- Relationship management

- Organizational change management

- People management

- Knowledge management

- Technology management

- Threat management

- Sourcing agreements

- Sourced services management

- Sourcing completion

A área de capacidade GOV é composta por sete práticas:

1. Sourcing policy

2. Service provider management

3. Internal stakeholder management

4. Defined sourcing processes

5. Align strategy \& architectures

6. Business process interaction

7. Adapt to business change

\subsubsection{GOV01 - Sourcing Policy}

A prática GOV01 - Sourcing policy, ou política de sourcing, define processos para estabelecer e implementar a política organizacional de sourcing.

Uma política de governança de sourcing fornece as estruturas organizacionais, processos e mecanismos necessários para gerenciar, avaliar e melhorar as iniciativas de sorucing da organização além de dar apóio à estratégia de sourcing. Ao colocar em prática as capacidades organizacionais necessárias para construir, manter e governar fortes relacionamentos, os clientes estão aptos à descobrir novas oportunidades para criar valor dos seus relacionamentos de sourcing, 
e, também, estão aptos a extrair valor dessas oportunidades de forma mais efetiva e eficiente. Uma política de governança deve permitir a execução efetiva das atividades chave da iniciativa de sourcing da organização. Por meio da implementação de uma política de sourcing organizacional, as organizações podem garantir a consistência e confiança das atividades de governança das suas iniciativas de sourcing, e podem também transformar a governança dos seus relacionamentos em uma disciplina organizacional e estrutura de negócio que apoia o desenvolvimento contínuo do relacionamento com os fornecedores. Tal polícia deve demonstrar a liderança e comprometimento organizacional e é um fator chave de sucesso para a iniciativa de sourcing.

\subsubsection{GOV02 - Service Provider Management}

A prática GOV02 - Service provider management (Gerenciamento de fornecedores de serviço) define o processo de estabelecimento e implantação de procedimentos para gerenciar fornecedores de serviço.

Gerenciar fornecedores de serviços com a finalidade de dar suporte aos objetivos de sourcing da organização. Ter relacionamentos efetivos com os fornecedores auxilia a organização a aumentar suas capacidades e responder às mudanças das necessidades e demandas dos clientes internos.

O gerenciamento efetivo inclui o acompanhamento do desempenho dos fornecedores de serviços. O acompanhamento do desempenho dos fornecedores de serviços pode ser uma tarefa independente, mas é mais provável que seja parte do acompanhamento de entrega do serviço.

O gerenciamento do relacionamento deve, idealmente, ser proativo e colaborativo, estandos os clientes e fornecedores trabalhando em conjunto para resolver os problemas que surgem.

\subsubsection{GOV03 - Internal Stakeholder Management}

A prática GOV03 - Internal stakeholder management (Gerenciamento das partes interessadas internas) define os processos para estabelecer e implementar procedimentos para gerenciar as partes interessadas internas.

Gerenciar as partes interessadas internas com a finalidade de dar suporte aos objetivos de sourcing da organização. Ter procedimentos para gerenciar os relacionamentos com as partes interessadas interna auxilia a organização a garantir que os serviços fornecidos atendam suas necessidades e possam responder às mudanças das suas demandas. 


\subsubsection{GOV04 - Defined Sourcing Processes}

A prática GOV04 - Defined sourcing process (Processos de sourcing definidos) define processos para estabelecer e manter documentados os processos de sourcing dentro da organização.

Desenvolver e manter um conjunto de processos de sourcing documentados auxilia no aumento do desempenho dentro da organização, serve de guia para os funcionários nas suas atividades e fornece base para benefícios cumulativos de longo-prazo. Esses benefícios podem incluir atividades alinhadas com os objetivos e processos de negócio, atividades organizadas, controladas e verificadas pela gestão. Esses processos auxiliam a garantir que os mecanismos estejam disponíveis para serem empregados no gerenciamento do relacionamento com os fornecedores de serviços assim como atender os objetivos do cliente interno. Problemas podem ocorrer com qualquer relacionamento de sourcing em qualquer momento do ciclo de vida do acordo. Sem processos de sourcing apropriados, os problemas podem não ser identificados ou gerenciados adequadamente. Por outro lado, processos bem desenvolvidos e implementados permite que a organização integre e institucionalize as melhores práticas de planejamento, organização, aquisição, implementação, entrega, suporte e monitoramento do desempenho da iniciativa de sourcing afim e garantir o apoio as atividades do cliente interno e alcance dos objetivos de negócio.

\subsubsection{GOV05 - Align Strategy \& Architectures}

A prática GOV05 - Align strategy \& architectures (Alinhar estratégia e arquiteturas) define os processos para alinhar as estratégias e arquiteturas de modo a apoiar as iniciativas de sourcing na organização.

A estratégia e arquitetura organizacional voltada para os aspectos de infraestrutura, incluindo tecnologia, processos, aplicações e telecomunicações, fornecem a base para sustentação dos serviços baseados em TI. Os processo de negócio da organização fornecem a base para as operações diárias. Alguns desses processos podem ser terceirizados para um fornecedor de serviços. A medida que os serviços são terceirizados, os processos de negócios adaptam e mudam, e a tecnologia avança. Assim, torna-se responsabilidade do cliente manter uma estratégia e uma arquitetura que dará suporte aos seus serviços baseados em TI, assim como adaptar-se as mudanças geradas pelas pressões tecnológicas e de mercado.

A estratégia e os planos da organização para os seus processos de negócio e para a infraestrutura tecnológica que apóia a realização desses processos devem ser revistas de forma a confirmar a existência de uma forte ligação entre as estratégias de TI e de negócio. 
Os gestores devem garantir que as dificuldades e oportunidades sejam avaliadas de forma adequada e refletidas nos planos de curto e longo-prazo da organização. Esses planos devem ser desenvolvidos e mantidos de forma a garantir que a tecnologia e o negócio estejam alinhados com a estratégia organizacional de sourcing. A adoção de práticas de sourcing sem a devida garantia de que ela esteja consistentemente alinha da com a estratégia e arquitetura organizacional pode geral riscos significativos, gerando impacto na entrega e desempenho dos serviços além de introduzir dificuldades desnecessárias na transferência do serviço.

O monitoramento contínuo dos avanços tecnológicos e tendências regulatórias garantirão que a arquitetura tecnológica da organização esteja apta a dar suporte às necessidades dos processos de negócio. A arquiteratura organizacional dos processos de negócio e sua implementação tecnológica devem ser continuamente monitoradas para garantir a capacidade da organização para trocar informação de forma confiável e segura.

Garantir a integração das estratégias é um mecanismo para garantir o alinhamento horizontal. Essa prática é focada na garantia da integração entre as atividades de sourcing com a infraestrutura tecnológica e os processos de negócio da organização. Enfoca, também, o alinhamento das estratégias, planos e implementações da infraestrutura de tecnologia do cliente e dos processos de negócio por meio das atividades de sourcing.

\subsubsection{GOV06 - Business Process Integration}

A prática GOV06 - Business process integration (Integração dos processos de negócio) define processos para estabelecer e implementer procedimento para gerenciar a integração dos processos de negócio com os processos executados pelos fornecedores de serviços.

O fornecimento de serviços baseados em TI requer que os processos de negócio da organização cliente estejam finamente integrados com os processos executados pelos fornecedores de serviços uma vez que este tornam-se partes integrais da organização no momento da operação e pode tomar qualquer uma das responsabilidades possíveis na escala e escopo da operação. Os processos devem ser coordenados entre todas as partes envolvidas de modo a alcançar o desempenho e os níveis de serviço acordados. Essa integração pode ocorrer no nível das interfaces entre os processos ou pode ocorrer em uma integração mais pervasiva dos processos e de sua execução. O objetivo da integração dos processos de negócio é incorporar e reforçar a natureza colaborativa entre o cliente o fornecedor de serviços de forma a garantir a integração dos processos e das medidas de desempenho como um dos mecanismos para garantir o alinhamento horizontal. 


\subsubsection{GOV07 - Adapt to business Change}

A prática GOV07 - Adapt to business change (Adaptar as mudanças de negócio) descreve os processo para estabelecer e implementar guias para revisão e adaptação à mudanças.

As atividades de sourcing na organização precisam estar alinhadas com as necessidades estratégicas do negócio e avaliadas com base no andamento das operações. Como as necessidades de negócio mudam, as atividades de sourcing da organização devem ser reconfiguradas de forma a responder à condições de emergência. Conseqüentemente, a organização precisa trabalhar próxima aos seus fornecedores de serviços de forma a adaptar-se continuamente às mudanças de requisitos e novas necessidades. Os processos devem ser constantemente revistos e refinados para garantir que todas as atividades adicionem valor de forma apropriada. Para alcançar os benefícios máximos do sourcing, os clientes devem rever seus acordos e retificar qualquer questões que possa emergir em função das mudanças nas necessidades de negócio ou nas restrições ambientais.

\subsubsection{Relationship Management (eSCM-CL)}

As práticas associadas com a área de capacidade de gestão de relacionamento (relationship management, no modelo eSCM-CL, estão voltadas para o desenvolvimento e manutenção e relacionamentos de longo-prazo com os fornecedores de serviço. Todas as práticas ocorrem no momento ‘em andamento' (HEFLEY; LOESCHE, 2006).

Os principais desafios associados com essa prática são o gerenciamento das expectativas dos stakeholders, além do desenvolvimento e manutenção de confiança no relacionamento e garantia da efetividada das interações entre os stakeholders, gestão das diferenças culturais, e, sobretudo, gestão e monitoramento da satisfação do cliente e seus usuários finais (HEFLEY; LOESCHE, 2006).

A área de capacidade REL é composta por sete práticas:

\section{Service provider interactions}

2. Service provider relationships

3. Internal relationships

4. Issue management

5. Cultural fit 


\section{Collaborative relationships \\ 7. Innovative relationships}

\subsubsection{REL01 - Service provider interactions}

A prática REL01 - Service provider interactions (Interações com os fornecedores de serviços) define processos para estabelecer e implementar procedimentos para gerenciar as interações com os fornecedores de serviço.

Gerenciar as interações com os fornecedores de serviços de forma consistente afim de ter um entendimento comum das necessidades do cliente. A efetiva documentação das interações com os fornecedores permite a criação de um histórico do relacionamento, incluindo, um registro intensivo dos requisitos do cliente.

Desenvolver um ponto de contato comum auxilia na garantia da continuidade da comunicação. Estabelece redundância e garante a existência de um conjunto apropriado de capacidades disponíveis para interagir com os fornecedores. A equipe relacionamento com fornecedores pode ser formada antes do estabelecimento do acordo formal com o fornecedor. Essa equipe deve ser mantida durante todo o ciclo de vida da iniciativa de sourcing, contudo, o seus componentes podem ser alterados a cada fase do ciclo de vida. Além da equipe de relacionamento com fornecedores, pode existir outras pessoas que interajam com o fornecedor (por exemplo, os usuários finais). Contudo, a responsabilidade por garantir o gerenciamento do relacionamento cabe à primeira.

\subsubsection{REL02 - Service Provider Relationships}

A prática REL02 - Service provider relationships (Relacionamentos com fornecedor de serviço) define processos para estabelecer e implementar procedimentos para gerenciar o relacionamento com os fornecedores de serviços.

Desenvolver e gerenciar relacionamentos com os fornecedores de serviços com a finalidade de desenvolver relacionamentos de longo-prazo, e comunicar os requisitos e necessidades da organização para obter-se um claro entendimento destes. Ter procedimentos efetivos para gerenciar o relacionamento com os fornecedores auxilia a organização a comunicar suas necessidades e requisitos de sourcing e a determinar proativamente como estes podem corroborar para os objetivos de negócio.

A existência de interfaces entre a organização e seus fornecedores de serviço é fundamental 
para um resultado de sucesso. Para alguns, a iniciativa de sourcing significa delegar a responsabilidade final para um fornecedor. A realidade, contudo, é que a responsabilidade não pode ser delegada; a organização precisa gerenciar os seus acordos e relacionamentos. As interfaces entre o cliente e os fornecedores são, freqüentemente, complexas e devem ocorrer em diversos níveis ao longo do ciclo de vida de sourcing.

\subsubsection{REL03 - Internal Relationships}

A prática REL03 - Internal relationships(Relacionamentos internos) define processos para estabelecer e implementar procedimentos para gerenciar os relacionamentos com os clientes internos.

Gerenciar os clientes internos de forma consistente consiste em atingir um entendimento comum e compreensivo das necessidades dos clientes internos. A coleta, análise e acompanhamento das interações com os clientes permite a criação de um registro extensivo que pode fornecer insights sobre as necessidades e requisitos dos clientes internos.

Fornecer um ponto de contato comum auxilia o desenvolvimento da continuidade da comunicação e garante que existe um conjunto apropriado de competências disponíveis para interagir com os clientes internos e outras partes interessadas. A resistência à mudança freqüentemente ocorre quando indivíduos reagem à mudar, especialmente em situações onde sua informação é limitada ou possuem medo da nova situação. Um relacionamento confiável com os clientes internos é importante para superar essas barreiras da resistência interna.

Possuir relacionamentos efetivos com os clientes internos auxilia a organização a compreender as necessidades de mudança dos seus clientes e proativamente determinar como solucionar essas questões e ao mesmo tempo alcançar os objetivos de negócio. Ter relacionamentos efetivos auxilia, também, na compreensão das necessidades futuras e a posicionar suas capacidades para atender essas necessidades.

\subsubsection{REL04 - Issue Management}

A prática REL04 - Issue management (Gerenciamento de problemas) define processos para estabelecer procedimentos para gerenciar os problemas e sua resolução.

Problemas podem surgir em qualquer fase do ciclo de vida da iniciativa de sourcing e impact os relacionamentos entre as partes (usuários finais, organização, fornecedor, etc). O gerenciamento de relacionamento deve, idealmente, ser proativo e colaborativo com os clientes internos, fornecedores e parceiros trabalhando em conjunto para solucionar o problema. 
O gerenciamento de problemas cobre a identificação, documentação, escalação, negociação e resolução de disputas e conflitos entre as partes envolvidas na iniciativa de sourcing. Um gerenciamento efetivo de problemas requer que as técnicas que negociação e resolução de conflitos sejam padronizadas como um processo padrão de resolução de problemas.

Até mesmo em relacionamentos bem gerenciados os problemas surgem como um resultado de causas inevitáveis e imprevisíveis. Contudo, o que mais importa é como as partes envolvidas lidam com a questão de modo a não apenas a resolver os problemas, mas também a resolver disputas e conflitos. De modo a prevenir escalações desnecessárias, a organização deve definir e implementar um método comum de resolver de forma apropriada e diretamente os problemas que surgirem. Um bom método de resolução de problemas requer uma mudança de perspectiva da abordagem comum de tomar partidos para um método colaborativo de resolver os problemas em comum.

\subsubsection{REL05 - Cultural Fit}

A prática REL05 - Cultural fit (Ajuste cultural) estabelece processos para identificar atributos culturais que impactam o relacionamento e os serviços de sourcing, e implementar ações para alcançar o ajuste cultural.

Integrar as culturas da organização, do fornecedor e de outras partes envolvidas na relação de sourcing afim de dar suporte à coordenação necessário para atender os requisitos do cliente. Lidar com diferenças culturais também aumenta a satisfação das partes envolvidas e permite que todo o pessoal trabalhe efetivamente de forma conjunta.

As diferenças culturais que impactam o sucesso da entrega de serviços podem incluir diferenças lingüísticas, nacionais, regionais, organizacionais, estilos de tomada de decisão, atitude frente a horas de trabalho, fusos horários, disponibilidade de pessoal para as atividades de gestão, e diferenças nos valores. Se por um lado, não é sempre necessário ou apropriado solicitar ao fornecedor que adeque-se à cultura da organização, por outro é importante alcançar um nível de integração entre as duas culturas afim de efetivamente entregar o serviço. Em alguns caos, atributos culturais podem ser exigidos para a participação na iniciativa de sourcing (por exemplo, língua e sotaque são requisitos para contratos de call center). Em outros casos, o cliente e o fornecedor precisam aceitar as diferenças e identificar maneiras de trabalhar em conjunto (por exemplo, nos casos em que o cliente tem um estilo de tomada de decisão consensual e o fornecedor possui um estilo hierárquico). 


\subsubsection{REL06 - Collaborative Relationships}

A prática REL06 - Collaborative relationships (Relacionamentos colaborativos) define processos para estabelecer e implementar guias para o desenvolvimento de relacionamentos colaborativos com os fornecedores de serviço.

Estabelecer guias para desenvolvimento e fortalecimento de relacionamentos colaborativos com os fornecedores de serviços afim de proteger os interesses dos clientes, construir relacionamentos mais fortes, e aumentar as possibilidades de sucesso do fornecedor de serviço. Um ponto chave para gerenciar o sourcing com sucesso durante relacionamentos de longo-prazo é construir relacionamentos de confiança e colaboração, que ultrapassem os requisitos legais do acordo para explorar novos caminhos pelos quais os clientes e os fornecedores de serviços podem participar de atividades ganha-ganha. Essas atividades podem incluir dar acesso para os fornecedores aos recursos que eles necessitam para compreender e analisar as expectativas do cliente, dar treinamento aos fornecedores, envolvê-los nas reuniões de planejamento estratégico. A organização pode, também, investir no desenvolvimento de relacionamentos com os fornecedores atuais e futuros para desenvolver um entendimento comum dos interesses, capacidades e necessidades.

\subsubsection{REL07 - Innovative Relationships}

A prática REL07 - Innovative relationships (Relacionamentos inovadores) descreve processos para desenvolver relacionamentos que enfoquem a criação de valor por meio da inovação.

Desenvolver relacionamentos que encoragem os fornecedores a proativamente identificar e comunicar oportunidades de criação de valor, e trabalhar colaborativamente com os clientes para melhorar os processos criando valor para o cliente e para o próprio fornecedor. Um fornecedor que auxilia o cliente a atender seus objetivos de negócio contribuirá para a satisfação do cliente e pode ser visto pelo cliente como parceiro de negócio que agrega valor. O cliente pode identificar novas oportunidades de negócio com o fornecedor como resultado dessa interação.

"Criação de valor" refere a um aumento nos benefícios de negócio. No contexto desta prática, a criação de valor é mais do que adição de valor por meio da entrega do serviço já fornecido. Inclui o ato de identificar oportunidades que aumentam o valor para o cliente, incluindo inovações como novos arranjos de negócios ou novos avanços tecnológicos, bem como outras oportunidades para criar valor e realizar avanços.

O foco dessa prática é no desenvolvimento de confiança, adição de valor, e encorajamento da inovação, não apenas da perspectiva do fornecedor mas de todos os aspectos da organização 
envolvidos na iniciativa de sourcing. Inclui os relacionamentos com os fornecedores e com as unidades de negócio, e requer ênfase no desenvolvimento de gestão de relacionamentos como um responsabilidade para manter a parceria na medida em que elas se transformam em alianças estratégicas caracterizadas pelo compartilhamento de risco e lucros. Todas as partes possuem responsabilidade para manter o aspecto de parceria do relacionamento e atingir os objetivos de criação de valor e desenvolvimento de novas práticas inovadoras.

\subsection{Análise de conteúdo do modelo eSCM}

A análise de conteúdo do modelo eSCM foi realizada em três etapas. Inicialmente fez-se uma análise estrutural do texto afim de identificar sua estrutura lógica.

Em seguida, procedeu-se uma análise categorial visando identificar as principais categorias temáticas do texto das práticas selecionadas do eSCM.

E, finalmente, realizou-se uma análise textual buscando evidenciar as premissas explícitas e implicítas do modelo.

\subsubsection{Análise da estrutura textual}

O debate entre estrutura e significado, ou forma e conteúdo, constitui um dos eixos de discussão da teoria lingüística, estando, seus fundamentos filosóficos, presentes ao longo de toda a historia da filosofia. Algumas vertentes afirmam que a forma determina o conteúdo, outras postulam o oposto. O escopo dessa dissertação não compreende um aprofundamento dessa discussão. A despeito de tanto, acredita-se ser necessário uma breve descrição da estrutura textual do modelo eSCM uma vez que esta análise serve de fundamento para a identificação da estrutura lógica o modelo.

As unidades textuais do eSCM são as práticas. Cada prática constitui um conjunto de recomendações para um fator crítico de sucesso do sourcing. Por sua vez, a estrutura de cada prática é composta por três elementos distintos: a proposição (statement), a explicação e a descrição.

A proposição é o próprio título da prática, e descreve, de modo abrangente, a que temática aquela prática se destina.

A explicação consiste em um resumo dos processos, procedimentos, ou atividades que devem ser desempenhadas para que a prática seja operacionalizada.

A descrição consiste na apresentação dos processos, procedimentos e atividades propriamente 
ditos. Ainda que possuam recomendações distintas, todas as descrições das práticas seguem a mesma estrutura de argumentação normativa.

Tal argumentação associa o sucesso da prática com três elementos: apoio à criação e manutenção da prática; documentação e implementação dos processos, atividades e procedimentos; e, apoio à implantação da prática.

O apoio à criação e à manutenção da prática refere-se ao suporte necessário para a realização dos produtos e tarefas pretendidos, e constitui o primeiro passo do processo de implantação da recomendação. Por exemplo:

Provide support for creating and maintaining the organizational sourcing policy. $(\mathrm{GOV} 01)^{4}$

Provide support for creating and maintaining the procedures for managing issues and their resolution. (REL04)

Provide support for creating and maintaining the work products and tasks for developing and managing the sourcing strategy of the client organization. (STR05)

A documentação e implantação dos processos, procedimentos e tarefas das práticas é o rubrica central da estrutura das práticas. Nesta parte da descrição são expostas todas as etapas necessárias para a operacionalização da recomendação. Exemplificando, tem-se:

Document and implement the procedures required for managing service providers. Documentation and implementation include the following. (GOV02) Document and implement the procedures required for managing internal client relationships. Documentation and implementation include the following. (REL03)

Document and implement the work products and tasks required for developing and managing the sourcing strategy of the client organization. Documentation and implementation include the following. (STR05)

O terceiro e final elemento da estrutura das práticas é a recomendação para fornecer apoio a implantação da prática.

Support the implementation of managing internal stakeholders. (GOV04)

Support the implementation of managing issues and their resolution. (REL04)

Support the implementation of developing, aligning, and documenting sourcing objectives. (STR04)

\footnotetext{
${ }^{4}$ Todo o texto citado foi retirado do eSCM-CL. A prática a que ele se refere aparece entre aparece entre parênteses após o texto.
} 
Esta última difere-se da primeira no que aquela é a priori e esta é a posteriori.

Essa breve análise das estruturas textuais das práticas do eSCM revela uma lógica, necessária à implantação do modelo, fundamentada no apoio (financeiro, político, gerencial, etc) à implantação e à manutenção da prática e na documentação e implantação dos procedimentos descritos. A um primeiro olhar desatento, essa estrutura lógica pode parecer óbvia. Contudo, ela desconsidera que as organizações são entidades formadas por pessoas e possui grupos de interesse diferentes. Ainda que se consiga documentar e implantar os processos, o apoio à implantação e manutenção destas práticas é algo a ser continuamente buscado. Esses aspectos são críticos pois o patrocínio depende da negociação política, e a prática de documentação depende uma mudança cultural, especialmente em ambientes culturais que valorizam a informalidade.

\subsubsection{Análise categorial}

A análise categorial consiste no desmembramento do texto original e seu reagrupamento baseado em unidades semânticas, ou categorias temáticas. Para realização dessa atividade utilizouse o software QSR Nvivo $8^{\circledR}$.

$\mathrm{Na}$ análise categorial do corpus formado pelos textos das práticas do modelo eSCM buscou-se identificar as principais unidades semânticas das áreas de capacidade escolhidas (Governance management, Relationship management, Sourcing strategy management).

Encontrou-se um conjunto de seis unidades semânticas: planejar, definir, mapear, documentar, mapear, revisar, verificar. Essas unidades e seu detalhamento são apresentados na tabela 8.

\subsubsection{Planejar}

A unidade semântica planejar refere-se à função administrativa de estabelecer direcionamentos para o futuro. A literatura de administração diferencia que o planejamento em níveis como estratégico, tático e operacional. No contexto do eSCM, o planejamento refere-se a elementos táticos e operacionais, abrangendo elementos tais como os objetivos do sourcing, os processos necessário para o sourcing, as competências necessárias, e os papéis e responsabilidades dos atores envolvidos.

$\mathrm{Na}$ análise do modelo eSCM identifica-se o planejamento com a criação de planos, como em:

Create a plan to achieve a cultural fit. (REL05)

Create a plan for integrating the business processes. (GOV06) 


\begin{tabular}{|l|c|c|}
\hline Unidade semântica & Fontes & Referências \\
\hline Planejar & 6 & 8 \\
Objetivos & 4 & 4 \\
Processos, procedimentos e tarefas & 1 & 2 \\
Competências necessárias & 1 & 1 \\
Papéis e responsabilidades & & \\
\hline Definir & 9 & 13 \\
Critérios & 9 & 10 \\
Papéis e responsabilidades & 7 & 10 \\
Pessoas & 2 & 3 \\
Processos & & \\
\hline Mapear & 12 & 14 \\
Processos & 12 & 13 \\
Pessoas & 5 & 6 \\
Critérios & 3 & 3 \\
Riscos & 1 & 2 \\
Estratégias, planos, políticas & 1 & 1 \\
Infraestrutura & 12 & 21 \\
\hline Documentar & & \\
\hline Verificar & 10 & 13 \\
Andamento (follow up) & 8 & 10 \\
Alinhamento com objetivos e estratégias & & \\
\hline Revisar & 6 & 10 \\
Processos e documentação & 3 & 3 \\
Contrato & \\
\hline
\end{tabular}

Tabela 8: Relação das unidades semânticas encontradas na análise categorial das práticas selecionadas do eSCM. 
Em outras práticas, o processo de planejamento é detalhado. Em especial nas práticas de Sourcing Strategy Management, existem procedimentos como

Assess organizational capabilities for sourcing. (STR05)

Analyze current organizational capabilities to support sourcing (STR05)

Os aspectos mais valorizados no processo de planejamento são o planejamento de objetivos. Generalizando, todas os procedimentos devem ter um objetivo claro. Por exemplo:

Define objectives for the team interacting with internal stakeholders. (GOV03) Define objectives for interactions with service providers. (REL01)

Define relationship goals for each identified target. (REL02)

Outra preocupação do planejamento, no modelo eSCM, é o desenho de processos e procedimentos. Essa preocupação enfatiza uma verificação constante dos processos, existindo mesmo uma prática dedicada somente ao controle dos processos (GOV04 - Defined sourcing processes). Exemplos textuais dessa preocupação podem ser encontrados em:

Create a plan for verifying processes. (GOV04)

Sourcing objectives are addressed at appropriate levels in the organization.

- Sourcing objectives are addressed at appropriate levels in the organization by defining relevant functional, departmental, service, process, team, and individual objectives. Sourcing objectives may also include time frames for achieving the objectives. (STR04)

A leitura do planejamento no modelo eSCM é um foco na precisão e objetividade dos processos. Eles devem ter uma clara razão de existência, definida e documentada, associada com uma supervisão constante.

\subsubsection{Definir}

O termo definir é mencionado no texto em referência à necessidade de estabelecer ou de se determinar algum atributo ou objeto. Associado a esse, aparecem outros termos tais como critérios, papéis e responsabilidades ou pessoas e processos.

A definição de critérios aparece diante da necessidade de determinação de atributos para mensuração ou avaliação do fornecimento de sourcing. Por exemplo, em GOV02:

Determine the attributes of service provider relationships and performance to be tracked (GOV02).

Define criteria for determining relevance of sourcing.

e. Identify criteria for determining if the service or process is core competence 
of the organization or of strategic importance to the organization.

f. Identify criteria for determining if sourcing results in achievement of business and strategic objectives.

g. Identify criteria for determining the amount of risk the organization will tolerate related to sourcing the service or process. (STR03)

A definição de critérios aparece, também, associada com o processo de tomada de decisão, como em GOV03:

Define decision-making and prioritization processes.

Determine notification rules for each priority.

Neste último caso não é feita uma menção explícita acerca dos critérios, mas acerca de processos ou regras para priorização.

A definição de critérios aparece associada procedimentos, por exemplo, em REL01, a noção de critério aparece associada com um método para gerenciar a interação e escalação das interações entre fornecedor e cliente.

Define interaction handling and escalation methods.

a) Select and document methods to prioritize interactions.

b) Identify types of interactions that may require to be escalated.

c) Define decision-making and prioritization processes.

d) Determine notification rules for each priority.

e) Define how these interactions will be reported and communicated. (REL01)

Umas das questões presentes em diversos momentos do eSCM é sua preocupação com o estabelecimento de estruturas burocráticas. Um dos reflexos dessa preocupação burocrática é a definição de funções, papéis e responsabilidades organizacionais.

Em GOV01 é proposto que uma política de sourcing deve possuir definido e implementada as funções organizacionais:

Define and implement the organization?s sourcing functions.

a) Define key roles for the organization?s sourcing functions.

b) Define appropriate management controls for the organization?s sourcing activities.

c) Establish senior management guidance and review for the organization's sourcing functions.

d) Define mechanisms for reviewing the organizational structure for sourcing to continuously meet objectives and changing circumstances. (GOV01)

A mesma abordagem ênfase aparece em outras práticas: 
Identify the roles and responsibilities needed to meet the identified objectives. (GOV03)

Identify roles and responsibilities of relevant stakeholders. (GOV04)

Define roles, responsibilities and authorities for proposed changes. (GOV07)

Define the roles, responsibilities, and authorities of the organization?s contact personnel in regard to the sourcing relationship. (REL03)

Relacionado com a definição de papéis e responsabilidades, aparece a definição de competências e pessoas. O primeiro enfoca a definição de estruturas, esse enfoca a definição dos ocupantes dessa estrutura.

De acordo com a fase do processo de sourcing, é necessário definir e implantar a equipe responsável

Establish and implement the team for interacting with internal stakeholders. (GOV03)

Identify the personnel competencies required for the service provider interactions. (REL01)

As competências dessa equipe precisam ser definidas e revisadas periodicamente.

A necessidade de definir processos é expressa, em parte, pela visão burocrática que o modelo assume. No eSCM, processos devem definidos afim de operacionalizar as estratégias. Por exemplo, em GOV01 é colocada a necessidade de criar-se uma estratégia de gestão dos níveis de serviço. Para tanto, é necessário definir um processo para estabelecer e coletar os níveis de serviço.

a) Create the strategy for service level management.

b) Define a process for establishing and collecting service levels.

- This process could be accomplished by performing the following steps:

Look at existing service levels

Identify required metrics

Identify existing data

Document existing service level agreement metrics catalog (GOV01)

\subsubsection{Mapear}

Mapear, ou identificar, foi um tema freqüentemente encontrado. Foi, também, um tema que apresentou grande dificuldade analítica para categorização uma vez que possui grande similaridade com os dois anteriores, planejar e definir. 
Entendeu-se por mapear, o processo de identificação de elementos. Essa identificação, por vezes, é pré-requisito ou entrada para uma atividade de planejamento ou para uma atividade de definição de requisitos, processos, etc. Ou, ainda, associado com o monitoramento.

O tipo de mapeamento mais freqüentemente encontrado foi o de processos. A citação textual que melhor representa esse tema talvez seja, em GOV04:

Establish and maintain a set of sourcing processes and process assets for use across the organization. (GOV04)

Mas também, podem ser citados:

Identify and analyze process components required for integration. (GOV06)

Identify tasks needed for establishing and maintaining the relationships. (REL02)

Outro mapeamento que constatemente aparece é o mapeamento de pessoas. Isto é, a identificação de pessoas ou papéis centrais que devem ser monitorados.

Identify key contact personnel for the organization and selected service providers. (REL02)

Identify the internal functions and roles crucial to managing the relationship and service delivery for each sourced service. (REL03)

Identify the services and stakeholders who may benefit from the innovation. (REL07)

\subsubsection{Documentar}

Documentar é um temas centrais do modelo estando, mesmo, associado com a lógica do modelo: todos processos, atividades, interações devem ser documentadas.

Se a iniciativa de documentar e registrar todos os elementos é louvável, uma vez que, teoricamente, pode-se, então, estabelecer um controle perfeito. Por outro, pode-se degenerar em dois aspectos.

Por um lado, a preocupação em estar alinhado com o modelo e gerar todos os documentos e artefatos solicitados pode deixar de lado a atividade de gerenciamento em si, isto é, enfocar excessivamente o registro documental em detrimento do relacionamento inter-pessoal.

Por outro lado, pode-se gerar tanta informação que sua utilidade se perde. Um dos problemas dos sistemas de informação contemporâneos não é a falta de informação, mas o excesso (WURMAN, 2000). 


\subsubsection{Verificar}

Verificar é o tema associado com o estabelecimento de controle. Nas práticas estudadas dois tipos de verificação são enfatizados: a verificação de andamento das atividades (follow up e a verificação de alinhamento entre as atividades e os objetivos.

Nas práticas estudadas, a ênfase maior é dada aos controles de acompanhamento da execução das atividades.

Track service provider tasks, according to the defined tracking methods. (GOV02) Determine measures to track sourcing process performance. (GOV04) Track status and progress against the plan, according to the defined tracking methods. (GOV06)

O alinhamento entre o sourcing e a estratégia da organização, e entre a estratégia de sourcing e a operação deste aparece constantemente.

Identify the purpose of sourcing, consistent with the organization?s sourcing strategy, objectives, and constraints. (GOV01)

Ensure that the organization?s sourcing processes and process assets are consistent with, and integrated with, the business processes of the organization. (GOV04)

Verify that the relationship goals are aligned with organizational and sourcing objectives. (REL02)

\subsubsection{Revisar}

Se a verificação identifica desvios dos planos, faz-se necessárias revisões. Nas práticas estudadas o tema revisar aparece próximo do tema verificar.

A preocupação maior é a revisão de processos e sua documentação

Review tailoring of the process assets. (GOV04)

Review sourcing policies and processes for appropriateness, periodically or as business changes occur. (GOV07)

Em outras partes aparecem recomendações para uma revisão contratual.

Decide whether the proposed change is within the scope of the current agreement or whether it requires an amendment to the current agreement. (GOV07) Periodically review the agreement and the status of the relationship with each service provider, and take action as appropriate. (REL02) 
A análise categorial revela seis grandes categorias temáticas tratadas nas práticas estudadas do modelo eSCM (planejar, definir, mapear, documentar, verificar e revisar). Comparando-se essas categorias com a literatura de administração, é possível afirmar que modelos de qualidade foram usados como base inspirativa para o eSCM. Uma primeira leitura remete essas unidades semânticas para o modelo PDCA.

O modelo PDCA (Plan-Do-Check-Action) é um dos primeiros modelos de controle de qualidade desenvolvido no pós-guerra, e compreende quatro etapas (MAXIMIANO, 2000):

1. Plan-compreende o estudo de um processo e o planejamento de seu aprimoramento;

2. Do - é a implementação da mudança;

3. Check - é a observação dos efeitos da mudança;

4. Action - é o estudo dos resultados.

Uma comparação entre as unidades semânticas das práticas do eSCM e o ciclo PDCA é apresentada na tabela 9.

\begin{tabular}{|c|c|}
\hline Unidade semântica & Etapa do ciclo PDCA \\
\hline Planejar & Plan \\
\hline Definir & Plan \\
\hline Mapear & Plan \\
\hline Documentar & Check \\
\hline Verificar & Action \\
\hline Revisar & Do \\
\hline
\end{tabular}

Tabela 9: Comparação entre as unidades semânticas identificadas na análise categorial do eSCM e as etapas do ciclo PDCA.

\subsubsection{Análise das premissas explícitas do modelo eSCM}

As premissas do modelo são as proposições que fundamentam sua estrutura. Algumas delas podem ser explícitas, outras não. A identificação e análise das premissas do modelo é uma etapa essencial para compreender sua adequação, uma vez que cientes da existência desses pressupostos torna possível discutir sua factibilidade.

De uma análise criteriosa do texto depreende-se algumas das premissas do modelo eSCM que aparecem explicitamente. Dentre as quais: 
Premissa 1: A excelência e o sucesso da iniciativa de sourcing estão associados com a adequação às recomendações do eSCM.

A premissa inicial do eSCM é que a sucesso da iniciativa de sourcing está associado com o emprego do modelo eSCM. Tem-se uma afirmação de que adoção de processos padronizados de governança implica no sucesso. Essa premissa aparece diversas ao longo do texto, estando o eSCM sempre associado com o sucesso. Por exemplo, no primeiro volume do modelo eSCMCL é descrito que:

The eSCM-CL is composed of 95 Practices, which can be thought of as the "best practices" that are associated with successful sourcing relationships. (HEFLEY; LOESCHE, 2006, p. 82)

Certamente, não é possível negar que o modelo traga contribuições para uma melhor gestão do sourcing. Contudo, associar tal sucesso somente às práticas propostas pode ser um visão ingênua ou simplista, uma vez que são desconsiderados fatores exógenos à gestão. Além de assumir a validade universal do modelo eSCM.

Um outro ponto de crítica a essa premissa é que ela assume a validade universal do eSCM. Por mais que o modelo eSCM traga benefícios, sua validade é restrita à determinados contextos.

Premissa 2: Deve existir uma objetividade das decisões, as quais devem ser baseadas em critérios.

A segunda premissa explícita do modelo é acerca do processo decisório nas diversas etapas da iniciativa de sourcing. O modelo eSCM postula a necessidade de objetividade e clareza das decisões, qualidades estas que podem ser obtidas por meio da fundamentação em critérios igualmente claros e objetivos. Por essa razão que em diversos momentos o modelo ressalta a necessidade de identificar, planejar e coletar critérios.

Essa premissa possue uma fundamentação ontológica que prescreve uma possibilidade de objetividade e clareza dos critérios.

Premissa 3: As atividades da operação de terceirização devem ser documentadas e formalmente descritas, informando os papéis e as responsabilidades.

Enfatizando a necessidade de se documentar todos os processos, atividades e tarefas do sourcing, identifica-se uma premissa influenciada pelos ideais de controles burocráticos, na qual quanto mais documentado for uma atividade melhor ela é.

Premissa 4: A hierarquia de comando e relacionamentos devem ser claros e objetivos.

Similarmente ao controle dos processos, identifica-se uma premissa de estabelecer hierarquias 
claras. Isto é, a divisão de trabalho entre os diversos níveis deve estar bem definidos.

Simultaneamente, o modelo eSCM estabelece, também, uma necessidade de deixar os relacionamentos claros.

Premissa 5: As estratégias de sourcing e de negócio devem estar alinhadas entre si.

O desenvolvimento das atividades de sourcing deve estar alinhado com os objetivos e estratégias da organização.

Premissa 6: A arquitetura tecnológica e as estratégia de sourcing devem estar alinhadas.

A operação de TI, e toda a infra-estrutura necessária para o seu funcionamento, deve estar alinhada aos objetivos de sourcing.

\subsubsection{Análise das premissas implícitas no modelo eSCM}

Se algumas premissas aparecem explicitamente no texto, outras precisam ser deduzidas. Estas encontram-se ocultas no discurso e são associadas com as crença e valores dos criadores do modelo.

As premissas anteriores estavam claramente expressas no texto, ao passo que essas foram deduzidas pelo pesquisador durante o processo de análise.

\section{Premissa 7: Racionalidade instrumental.}

O modelo eSCM faz um importante proposição acerca dos agentes envolvidos no sourcing: eles são dotados de um modelo mental com racionalidade instrumental. Essa perspectiva reflete uma projeção utilitarista na tomada de decisão, a qual pode ser concebida como um problema de maximização do valor (econômico, político, etc). Adicionalmente, a racionalidade instrumental assume a possibilidade de obter informações perfeitas e completas no processo decisório e que o agente seja plenamente capaz de tomar a decisão.

Um exemplo dessa premissa aparece na prática STR02, na qual é descrito o processo de identificar restrições ao sourcing.

2. Analyze identified potential sourcing constraints.

a. Determine the impact of identified potential sourcing constraints on sourcing and organization.

b. Identify mechanisms to overcome the identified potential sourcing constraints.

c. Identify resources and competencies required for overcoming the identified potential sourcing constraints.

d. Identify resources and competencies available for overcoming the identified 
potential sourcing constraints.

e. Analyze the organizational capability to bridge the gap between required and available resources and competencies for overcoming the identified potential sourcing constraints.

Nesse processo decisório, em nenhum momento, os autores fazem menção à impossibilidade de se obter essas informações de forma acurada ou acerca da incompleteza destas.

A adoção de uma racionalidade instrumental para os agentes está associada com outra premissa: a escolha de um desenho organizacional de acordo com as formas prescritas pela teoria clássica.

Premissa 8: A comunicação privilegia a transmissão unilateral de informação.

Reconhecendo que a comunicação é um fator importante do processo de gestão do sourcing, o modelo eSCM dedica várias menções a este elemento. Contudo, a comunicação é compreendida como o procedimento de transmissão de informações aos atores relevantes por meio canais adequados de comunicação.

A ênfase é dada ao ato de transmitir a informação, por exemplo:

Communicate the organization's sourcing policy to stakeholders. (GOV01)

Communicate the sourcing processes and implementation plan to relevant stakeholders. (GOV04)

Communicate the plan to relevant stakeholders. (GOV06)

Communicate agreed-upon guidelines to relevant stakeholders. (REL02)

Os atores da comunicação são elementos centrais:

Communicate information about the client organization's business objectives, sourcing strategy and objectives to appropriate personnel. (REL07)

Communicate identified opportunities, business cases, and impact analysis to relevant stakeholders. (REL07)

Communicate sourcing strategy to relevant stakeholders. (STR05)

Os canais de comunicação devem ser adequados às funções e papéis:

Provide regular channels of communication with the identified functions and roles.

a) Identify preferred communication methods and media for each contact.

b) Select or develop standard tools for managing the relationship.

c) Communicate the information and relationship management mechanism to each contact.

d) Coordinate communications between the internal contacts and the service provider, as appropriate.

e) Identify and make available the information required by the internal contacts.

f) Obtain feedback from contacts on the status of the relationship (REL 03) 
A necessidade de um retorno (feedback) aparece em alguns contextos, por exemplo:

Obtain feedback from contacts on the status of the relationship. (REL 03)

Obtain feedback on cultural fit achieved from relevant stakeholders, modifying the plan as appropriate.

a) Obtain stakeholder feedback on effectiveness of actions taken to achieve a cultural fit.

b) Analyze stakeholder feedback.

c) Modify plans to achieve a cultural fit, based on feedback received. (REL05)

Premissa 9: A relação informal limita-se à lembrança de datas e preferências dos indivíduos.

O modelo eSCM reconhece a existência de aspectos informais nas relações de sourcing. O modelo argumenta que essas atitudes são necessárias para se desenvolver atitudes cooperativas dos parceiros.

Establish relationships with the service provider's contact personnel.

Relationships have formal and informal aspects. While the organization and the service provider often explicitly recognize the formal aspect (e.g., an account lead is assigned as a point of contact to a service provider executive), it is often advantageous to supplement this with informal relationship building (e.g., finding out about service provider personnel?s personal interests and hobbies, or keeping a record of service provider birthdays and special events) to foster good will.

Premissa 10: Os conflitos são tratados explicitamente.

Ao assumir a impessoalidade do modelo, assume-se também que os conflitos dentro da relação de sourcing são explícitos, e podem ser resolvidos por meio de procedimentos administrativos.

Create issue and dispute handling and escalation methods for service providers. (GOV02)

Define issue handling and escalation methods for internal stakeholders. (GOV03)

\section{Premissa 11: O controle ocorre pela estrutura organizacional.}

Um dos principais pilares do eSCM está na prática de formalização e documentação de todas as atividades e processos.

Premissa 12: A segurança institucional garante os direitos de propriedade.

Uma importante premissa assumida pelo modelo eSCM é a existência de segurança institucional para garantia dos direitos de propriedade, o que dispensa outros mecanismos de resolução de conflito. 


\subsection{Análise comparativa do eSCM com o ambiente institucional brasi- leiro}

Nas análises anteriores foram empregas as técnicas da análise de conteúdo para identificação das premissas implícitas e explícitas do modelo eSCM. Obtidos estes resultados, passa-se à discussão da adequabilidade e conseqüências de cada premissa no contexto institucional brasileiro. Toma-se como referência os modelos de características apresentados no capítulo 4.

Cada uma das dozes premissas anteriormente enunciadas são comparadas com as características do ambiente institucional brasileiro. Na tabela 10 são apresentadas as características mais críticas para cada hipótese.

Premissa 1: A excelência e o sucesso da iniciativa de sourcing estão associados com a adequação às recomendações do eSCM.

O modelo eSCM se assume como critério suficiente para o sucesso do sourcing. A priori, não é possível aceitar tal premissa sem evidências empíricas dessa relação. Entretanto, essa premissa, considerada no nível do discurso apresenta um forte potencial de interação com a característica de plasticidade e permeabilidade da cultura gerencial brasileira.

Um forte atrativo (o sucesso garantido do sourcing) pode ser o chamariz necessário para que a prática seja adotada nas organizações. Contudo, ao mesmo tempo que o brasileiro é permeável, ele também é plástico. Essa plasticidade faz com que o brasileiro adapte o modelo as suas características.

Essa adaptação pode ser crítica, uma vez que remove a disciplina necessária para a implantação do proposto.

Uma segunda potencialidade de interação é no tangente às estruturas. O modelo eSCM preconiza a definição e implantação de estruturas organizacionais claras. Paralelamente, a cultura gerencial brasileira é, também, influenciada por estruturas, mas com uma conotação negativa.

Essa negatividade é derivada do estilo gerencial autoritário e marcado pela distância de poder e centralidade das decisões.

Se o eSCM busca as estruturas para ter clareza das relações, a cultura brasileira precisa das estruturas para manter as relações de poder. Assim, mantém-se nas organizações a regra de "manda quem pode, obedece quem tem juízo". A associação entre esses dois fatores pode levar a institucionalização, por meio de estruturas organizacionais, das relações de poder com caráter escravocata. 


\begin{tabular}{|l|l|}
\hline Premissa & $\begin{array}{l}\text { Espeficidade do ambiente instituci- } \\
\text { onal relacionada }\end{array}$ \\
\hline $\begin{array}{l}\text { 1. A excelência e o sucesso da iniciativa de sourcing } \\
\text { estão associados com a adequação às recomendações } \\
\text { do eSCM }\end{array}$ & Plasticidade e permeabilidade \\
& $\begin{array}{l}\text { Estilo gerencial autoritário } \\
\text { Estrutura organizacional rígida }\end{array}$ \\
\hline $\begin{array}{l}\text { 2. Deve existir uma objetividade das decisões, as } \\
\text { quais devem ser baseadas em critérios }\end{array}$ & Ambigüidade \\
\hline $\begin{array}{l}\text { 3. As atividades da operação de terceirização de- } \\
\text { vem ser documentadas e formalmente descritas, in- } \\
\text { formando os papéis e as responsabilidades }\end{array}$ & Formalismo e "faz-de-conta" \\
\hline $\begin{array}{l}\text { 4. A hierarquia de comando e de relacionamento de- } \\
\text { vem ser claros e objetivos }\end{array}$ & Personalismo \\
\hline $\begin{array}{l}\text { 5. As estratégias de sourcing e de negócio devem } \\
\text { estar alinhadas entre si }\end{array}$ & Astratégia pouco focada \\
\hline $\begin{array}{l}\text { 6. A arquitetura tecnológica e as estratégia de sour- } \\
\text { cing devem estar alinhadas }\end{array}$ & Estratégia pouco focada \\
\hline $\begin{array}{l}\text { 7. Racionalidade instrumental } \\
\text { de informação }\end{array}$ & Estilo gerencial autoritário \\
\hline $\begin{array}{l}\text { 9. A relação informal limita-se à lembrança de datas } \\
\text { e preferências dos indivíduos }\end{array}$ & Formalismo e "faz-de-conta" \\
\hline 10. Os conflitos são tratados explicitamente & Plasticidade \\
\hline propriedade & Estrutura organizacional rígida \\
\hline
\end{tabular}

Tabela 10: Comparação entre as premissas identificadas na análise de conteúdo do eSCM e as especificidades do ambiente institucional associadas. 
Por essas características, o modelo eSCM pode tornar-se apenas um modelo de "faz-de-conta". Ele é adotado no discurso, mas não é implantado na prática.

Essa premissa possui um problema lógico, pois assume a governança como fator suficiente para o sucesso da iniciativa de sourcing. A experiência prática mostra que além da gestão outros fatores ambientais e institucionais afetam o sucesso.

Premissa 2: Deve existir uma objetividade das decisões, as quais devem ser baseadas em critérios, também, objetivos.

A conformância aos regulamentos é o ideal burocrático. Contudo, sua interação com a característica de ambigüidade pode ter resultados perversos. Motta e Alcadipani (1999) descrevem o exemplo da "operação padrão" realizada por funcionário do serviço de trens metropolitano de São Paulo. Geralmente os trens operam com pequenas irregularidades, tais como falhas elétricas, ausência de extintor em todos os vagões, e outros. Nas operações padrão, os funcionários observam rigorosamente todos os critérios necessários ao funcionamento do sistema ferroviário, o resultado é que o sistema de transporte da cidade entra em pane.

Premissa 3: As atividades da operação de terceirização devem ser documentadas e formalmente descritas, informando os papéis e as responsabilidades.

O formalismo prescrito por essa premissa do modelo eSCM pode interagir com o formalismo típico da cultura brasileira e gerar um comportamento "faz-de-conta". Isto é, as atividades são documentadas e formalmente descritas, contudo a prática é outra.

Premissa 4: A hierarquia de comando e de relacionamento deve ser clara.

A hierarquia preconizada pelo modelo eSCM visa a objetivação das relações sociais. Contudo, no Brasil, as relações são ambíguas por natureza dado a intersecção das dimensões pessoais e profissional.

Essa ambigüidade pode ser associada com a características do personalismo, e ocorrer tráfico de influência, prática bastante comum no serviço público.

Por outro lado, a hierarquia preconizada pelo modelo eSCM pode corroborar para a manutenção das estruturas rígida de poder existentes na cultura nacional.

Premissa 5: As estratégias de terceirização e de negócio devem estar alinhadas entre si. Premissa 6: A arquitetura tecnológica deve estar alinhada com as estratégias.

As premissas 5 e 6 propõe um alinhamento entre o negócio, o sourcing e a tecnologia. Essa proposta de racionalização da operação encontra um desafio na característica cultural de um estratégia pouco focada. $\mathrm{O}$ alinhamento pressupõe a existência de um planejamento de longo prazo, 
elemento nem sempre presente nas organizações brasileiras ou de caráter duvidoso, quando presente.

\section{Premissa 7: Racionalidade instrumental.}

Não é possível fazer uma comparação da premissa de racionalidade instrumental com o modelo de especificidades da cultura brasileira. Contudo, essa premissa, como apontado no capítulo 3, impõe uma forte restrição sobre o comportamento dos agentes, inexistindo no mundo real.

Premissa 8: A comunicação privilegia a transmissão unilateral de informação.

O modelo eSCM ao enfatizar a comunicação como transmissão unilateral de informação abre espaço o surgimento de ruídos no processo comunicativo. Essa tendência tende a agravar-se dentro de um contexto ambíguo.

Premissa 9: A relação informal limita-se à lembrança de datas e preferências dos indivíduos.

O modelo eSCM avança, em relação a outros modelos, ao reconhecer a informalidade. Contudo, sua visão é por demais simplista. A mera lembrança de datas comemorativas, no contexto brasileiro, pode representar uma atitude falsa do agente social. Uma mera atitude formal.

Os laços de informalidade, no contexto cultural brasileiro, envolvem aspectos pessoais mais profundos.

Premissa 10: Os conflitos são tratados explicitamente.

O modelo eSCM pressupõe uma lógica onde os conflitos nos relacionamentos podem ser claramente explicitados e tratados. No ambiente institucional brasileiro, os conflitos são velados. Dada à característica de plasticidade, amoldamos-nos à conviver com a contradição sem, necessariamente, resolvê-la.

Premissa 11: O controle ocorre pela estrutura organizacional.

Essa premissa do modelo poderia ser melhor conceitualizada como o controle não ocorre somente pela estrutura. Em contexto onde a estrutura organizacional caracteriza-se pela rigidez, desenvolvem-se, também, mecanismos sociais que atuam como engrenagens

Premissa 12: A segurança institucional garante os direitos de propriedade.

O eSCM foi desenvolvido dentro do contexto institucional norte-americano no qual o funcionamento das instituições, ainda que tenham falhas, é superior ao brasileiro. A possibilidade de execução dos contratos é mais real do que no nosso ambiente. Assumir essa premissa pode ser particularmente difícil, especialmente uma vez que o modelo não fala em mecanismos alternativos de solução de disputa. 


\subsection{Validação das análises}

Afim de validar as premissas e as análises foram realizadas três entrevistas com especialistas.

\subsubsection{Caracterização dos especialistas}

O especialista A é um renomado consultor no mercado de tecnologia brasileiro. Tendo várias publicações sobre o assunto, também possui experiência no meio acadêmico e experiência como CIO em várias organizações. Foi realizada uma entrevista presencial, gravada, com duração de aproximadamente uma hora. A transcrição totalizou um total de 15 páginas

O especialista B é sócio-diretor de uma consultoria especializada em gestão de TI. Foi diretor regional para Ásia e América Latina de um grande instituto de pesquisa de TI. Na sua experiência consta mais de uma centena de projetos. Foi realizada uma entrevista presencial, gravada, com duração de aproximadamente uma hora. A transcrição totalizou um total de 13 páginas

O especialista C é um especialista na implementação de eSCM, trabalha em um centro autorizado pelo ITSqc para certificação em eSCM. Por motivos de indisponibilidade de agenda, essa entrevista foi realizada por e-mail. O nível de profundidade foi menor que o das anteriores, uma vez que a possibilidade de interação foi menor. Cabe destacar que esta foi a última entrevista, na qual foi enfatizados alguns pontos ainda em aberto após as entrevistas anteriores.

\subsubsection{Validação do modelo cultural}

Antes de se validar as análises realizadas, procurou-se validar o modelo de características culturais adotado na pesquisa. O modelo foi enviado com antecedência para os três informantes.

De um modo geral todos acreditam que o modelo é válido e correto, porém limitado. Ao longo das entrevistas realizadas foram citados vários aspectos que restringem o modelo de características culturais baseado em características nacionais.

A sujeição à marcos regulatórios, como Sarbannes-Oxley Act, Basiléia II e outros, é um fator que impõe a adoção de metodologias de governança para a organização como um todo, e TI não é uma exceção. A adoção dos modelos acaba tornando-se algo necessário para a sobrevivência da organização. E como essas normas estabelecem procedimentos a serem seguidos, não há espaço para influência dos aspectos culturais. Como destaca A:

Apesar de eu concordar com todas essas características do ambiente institucional e cultural, ok? Eu acho que, na realidade, tem um ambiente de controle 
que está surgindo aí que favorece, independente, talvez, até das características do ambiente cultural. (A) ${ }^{5}$

Os marcos regulatórios podem estar sendo adotado por transformações nas organizações. Empresas que passam a atuar nas bolsas de valores precisam ter um nível de transparência maior. Nos setores em que a TI é um dos gastos importantes, aparecem, então, novos níveis de controle.

E isso ajuda também, porque você está indo para ambientes controlados, ambientes onde existe mais formalismo do ponto de vista institucional, de controle, de controle externo, vai para uma bolsa, por exemplo, vai para o novo mercado, vai para NASDAQ, vai para Nova Iorque. Tudo isso é um ambiente de controle. (A)

Já nas empresa que não estão sujeitas a essas restrições, as características culturais manifestamse de modo mais intenso. Por exemplo, o processo de contratação segue uma lógica mais informal, baseada em relacionamentos:

Talvez as organizações que não estejam obrigadas a esse ambiente de controle, talvez, aí você tenha um personalismo muito grande (...), o cara contrata porque é teu amigo, porque te conhece, porque tu tem credibilidade, já tem relacionamento. (A)

A limitação do modelo cultural pode estar associada com a origem da organização. Em empresas multinacionais os fatores culturais locais não afetam a contratação, uma vez que os acordos são definidos na matriz e impostos as filiais.

o grande desafio dos CIOs é gerenciar os contratos, porque são contratos mundiais e nem sempre o contrato mundial atende o regional. As vezes o cara tem que seguir, mesmo pagando três vezes mais, mas ele tem que seguir porque é um contrato mundial. (A)

O modelo cultural baseado em uma cultura tipicamente brasileira talvez não seja válido dentro de empresas nacionais fundadas por estrangeiros. Principalmente no Sul e Sudeste do Brasil, onde vários imigrantes (Alemães, Italianos, Japoneses, e outros) fundaram vários conglomerados, as organizações carregam traços da sua fundação os quais podem ser distintos da matriz afro-lusitana que marca a formação brasileira.

Eu acho que é muito difícil traçar um perfil, o quanto que a cultura brasileira afeta os negócios. Pois os negócios estão muito alinhados, também, com a influência cultural da empresa, do seu fundador, do local de origem da empresa. (B)

\footnotetext{
${ }^{5} \mathrm{O}$ autor da citação aparece entre parênteses.
} 


\begin{tabular}{|c|c|}
\hline Fase & Característica cultural influente \\
\hline Estratégia (Por quê terceirizar?) & Estratégia focada curto prazo \\
\hline Seleção (Quem? Como?) & Personalismo \\
\hline Implantação & A cultura modifica a percepção sobre a execução do serviço \\
\hline Manutenção & A cultura influência o relacionamento \\
\hline
\end{tabular}

Tabela 11: Influência cultural nas diversas fases do sourcing. Elaborado com base na entrevista com B.

Traços da cultura nacional podem ser suprimidos por traços da cultura específica do grupo a que o indivíduo pertence. No segmento de TI é possível identificar tipos culturais de acordo com a área de atuação do profissional.

(...) dentro de TI você tem três grandes culturas. Você tem a cultura o pessoal de sistemas, você tem cultura do pessoal que faz a interface entre TI e negócio e você tem a cultura do pessoal da área de produção e suporte. São culturas diferentes. O pessoal de produção e suporte, como estão mais acostumados a lidar com granularidade e controles, com eles é mais fácil implementar. (A)

A influência cultural manifesta-se de forma distinta nas diversas fases do processo de sourcing, sendo mais presente na gestão e menos na contratação.

A cultura na contratação é pouca, influência na gestão. As empresas tem buscado processos de contratação mais eficientes e padronizados. (A)

De acordo com a fase do sourcing, as características culturais brasileiras manifestam-se de forma distinta. Na tabela 11 são as apresentas as principais influências, por fase do processo de sourcing, na visão do informante B.

Na etapa de formulação da estratégia de sourcing, onde se definem quais serviços serão fornecidos, um fator cultural que influência é ausência de uma visão de longo-prazo, a ausência de uma visão estratégica.

Isso está muito relacionado com o que você já capturou aqui, das características do ambiente brasileiro, que é a questão de não ter um foco em estratégia. Como as coisas mudam a toda hora, eu fico com medo, por exemplo, de terceirizar e perder o controle. Isso, a gente ouve muito de empresa brasileira, essa preocupação com o controle. E, essa preocupação com o controle é porque se eu não estiver no comando na hora em que mudarem as coisas, o quê é que eu vou fazer? (B)

No momento da seleção do fornecedor os fatores culturais influenciam. Por não se ter estruturado o acordo, a seleção é realizada com base na rede de contatos do cliente. A segurança na escolha do fornecedor provém do relacionamento interpessoais. 
(...) também por aspectos culturais, eu vou comprar de quem eu confio. Então eu compro do amigo, tá certo? O amigo pode ser uma empresa local pode ser uma empresa multinacional, mas eu compro por outro fator. Em nenhuma dessas situações eu estruturei o meu deal. (B)

$\mathrm{Na}$ implantação e operação do serviço, as características culturais influenciam a percepção das partes sobre a responsabilidade de cada um na prestação dos serviços. Nas culturas de influência anglo-saxônicas, o serviço é o que foi acordado

Numa cultura americana, e é a forma como se estrutura os manuais de outsourcing que você vai encontrar, é o seguinte: o fornecedor diz "eu estou cumprindo meu SLA", o cliente brasileiro reclama "O SLA diz que eu tenho 12 horas para você resolver o problema, mas eu preciso que você resolva o problema hoje.", que acaba recebendo uma resposta como "Não, hoje não. Eu tenho 12 horas para resolver o problema". E aí começam a criar os conflitos. (B)

Em contraponto, nas culturas latinas o contrato é um mero instrumento formal. O relacionamento é muito mais importante:

Na hora que eu tenho problema em uma cultura italiana, você tem que resolver o problema. Você não é o meu parceiro? Eu não quero saber se você vai gastar, se você vai ter prejuízo, se não vai. Eu espero que você resolva o problema primeiro, e a gente vai conversar sobre quanto isso custou depois. (B)

A própria implantação das práticas tende a ser falhas. Para atingir o sucesso apregoado, é necessário que seja adotada todo o modelo lógico de processos prescritos. A não adoção de uma pequena parte pode invalidar, ou diminuir os resultados, do todo. Por exemplo, no caso da adoção de ITIL:

No ITIL, a gente tem visto esse tipo de problema. O cliente instala bem os processos de incident management, na hora que a gente faz um levantamento, ele está bastante aderente ao problem management. Mas ele não faz aquela partezinha final do problem management que é analisar a causa raiz e agir para corrigir, para eliminar as causas. Então, o quê que adiantou? Você colocou todas essas práticas, padronizou isso tudo. Teve algum ganho, mas o grande ganho que era eliminar a causa raiz dos seus problemas você não está eliminando porque aquela parte ninguém sabe fazer, ninguém implementou. Ou "isso é aí é muito complexo, isso aí é coisa só para americano". Então a gente tem uma deficiência de implantação. (B)

Finalmente, vale destacar que a sociedade brasileira está passando por um processo de transformação. Certamente com a globalização, a entrada de novos concorrentes estrangeiros e a atuação das organizações brasileiras em mercados externos, as características culturais estão se transformando. Essa caracterização foi realizada com base em autores da década de 1930 
(Gilberto Freyre, Sergio Buarque de Holanda) e das décadas de 1970/1980 (Darcy Ribeiro, Roberto DaMatta), ambos períodos em que o criticismo e esquerdimo era predominante no meio intelectual. Tomando essas considerações é importante observar a análise de C:

Concordamos parcialmente com o descrito. As características apontadas em sua análise retratam um lado negativo e, em nossa opinião, muitas empresas estão em fase de transição para um modelo mais próximo ao abordado no eSCM - com foco mais estratégico e preocupado com bons relacionamentos internos e externos. (C)

Ainda assim, essa caracterização permanece válida, pois como destaca B:

Eu não sei dizer se ela é completa. Mas que ela é correta, sim. (B)

\subsubsection{Validação do modelo eSCM}

Um dos questionamentos levantados no transcorrer da pesquisa é a validade da escolha do eSCM, ou de outro modelo qualquer que fosse. Esse questionamento é compartilhado pelos informantes, por diversas razões.

Ainda que os diversos modelos para governança de TI e governança de sourcing sejam interessantes, os gestores de TI nas organizações não estão preocupados com as siglas e sim com os resultados que serão obtidos.

(...) o pessoal não está preocupado com o modelo em si (...) eles [os CIO $]^{6}$ querem é ter uma arquitetura de processos, de governança, que atenda todos os aspectos de TI. (A)

Os clientes de sourcing, tampouco, estão preocupados com as certificações oferecidas pelas diversas metodologias para gestão. Aqueles que se preocupam com isto são os fornecedores, que utilizam esse mecanismo para sinalizar a qualidade dos seus produtos e serviços ao mercado. A razão para o olvido das certificações são a necessidade de adequação necessária e a rigidez que esta traz.

O pessoal quer usar as práticas, mas não quer rigidez de uma avaliação [para uma certificação]. (A)

O modelo eSCM, a despeito de suas qualidades, tende a ser um modelo pouco adotado por razões como custo, escassez de capital humano e dinâmicas concorrenciais.

\footnotetext{
${ }^{6}$ As expressões que aparecem entre colchetes são os elementos a que os informantes referem-se.
} 
A implantação completa deste modelo é custosa, em função das necessidades de adequação da estrutura organizacional e investimentos em ferramentas, treinamentos e consultorias. Poucas empresas possuem capital para tanto.

(...) eu acho, particularmente, que vai demorar muito [a adoção do eSCM] porque é muito dinheiro, muito dinheiro, muito dinheiro. Se é empresa nacional, nenhuma tem bala para isso. Nenhuma! (A)

A dependência de capital humano especializado é outro fator que impede a massificação do eSCM. As organizações que implementam tais práticas, o fazem por motivações de alguns indivíduos. Quando estes saem da organização, o uso da prática tende ao declínio.

(...) [a adoção do modelo é] muito dependente de pessoas, né? Então, pô, se você tem uma pessoa que tem capacidade de usar e isso trouxer benefícios para a organização, beleza. (...) [mas se] mudou as pessoas, mudou a filosofia. (A)

Um fator importante, destacado por B, é a importância de modelos de governança na dinâmica concorrencial do mercado de serviços de TI. Ainda que o eSCM seja desenvolvido por um consórcio com representantes dos fornecedores, clientes e academia, o modelo de membresia do ITSqc Research Consortium incentiza a participação dos grandes fornecedores, pois somente eles possuem um orçamento de US\$500.000,00 anuais para investigar em pesquisa. Por esse motivo, o eSCM acaba sendo um modelo enviesado para os grandes fornecedores.

\footnotetext{
Porque na verdade ele [o eSCM] tem uma adoção muito pequena, e ela tende a ser pequena, porquê? Porque ele está sendo desenvolvido em um fórum que tem um peso muito maior de fornecedores, e poucos fornecedores, do que de usuários. Então, ele acaba tendo um peso muito grande dos desejos de poucos fornecedores. E esses poucos fornecedores querem ter um padrão. Que é justamente se eu conseguir fazer que exista um padrão, eu vou conseguir eliminar aqueles fornecedores que estão muito fora desse padrão ou que não consigam convergir para esse padrão. (B)
}

Uma outra perspectiva, mais otimista, percebe o eSCM como um modelo mais próximo da realidade das organizações contemporâneas.

É perfeitamente adequável em função das mudanças culturais que estamos passando. (C)

\subsubsection{Validação das análises das premissas do modelo eSCM}

Premissa 1: A excelência e o sucesso da iniciativa de sourcing estão associados com a adequação às recomendações do eSCM. 
Assim como analisado, essa premissa é parcialmente válida. A simples e única adoção do eSCM não é condição suficiente para o sucesso do sourcing. O modelo contribui para um aumento da capacidade de execução.

(...) eu acho que a excelência está associada com a adoção do eSCM e [ênfase] outros modelos! Naquilo que se adequa mais a sua maturidade, a sua capacidade de executar. Não adianta fazer um processo maravilhoso, mas não ter capacidade de executar. (A)

Premissa 2: Deve existir uma objetividade das decisões, as quais devem ser baseadas em critérios.

O conceito de objetividade pode ser culturalmente dependente. Apregoar a objetividade como criterio sine qua non para o sucesso é controverso. Essa premissa é totalmente válida em uma cultura que privilegie tal aspecto, na qual isso é visto como uma boa qualidade.

Então toda a forma de você se relacionar no outsourcing acaba sendo complicada por isso. Se você está em uma empresa americana, uma empresa americana vai querer que o contrato especifique bem claramente o que pode e o que não pode, detalhe bem claramente o que é responsabilidade do comprador e o que é responsabilidade do fornecedor, que é o que diz, mais ou menos, o manual do eSCM. (B)

Essa postura de objetividade, pode levar a uma rigidez da relação entre cliente e fornecedor, a um entendimento estrito dos termos contratuais:

E em um contrato seguindo essas premissas do eSCM, você teria contratos rigidamente definidos. E na hora de eu implantar o serviço eu não iria implantar nada a mais, nem a menos do que estava previsto no contrato. Na hora da manutenção, eu, também, não irei fazer nada a mais nem a menos do que estava previsto no contrato. (B)

Assim, em culturas mais flexíveis como a brasileira pode ser vantajoso para ambos os clientes deixarem os instrumentos contratuais e gerenciais mais flexíveis.

Essa é uma premissa que pode invalidar a adoção do eSCM no contexto institucional brasileiro.

Premissa 3: As atividades da operação de terceirização devem ser documentadas e formalmente descritas, informando os papéis e as responsabilidades.

Oposto ao proposto na análise, o especialista acredita ser viável e com boas implicações tais práticas.

(...) eu não acho difícil, eu não vejo dificuldade nenhuma (...) sempre ouço aquela máxima do Demming que "em Deus eu acredito, o resto tudo é dado". 
Se você é um CIO, e você consegue se munir de dados, das volumetrias dos seus serviços, dos seus sistemas, do teu atendimento, então você consegue convencer o pessoal do negócio a trabalhar no mesmo time... então, particularmente, eu não vejo dificuldades em fazer isso. (A)

\section{Premissa 4: A hierarquia de comando e relacionamentos devem ser claros e objetivos.}

De forma oposta à análise, o informante concorda com a validade dessa premissa.

(...) protocolos claros, você tem projeção de demanda, você tem contratos de longo-prazo, você tem SLA bem definidos, você tem métricas bem definidas. Os acordos de níveis de serviços já são padrões. Quando o cliente manda para a fábrica de software, ele já sabe qual é o prazo, entendeu? Você não vai estimar. Aquilo já foi acordado, dentro das características das solicitações. (A)

Premissa 5: As estratégias de sourcing e de negócio devem estar alinhadas entre si.

Essa premissa foi superficialmente abordada nas entrevistas. Os informantes indicam concordar com sua validade. Contudo, não foi discutido suas implicações.

Premissa 6: A arquitetura tecnológica e as estratégia de sourcing devem estar alinhadas.

Essa premissa foi superficialmente abordada nas entrevistas. Os informantes indicam concordar com sua validade. Contudo, não foi discutido suas implicações.

Premissa 7: Racionalidade instrumental. Essa premissa não foi debatida com os informantes.

Premissa 8: A comunicação privilegia a transmissão unilateral de informação.

Em concordância com a análise, a premissa do modelo da comunicação como transmissão de informação pode ser um fator que invalide a aplicação do modelo. Em um contexto institucional ambigüo, a comunicação deve ter um papel central de forma a se alcançar um pleno entendimento por todas as partes.

a experiência nossa mostra que a maior parte dos contratos que não dão certo por causa do relacionamento, e não por causa do serviço em si. E sim, porque não se cumpre o que a outra parte está esperando. (B)

Uma boa comunicação permite gerenciar a execução do sourcing ainda que seja com incompletudes contratuais.

Ou seja, você, quando faz tipicamente na nossa cultura, você acaba tendo um escopo mal definido, ele fica frouxo. Mas, no entanto, ele pode chegar a um acordo, porque durante a implantação a gente fecha o acordo, e, depois, durante a manutenção do serviço eu estou contente com você, porque você está fazendo o que eu quero, ou vice-versa. (B) 
Premissa 9: A relação informal limita-se à lembrança de datas e preferências dos indivíduos.

As relações informais vão até mesmo na negociação do contrato

Por exemplo, eu errei na estimativa de um software. Chego para ti. Aí você olha, chega e fala para mim: Olha isso precisa de 400 pontos de função, não era 200. Ai você chega para mim e diz. Tá bom, eu te arranjo mais três projetos para cobrir isso aí (...) ou seja, você tem que manter uma relação de parceria muito forte. (A)

Premissa 10: Os conflitos são tratados explicitamente. Os relacionamentos são ambígüos

Ambigüidade, isso é uma verdade. Você acha que o cara concordou contigo numa reunião, mas não concordou e faz de outro de jeito. (A)

Premissa 11: O controle ocorre pela estrutura organizacional. A tese do controle pela estrutura organizacional aparece no discurso do informante A. Para ele, as práticas de governança serão institucionalizadas quanto incorporadas às funções de controle interno.

Transformam aquilo num processo, instanciado para a organização. Uma vez que é dado, estabelece uma meta. A partir de agora esse processo para o sistema de controle interno, e é auditado. Ai, o pessoal segue! (...) Todos esses modelos estão entrando dentro dos sistemas de controle interno, entendeu? (A)

Contudo, essa associação com os mecanismos de controle interno possuem dificuldades em função de características culturais dos diversos grupos que compõem a organização Outro fator que influi é a complexidade do modelo

Agora que que é difícil implantar pelos aspectos culturais, isso sim é, com certeza. Extremamente difícil, mas a visão do brasileiro é sempre simplificar o máximo que der, é sempre simplificar. (A)

É preciso ter ferramentas de apoio

O pessoal não quer criar processos complexos, quer roteiros simples, fácil recuperação de informação. Pessoal não ter cultura de ler, então você precisa de monitores, precisa de mentoring, então a estratégia de mudança cultural na implementação tem que ser bastante pesada, em tudo que é lugar. (A)

Contudo nem todos os funcionários trabalham dessa forma

(...) tem uma empresa que implantou CMM5. No meio do caminho, teve um monte de gente que pediu as contas e foi embora, porque não iria trabalhar mais daquele jeito. (A) 
Premissa 12: A segurança institucional garante os direitos de propriedade. As empresas evitam empregar o sistema judiciário para execução dos seus contratos. Buscam mecanismos privados de resolução de conflito, como arbitragem. Outros mecanismos são empregados para a resolução de conflitos, como a trasferência de pessoal

(...) os serviços de TI são baseados pessoas... então [em caso de conflito] o pessoal faz transferência pura e simples, entendeu? Ah você não quer, eu tiro o pessoal, não te passo mais projeto, te dou um projetinho aí para você ir morrendo aos poucos, e pego teu pessoal e vamos pro outro lado (A)

O uso do sistema judiciário também está associado a percepção cultural do conflito

com o americano, se você está tendo um problema no contrato, não está cumprindo um contrato, você leva para discutir na justiça, porque você vai discutir aquele ponto. (...) Vai se discutir aquele ponto para se chegar a um consenso. Numa empresa de cultura tipicamente latina, não apenas brasileira, o que acontece? Se você tiver que levar para justiça, significa que nós nunca mais vamos conversar. Então você só leva para a justiça em última instância. (B)

O risco à garantia dos direitos de propriedades já aparece no próprio desenho do acordo. Nesse contexto é importante destacar a importância do advogado como "arquiteto organizacional", isto é, como o agente responsável pelo desenho do sistemas de incentivos. No momento em que a negociação deixa de ser entre as partes interessadas e passa a ser entre advogados existe o risco de que eles deturpem o sentido original do contrato:

Também, é prejudicial porque ele coloca penalidades que aumentam o risco. Aí o advogado do fornecedor entra na parada. Começam a discutir dois advogados, e o contrato que eles criam não refletem o interesse de quem estava negociando antes. (B)

Em alguns casos, o advogado do cliente coloca no contrato as diversas garantias permitidas pelos institutos legais. Contudo, a exequibilidade de tais instrumentos é muito difícil ou demora tanto tempo que acaba perdendo valor. Em alguns casos, é melhor não dispor desses instrumentos e obter uma redução de preço do fornecedor.

Então, tem muita coisa que o advogado quer por de garantias, de prevenção, de multas que não são exequíveis. Eu costumo dizer para o cliente: "Tira essas multas daí, ou tira essas penalidades, ou tira essa restrições. Deixa o cara trabalhar mais solto, e em compensação arranca dele preço. Porque você vai tirar o risco dele, e vai ter como benefício do preço. Porque esse risco que você impôs para ele, você está pagando por aquele risco, e no dia que você quiser acionar ele, você não vai conseguir. (B)

A ausência de segurança institucional pode estar associada com a lentidão do sistema judiciário para julgamento das causas. 
o judiciário é ruim no sentido de que ele demora muito tempo para tomar uma ação (...)ele atrapalha porque não dá garantias, porque o tempo é muito importante para essa garantia ter valor. Como ele não me dá o tempo adequado, aquela garantia não me serve nada. (B) 


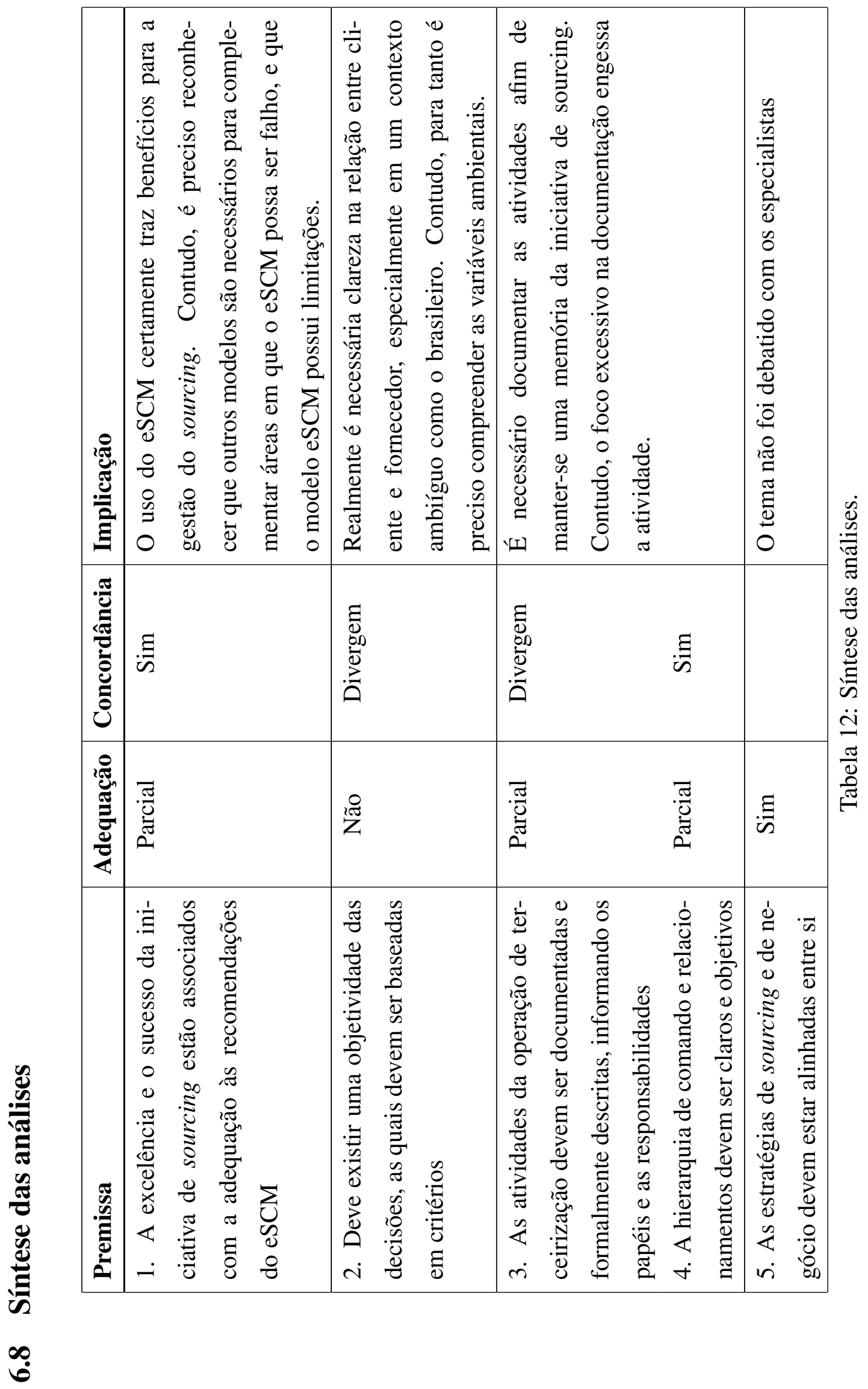




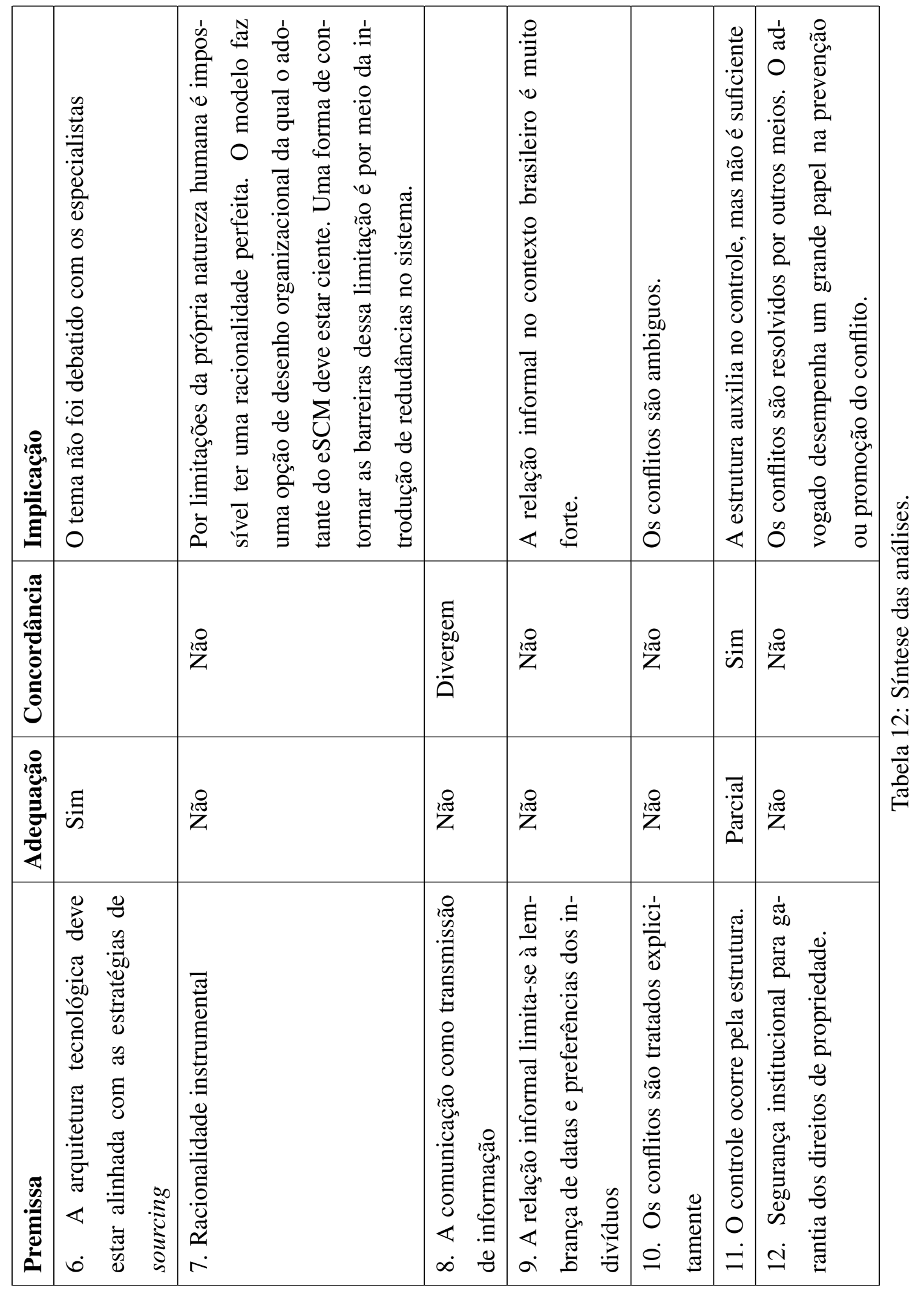




\section{CONCLUSÃO}

\subsection{O novo contexto}

O crescimento da terceirização e outras formas de fornecimentos (sourcing) de serviços de tecnologia da informação (TI) fazem emergir novos desafios para os responsáveis pela gestão da TI nas organizações, dentre os quais figura a governança de sourcing. Em menos de uma década assistiu-se a uma mudança profunda no mercado de serviços de TI. Passou-se de um modelo de fornecimento baseado em fornecedor único para outro com múltiplos e distintos fornecedores. Novas opções estão disponíveis, tais como crowdsourcing, open sourcing ou mash up de sistemas. Quais os reflexos dessas mudanças sobre a governança do sourcing?

Paralelamente, o ambiente de negócios tem recebido uma regulação crescente. Marcos regulatórios como Basiléia II, Sarbannes-Oxley Act, e outros impõem novas restrições às atividades empresarias e torna mais rígida o disclosure. O reflexo imediato aparece nas áreas de TI das organizações, as quais enfrentam o dilema de lidar com a complexidade do mercado de serviços de TI ao mesmo tempo em que aumentou-se o controle institucional sobre suas atividades.

\subsection{Mecanismos de governança}

Como forma de solucionar, ainda que parcialmente, esse dilema nos últimos anos tem surgido modelos para governança de TI. Esses modelos compreendem um conjunto de processos padronizados tidos como as "melhores práticas" do mercado. É possível encontrar melhores práticas para desenvolvimento de software (CMMi - Capability Maturity Model Integration), para gerenciamento de projetos (PMBoK - Project Management Book of Knowledge), para controle de TI (COBIT - Control Objectives for Information Technology), para infra-estrutura (ITIL Information Technology Infrastructure Library), e, obviamente, para fornecimento de serviços (eSCM - eSourcing Capability Model).

Esses modelos, assim como qualquer outro modelo, possuem premissas, cujo atendimento é necessário para a aplicabilidade das suas recomendações.

Conceitualmente, as premissas situam-se no nível das instituições. E em alguns casos essas premissas podem ser consideradas instituições que, como define North (1990), são as regras do jogo que tornam possíveis as interações sociais e econômicas.

Analisando-se a literatura de mecanismos de governança produzida nos campos de administra- 
ção, sociologia e economia, observa-se que existem quatro arranjos básicos de mecanismos de governança. A estrutura desses arranjos varia de acordo com as instituições que o fundamentam.

\begin{tabular}{|c|c|c|}
\hline \multirow{3}{*}{$\begin{array}{l}\text { Inst. atomistas } \\
\text { Inst. holísticas }\end{array}$} & Inst. não planejadas & Inst. planejadas \\
\hline & Mercado (recompensa) & Contrato (lei) \\
\hline & Comunidade (valores) & Hierarquia (poder) \\
\hline
\end{tabular}

O mecanismo de governança por excelência é o mercado. Ele é referencial para a análise dos demais. O mercado funciona como um sistema de equilíbrio dos preços e alocação da renda e da riqueza, baseado na maximização da utilidade do consumo dos indivíduos e do lucro das firmas. Em um plano teórico, no qual garantem-se todos os seus pressupostos, o funcionamentos dos mercados é perfeito, e nenhum outro arranjo é possível.

Contudo, essa perspectiva é exclusivamente teórica. Não existe no mundo real. O que se observa nos fenômenos diversos fenômenos empíricos é a combinação de outros três tipos de instituições: a hierarquia, o contrato e a comunidade.

A hierarquia refere-se ao poder de comando do proprietário do capital. Se a definição jurídica de propriedade, derivada do direto Romano, é baseada na possibilidade uso, usufruto e abuso de um determinado bem, a governança por meio desses mecanismo pressupõe um controle a partir da restrição aquele bem. No caso das firmas, o empresário possui o controle do capital e negocia esse bem com os trabalhadores.

A garantia da propriedade pressupõe a existência de outro arranjo: a lei. A lei serve como mecanismo de garantia de que a propriedade privada, e portanto o capital, não vá ser expropriada.

A lei, também, serve para garantir que determinadas promessas, quando feitas de livre vontade entre as partes, sejam executadas. Como postula o bordão latino pacta sunt servanda, ou seja, cumpra-se o acordado. Esse conceito é a base da moderna teoria dos contratos.

Finalmente existem instituições que não controlam diretamente o capital, tampouco possuem mecanismos formais de garantia. Trata-se das instituições comunitárias, cuja base são os valores. Esse grupo de instituições situa-se no âmago das práticas sociais, e influenciam diretamente os outros arranjos.

Os valores de um grupo influenciam a legitimidade de determinadas transações firmas. Por exemplo, no mundo ocidental é costumeiro o mercado de relações sexuais, ao passo que em países de cultura mulçumana tal prática é rejeitada e aqueles que a fazem podem ser condenados a morte. Esse exemplo, ainda que trivial, mostra que os valores sociais constituem um dos elementos que determina a fronteira da firma (o objeto da transação), o mercado (se a transação pode ocorrer) e a lei (é possível transacionar ou não). 
É importante observar que esses três tipos de instituições são formas ideais, cuja única finalidade é didática. No mundo real elas misturam-se, criando as instituições privadas (BROUSSEAU; RAYNAUD, 2006), instituições válidas para um determinado grupo. Tais instituições, por sua vez, criam mecanismos de governança híbridos (MÉNARD, 2004).

Retornando ao problema da governança de sourcing, deparamos-nos coma seguinte problemática: como as premissas (ou as instituições propostas) por um determinado modelo, desenvolvido em um determinado contexto, pode ser transposto para outro contexto com características distintas?

Tomemos o caso do eSourcing Capability Model (eSCM), um modelo desenvolvido no Information Technology Services Qualification Center, na Universidade de Carnegie Mellon para governança do sourcing de TI. Esse modelo foi desenvolvido dentro de uma universidade norteamericana, para organizações norte-americanas ${ }^{1}$, pressupondo um contexto econômico e jurídico norte-americano, e com valores éticos norte-americanos. Como ele poderia, então, ser aplicado no Brasil?

Seria o Brasil igual aos Estados Unidos? Certamente que não. A solução para compreender a aplicabilidade do modelo perpassa a compreensão das premissas institucionais do eSCM e brasileiras.

\subsection{Conclusões da pesquisa}

Diante dessa problemática, propôs-se a seguinte questão de pesquisa: Quais as implicações das premissas do modelo eSCM para sua aplicabilidade ao contexto institucional brasileiro?

Esse questionamento desdobrou-se em:

1. Quais as premissas do eSCM?

2. Como essas premissas se articulam no contexto institucional brasileiro?

Para identificar as premissas do eSCM aplicaram-se técnicas de análise de conteúdo (BARDIN, 2008) a um conjunto de textos selecionados (corpus) de recomendações.

As recomendações abrangem as práticas de estratégia ${ }^{2}$, governança ${ }^{3}$ e relacionamento ${ }^{4}$. Ao final da análise, identificou-se um conjunto de 12 premissas, explícitas e implícitas, quais sejam:

\footnotetext{
${ }^{1}$ Ainda que essas organizações possuam operação global, sua origem é norte-americana.

${ }^{2}$ Sourcing Strategy Management.

${ }^{3}$ Governance management.

${ }^{4}$ Relationship management.
} 
1. A excelência e o sucesso da iniciativa de sourcing estão associados com a adequação às recomendações do eSCM;

2. Deve existir uma objetividade das decisões, as quais devem ser baseadas em critérios;

3. As atividades da operação de terceirização devem ser documentadas e formalmente descritas, informando os papéis e as responsabilidades;

4. A hierarquia de comando e relacionamentos devem ser claros e objetivos;

5. As estratégias de sourcing e de negócio devem estar alinhadas entre si;

6. A arquitetura tecnológica deve estar alinhada com as estratégias de sourcing;

7. Racionalidade instrumental;

8. A comunicação como transmissão de informação;

9. A relação informal limita-se à lembrança de datas e preferências dos indivíduos;

10. Os conflitos são tratados explicitamente;

11. O controle ocorre pela estrutura organizacional;

12. Segurança institucional para garantia dos direitos de propriedade.

Caracterizar o ambiente institucional brasileiro, a fim de compará-lo com as premissas do eSCM, é uma tarefa metodologicamente complexa e qualquer resultado será incompleto e limitado, uma vez que é impossível a um único modelo englobar todas as especificidades de um país multicultural com o Brasil. Ainda assim, a empreita é válida.

A solução encontrada foi caracterizar o Brasil a partir do trabalho de sociológos como Gilberto Freyre, Sergio Buarque de Holanda, Darcy Ribeiro e Roberto DaMatta. Wood Jr e Caldas (1998) sintetizam as análises desses autores e as aplicam ao contexto empresarial brasileiro. Sua análise classifica as especificidades em: institucionais, culturais e organizacionais.

O modelo de especificidades de Wood Jr e Caldas (1998), as premissas enunciadas do eSCM e as comparações foram apresentadas a três especialistas para validação.

Validação do modelo cultural. O modelo cultural foi considerado válido e correto, porém com limitações. A primeira limitação levantada é que a adoção de modelo e metodologia de padronização de processos, como o eSCM, está sendo forçada por marcos regulatórios internacionais 
como Sarbannes-Oxley Act e acordo de Basiléia II. A entrada de diversas empresas em bolsas de valores também as força à implantação de controles padronizados.

A segunda limitação refere-se à possibilidade de generalização do modelo. Os informantes destacaram a existência de sub-culturas, em função da origem da organização, da localização geográfica ou mesmo das equipes organizacionais.

Uma terceira limitação é que a sociedade brasileira está passando por um processo de transformação, e a expansão das firma nacionais nos mercados estrangeiros está mudando a cultura empresarial nacional.

Validade do modelo eSCM. Indagados sobre a validade do modelo eSCM, todos os especialistas acreditam que o modelo trará contribuições à gestão do sourcing. Contudo, acreditam, também, que sua adoção será pequena por razões de custo e pelo fato de o modelo estar sendo desenvolvido em um fórum que tende a valorizar o ponto de vista dos grandes fornecedores mundiais.

Em resposta à pergunta de pesquisa proposta sobre quais as implicações das premissas do modelo eSCM para sua aplicabilidade ao contexto institucional brasileiro, é possível afirmar que certamente o modelo traz contribuições para uma gestão mais eficiente do sourcing de TI. Contudo, ele possui limitações em função das suas premissas. Algumas das premissas do modelo são difíceis de serem implantadas no contexto brasileiro, o que certamente compromete parcialmente o modelo.

Implicações da premissa 1. Ao assumir uma validade universal e suficiência lógica, o modelo faz fortes pressupostos sobre sua própria validade. A plasticidade e a permeabilidade da cultura brasileira facilitarão a adoção desse modelo, contudo, isso é um risco, uma vez que as recomendações podem ser tidas apenas como uma moda.

Implicações da premissa 2. A objetividade das decisões apregoada pelo modelo eSCM pode ser impraticável. Essa premissa do modelo pode interagir com especificidades como o personalismo e ambigüidade e gerar ruídos no processo de tomada de decisão.

Implicações da premissa 3. A ênfase na formalização e documentação das atividades da iniciativa de sourcing pode interagir com a característica formalista e criar uma aplicação do modelo apenas no plano discursivo, isto é, um simulacro.

Implicações da premissa 4. A clareza na hierarquia de comando e nos relacionamentos é um fator positivo do modelo, uma vez que pode reduzir a ambigüidade no processo de comando. Contudo, essa premissa pode degenerar em estruturas autoritárias. 
Implicações das premissas 5 e 6. Essas premissas foram pouco exploradas nas análises. Mas pela descrição existente na literatura, entende-se que o modelo é a melhor prática.

Implicações da premissas 7. A premissa de racionalidade instrumental dos agentes se traduz por uma escolha de desenho organizacional baseada na eficiência e alinhamento dos processos

Implicações da premissas 8. A premissa de comunicação como priorização da transmissão unidirecional de informacional é particularmente problemática em qualquer contexto, uma vez que não se torna possível de verificar se o receptor da mensagem realmente a compreendeu. A criticidade dessa premissa aumenta na presença de ambigüidades das relações sociais.

Implicações da premissas 9. Assumir essa premissa aumenta o risco de falha na implementação do modelo eSCM no contexto brasileiro, já que nesse contexto, os mecanismos de governança baseados na comunidade são centrais.

Implicações da premissas 10. No contexto institucional brasileiro, os conflitos não são tratados explicitamente. Assim, a implementação do modelo deveria incluir mecanismos que considerassem os sinais ambientais do conflito, além de mecanismos de resolução de disputas que não interfiram na reputação das partes no meio comunitário.

Implicações da premissas 11. O controle ocorre não somente pela estrutura organizacional, no contexto brasileiro. Os mecanismos informais atuam como forma de controle e de sanção.

Implicações da premissas 12. Claramente o ambiente institucional brasileiro não fornece uma segurança jurídica perfeita; ao contrário, o custo de se utilizar do sistema judiciário brasileiro é elevado. Assim, mecanismos alternativos de resolução de conflitos já devem ser pensados no momento da contratação.

Ademais, o modelo eSCM tem dificuldades para lidar com incertezas provenientes das interações humanas. A simples documentação e formalização dos processos não é suficiente.

Outro ponto crítico é que o modelo pressupõe o mercado como forma ideal de arranjo institucional, e desconsidera, ou dá pouca ênfase, aos elementos sociais que, também, servem para dar garantias e segurança às transações econômicas.

Concluindo, o modelo eSCM traz uma grande contribuição para a prática da gestão do sourcing que é a preocupação com a gestão por processos e um gerenciamento profissional. Outra contribuição significativa do modelo é o foco no alinhamento dos estratégias e operações.

Contudo, o modelo está fundamentado em uma lógica que presume uma racionalidade e formalismo que não são compatíveis com a cultura brasileira. São elementos que, historicamente, quando importados para o nosso contexto degeneraram-se e criaram arranjos ambigüos. 


\subsection{Recomendações para pesquisas futuras}

Infelizmente não pode ser realizado um estudo de caso de adoção real do eSCM, uma vez que no Brasil, atualmente, não existem casos suficientes de uso da metodologia. Um recomendação de pesquisa futura é o estudo da adoção da metodologia.

Um aspecto pouco desenvolvido nessa pesquisa foi a discussão do problema da importação de tecnologia gerencial no contexto da teorias pós-modernas de administração. O modelo eSCM faz um opção pelo modelo organizacional apregoado pela teoria clássica, a qual vem recebendo críticas crescentes.

No contexto brasileiro, os mecanismos de governança são fortemente baseados nas instituições comunitárias. Por isso a reputação de um fornecedor é um critério importante no momento da seleção. A maneira como esse aspecto influencia posteriormente a gestão é um elemento a ser aprofundado, possivelmente, através da construção de categorias de contextos organizacionais nos quais ocorrem a contratação e a gestão de terceirização dos serviços.

A pesquisa realizada assumiu a perspectiva das empresas privadas. Contudo, um dos maiores consumidores de TI no Brasil é o setor público. Assim, a aplicabilidade desses modelos no meio governamental é um estudo interessante pois ao mesmo tempo em que esse segmento tem as especificidades culturais próprias, existem restrições normativas completamente diferentes. 


\section{REFERÊNCIAS}

ABBEL, P. On the Prospects for a Unified Social Science: Economics and Sociology. Socio-Economic Review, v. 1, n. 1, p. 1-26, 2003.

ACKERBERG, D.; BOTTICINI, M. The choice of agrarian contracts in early renaissance tuscany: Risk sharing, moral hazard, or capital market imperfections? Explorations in Economic History, v. 37, n. 3, p. 241-257, 2000.

ADLER, P. Market, hierarchy, and trust: The knowledge economy and the future of capitalism. Organization Science, v. 12, n. 2, p. 215-234, 2001.

AGGARWAL, R. Role of risk sharing and transaction costs in contract choice: theory and evidence from groundwater contracts. Journal of Economic Behavior and Organization, v. 63, 2007.

AKERLOF, G. The Market for"Lemons": Quality Uncertainty and the Market Mechanism. The Quarterly Journal of Economics, JSTOR, v. 84, n. 3, p. 488-500, 1970.

ALCHIAN, A. A. Property rights. In: EATWELL, J.; MILGATE, M.; NEWMAN, P. (Ed.). The New Palgrave. London: Macmillan, 1987. v. 3, p. 1031-1034.

ANDRADE, O. Manifesto antropofágo. Revista de antropofagia, v. 1, n. 1, p. 3-7, 1928.

AOKI, M. Toward a Comparative Institutional Analysis. Cambridge: MIT Press, 2001.

ARON, R.; CLEMONS, E. K.; REDDI, S. Just right outsourcing: Understanding and managing risk. In: Proceedings of the 38th Hawaii International Conference on System Sciences. Hawaii: IEEE Computer Society Press, 2005.

ARROW, K. The Economics of Moral Hazard: Further Comment. American Economic Review, v. 58, n. 3 , p. 537-538, 1968.

ARROW, K. J. The limits of the organization. New York: Norton, 1974.

AUBERT, B. A.; PATRY, M.; RIVARD, S. Assessing the risk of it outsourcing. In: Proceedings of the Thirty-First Hawaii International Conference on System Sciences. [S.1.: s.n.], 1998.

AUBERT, B. A.; PATRY, M.; RIVARD, S. A framework for information technology outsourcing risk management. Advances in Information Systems, v. 36, n. 4, p. 9-28, 2005.

AXELROD, R. The Evolution of Cooperation. New York: Basic Books, 1984.

BAILEY, J. et al. Activity-based management of it service delivery. In: ASSOCIATION FOR COMPUTING MACHINERY. Proceedings of the 2007 symposium on Computer human interaction for the management of information technology. New York, 2007. 
BANDYOPADHYAY, S.; PATHAK, P. Knowledge sharing and cooperation in outsourcing projects-A game theoretic analysis. Decision Support Systems, v. 43, n. 2, p. 349-358, 2007.

BARDIN, L. Análise de conteúdo. Lisboa: 70, 2008.

BEBCHUK, L.; ROE, M. A Theory of Path Dependence in Corporate Governance and Ownership. Stanford Law Review, v. 52, n. 1, p. 127-170, 1999.

BECHT, M.; BOLTON, P.; RÖELL, A. Corporate governance and control. Cambridge: NBER, 2002. (National Bureau of Economic Research Working Paper).

BEULEN, E.; RIBBERS, P. Managing complex it outsourcing - partnerships. In: Proceedings of the 35th Hawaii International Conference on System Sciences. [S.1.: s.n.], 2002.

BEULEN, E.; RIBBERS, P. It outsourcing contracts: Practical implications of the incomplete contract theory. In: Proceedings of the 36th Hawaii International Conference on System Sciences. [S.1.: s.n.], 2003.

BROUSSEAU, E.; RAYNAUD, E. The economics of private institutions: an introduction to the dynamics of institutional frameworks and to the analysis of multilevel multi-type governance. Paris: Université Paris I, 2006. (Working paper).

BROWN, C.; MAGILL, S. Alignment of the IS functions with the enterprise: toward a model of antecedents. MIS Quarterly, v. 18, n. 4, p. 371-403, 1994.

CHANDLER, A. Strategy and structure. Cambridge: MIT Press, 1973.

CHEUNG, S. Transaction Costs, Risk Aversion, and the Choice of Contractual Arrangements. Journal of Law and Economics, JSTOR, v. 12, n. 1, p. 23-42, 1969.

COASE, R. H. The nature of the firm. Economica, v. 4, p. 386-405, 1937.

COMMONS, J. Legal Foundations of Capitalism. New York: Macmillan, 1924.

COMMONS, J. Institutional Economics: its place in political economy. New York: Macmillan, 1934.

COSTINOT, A. A Comparative Institutional Analysis of Agreements on Product Standards. San Diego: UCSD, 2008. (Department of Economics Working Paper, 2008-05).

CUERVO, A. Corporate Governance Mechanisms: a plea for less code of good governance and more market control. Corporate Governance, v. 10, n. 2, p. 84-93, 2002.

DAMATTA, R. O que faz o Brasil, Brasil? Rio de Janeiro: Rocca, 1986.

DAMATTA, R. A casa e a rua. Rio de Janeiro: Guanabara, 1987.

DAVIS, E.; STEIL, B. Institutional Investors. Cambridge: MIT Press, 2001.

DEMSETZ, H. The structure of ownership and the theory of the firm. Journal of Law and Economics, v. 26, n. 2, p. 375-390, 1983.

DIEDEREN, P.; JONKERS, H. Chain and Network Studies. Unpublished paper. KLICT. Chain Networks, Clusters \& ICT. The Netherlands, 2001. 
DOMBERGER, S.; FERNANDEZ, P.; FIEBIG, D. Modelling the price, performance and contract characteristics of IT outsourcing. Journal of Information Technology, v. 15, p. 107-118, 2000.

EASTON, G.; ARAUJO, L. Non-economic exchange in industrial networks. In: AXELSSON, B.; EASTON, G. (Ed.). Industrial Networks: A New View of Reality. London: Routledge, 1992. p. 62-84.

ELO, M. National culture and its impact on trust and cooperation in international business networks: Some empirical evidence from a greek-finnish business network. In: INTERNATIONAL MARKETING AND PURCHASING GROUP, 19., 2003, Lugano. Proceedings of the 19th Annual IMP Conference. Lugano: IMP, 2003.

ESWARAN, M.; KOTWAL, A. A Theory of Contractual Structure in Agriculture. American Economic Review, v. 75, n. 3, p. 352-367, 1985.

FARINA, E. M. M. Q.; AZEVEDO, P. F. de; SAES, M. S. M. A nova economia institucional. In: _ _ Competitividade: mercado, Estado e organizações. São Paulo: Singular, 1997. p. 19 $-111$.

FERNANDES, A. A.; ABREU, V. F. Implantando a governança de TI: da estratégia à gestão dos processos e serviços. 2. ed. Rio de Janeiro: Brasport, 2008.

FIANI, R. Teoria dos jogos. 2. ed. Rio de Janeiro: Elsevier, 2006.

FINKLE, A. Essays in the economics of information, incentives and the law. Tese (Doutorado) - University of Washington, Washington, 2004.

FORD, D. Understanding Business Marketing and Purchasing: An Interaction Approach. [S.1.]: Thomson Learning, 2002.

FREITAS, A. B. de. Traços brasileiros para uma análise organizacional. In: MOTTA, F. C. P.; CALDAS, M. P. (Ed.). Cultura organizacional e cultura brasileira. São Paulo: Atlas, 1997. p. $38-54$.

FREIWALD, S. Comparative Institutional Analysis in Cyberspace: The Case of Intermediary Liability for Defamation. Harvard Journal of Law and Technology, v. 14, p. 569, 2001.

FREYRE, G. Casa-grande \& senzala. 13.. ed. Rio de Janeiro: José Olympio, 1966.

FUKUYAMA, F. The end of history. In: BURNS, R.; RAYMENT-PICKARD, H. (Ed.).

Philosophies of History: From Enlightenment to Post-Modernity. Oxford: Blackwell, 2000. p. 318-319.

GORDON, J. N.; ROE, M. J. Introduction. In: GORDON, J. N.; ROE, M. J. (Ed.). Convergence and Persistence in Corporate Governance. Cambridge: Cambridge University Press, 2004. p. $1-30$.

GRANOVETTER, M. The Strength of Weak Ties. The American Journal of Sociology, v. 78, n. 6, p. 1360-1380, 1973.

GRANOVETTER, M. Economic Action and Social Structure: The Problem of Embeddedness. The American Journal of Sociology, JSTOR, v. 91, n. 3, p. 481-510, 1985. 
GRANOVETTER, M. Economic institutions as social constructions: A framework for analysis. Acta Sociologica, Nord Sociol Assoc, v. 35, n. 1, p. 3, 1992.

GRANOVETTER, M. The impact of social structure on economic outcomes. Journal of Economic Perspectives, v. 19, n. 1, p. 33-50, 2005.

GREIF, A. Cultural Beliefs and the Organization of Society: A Historical and Theoretical Reflection on Collectivist and Individualist Societies. The Journal of Political Economy, v. 102, n. 5, p. 912-950, 1994.

GUHA, S. et al. Comparing the eSCM-SP v2 and ISO 9001:2000. Pittsburgh: ITSqc, 2005.

GUMMESSON, E. Are current research approaches in marketing leading us astray? Marketing Theory, v. 1, n. 1, p. 27, 2001.

GUMMESSON, E. Total Relationship Marketing: Rethinking Marketing Management. [S.1.]: Butterworth-Heinemann, 2001.

HARDIN, R. Collective Action. [S.1.]: Johns Hopkins University Press, 1982.

HAYEK, F. A. The Use of Knowledge in Society. The American Economic Review, JSTOR, v. 35, n. 4, p. 519-530, 1945.

HAYEK, F. A. v. Direito, legislacao e liberdade : uma nova formulacao dos principios liberais de justica e economia politica. São Paulo: Visão, 1985.

HEFLEY, W. E.; LOESCHE, E. A. The eSourcing Capability Model for Client Organizations (eSCM-CL) v.1.1. Pittsburgh: ITSQc, 2006.

HODGSON, G. The Approach of Institutional Economics. Journal of Economic Literature, JSTOR, v. 36, n. 1, p. 166-192, 1998.

HOLLINGSWORTH, J. Advancing the socio-economic paradigm with institutional analysis. Socio-Economic Review, v. 1, n. 1, p. 130-134, 2003.

HOLLINGSWORTH, J.; BOYER, R. Coordination of economic actors and social systems of production. In: Contemporary Capitalism: The Embeddedness of Institutions. Cambridge: Cambridge University Press, 1997.

HYDER, E. B.; HESTON, K. M.; PAULK, M. C. The eSourcing Capability Model for Service Providers (eSCM-SP) v2.01. Pittsburgh: ITSQc, 2006.

JONES, C.; HESTERLY, W.; BORGATTI, S. A General Theory of Network Governance: Exchange Conditions and Social Mechanisms. The Academy of Management Review, JSTOR, v. 22, n. 4, p. 911-945, 1997.

KAUL, T.; PAULK, M. C. Comparing the eSCM-SP v2 and Six Sigma. Pittsburgh: ITSqc, 2006.

KERN, T.; WILLCOCKS, L. P. Exploring relationships in information technology outsourcing: the interaction approach. European Journal of Information Systems, v. 11, p. 3-19, 2002.

KNIGHT, F. H. Risk, uncertainty and profit. Chicago: Chicago University Press, 1921. 
KREPS, D.; WILSON, R. Reputation and Imperfect Information. Journal of Economic Theory, v. 27, n. 2, p. 253-279, 1982.

LAFONTAINE, F.; SLADE, M. Retail Contracting: Theory and Practice. The Journal of Industrial Economics, Blackwell Synergy, v. 45, n. 1, p. 1-25, 1997.

LICHBACH, M. The Cooperator's Dilemma. Michigan: University of Michigan Press, 1996.

MACNEIL, I. The Many Futures of Contracts. Southern California Law Review, v. 47, n. 688, p. 691-816, 1974.

MALLIN, C. Institutional Investors: The Growth of Global Influences. Corporate Governance: An International Review, v. 10, n. 2, p. 67-68, 2002.

MAXIMIANO, A. C. A. Introdução à administração. 5. ed. São Paulo: Atlas, 2000.

MÉNARD, C. The Economics of Hybrid Organizations. Journal of Institutional and Theoretical Economics, Mohr Siebeck, v. 160, n. 3, p. 345-376, 2004.

MOTTA, F. C. P. Cultura nacional e cultura organizacional. In: DAVEL, E.; VASCONCELLOS, J. (Ed.). Recursos humanos e subjetividade. Petrópolis: Vozes, 1996. p. 197-207.

MOTTA, F. C. P.; ALCADIPANI, R. Jeitinho brasileiro, controle social e competição. Revista de Administração de Empresas, v. 39, n. 1, p. 6-12, 1999.

MOTTA, F. C. P. a. 'For the English to See': The Importation of Managerial Technology in Late 20th-Century Brazil. Organization, v. 4, n. 4, p. 517-534, 1997.

NORTH, D. The historical evolution of politics. International Review of Law and Economics, v. 14, p. 381-391, 1994.

NORTH, D. C. Institutions, institutional change and economic performance. Cambridge: Cambridge University Press, 1990.

NORTH, D. C. Institutions, transaction costs and the rise of merchant empires. In: TRACY, J. D. (Ed.). The Political economy of merchant empires. Cambridge: Cambridge University Press, 1991. p. 22-40.

OLSON, M. The logic of collective action: public goods and the theory of groups. Cambridge: Harvard University Press, 1971.

OSTROM, E. Governing the Commons: The Evolution of Institutions for Collective Action. New York: Cambridge University Press, 1990.

PALAY, T. Comparative Institutional Economics: The Governance of Rail Freight Contracting. The Journal of Legal Studies, JSTOR, v. 13, n. 2, p. 265-287, 1984.

PERUNOVIĆ, Z.; PEDERSEN, J. L. Outsourcing process and theories. In: POMS 18th Annual Conference. [S.1.: s.n.], 2007.

POPPO, L.; ZENGER, T. Do formal contracts and relational governance function as substitutes or complements? Strategic Management Journal, v. 23, n. 8, p. 707-725, 2002.

PRADO JR, C. Formação do Brasil contemporâneo. 3. ed. São Paulo: Brasiliense, 1948. 
PRATES, M. A. S.; BARROS, B. T. de. O estilo brasileiro de administrar: sumário de um modelo de ação cultural brasileiro com base na gestão empresarial. In: MOTTA, F. C. P.; CALDAS, M. P. (Ed.). Cultura organizacional e cultura brasileira. São Paulo: Atlas, 1997. p. $55-69$.

PUTNAM, R.; LEONARDI, R.; NANETTI, R. Making democracy work: civic traditions in modern Italy. Princeton: Princeton University Press, 1993.

RHODES, M.; APELDOORN, B. V. Capital unbound? The transformation of European corporate governance. Journal of European Public Policy, v. 5, n. 3, p. 406-427, 1998.

RIBEIRO, D. O povo brasileiro: formação e sentido do Brasil. São Paulo: Companhia das letras, 1995.

RIGGS, F. W. A ecologia da administração pública. Rio de Janeiro: FGV, 1964.

RUIJTER, E. de; WEESIE, J. Working your Way in: How Trust Problems and Social Embeddedness Affect the Behavior of Home Maintenance Suppliers. Rationality and Society, v. 19, n. 1, p. 35, 2007.

SAMBAMURTHY, V.; ZMUD, R. Research Commentary: The Organizing Logic for an Enterprise's IT Activities in the Digital Era-A Prognosis of Practice and a Call for Research. Information Systems Research, v. 11, n. 2, p. 105-114, 2000.

SCHMIDT, R.; SPINDLER, G. Path Dependence, Corporate Governance and Complementarity. International Finance, v. 5, n. 3, p. 311-333, 2002.

SHIRLEY, M. M. What does institutional economics tell us about development? In: INTERNATIONAL SOCIETY FOR NEW INSTITUTIONAL ECONOMICS, 7., 2003, Budapest. Proceedings of the 7th Annual Conference of the International Society for New Institutional Economics. Budapest: ISNIE, 2003.

SIMON, H. Theories of Decision-Making in Economics and Behavioral Science. The American Economic Review, JSTOR, v. 49, n. 3, p. 253-283, 1959.

SPRADLEY, J. The ethnographic interview. New York: Holt, 1979.

STIGLITZ, J. Incentives and Risk Sharing in Sharecropping. The Review of Economic Studies, JSTOR, v. 41, n. 2, p. 219-255, 1974.

STREECK, W. Social science and moral dialogue. Socio-Economic Review, v. 1, n. 1, p. 126-129, 2003.

TAYEB, M. Organizations and National Culture: Methodology Considered. Organization Studies, v. 15, n. 3, p. 429, 1994.

WELLMAN, B.; BERKOWITZ, S. Social structures: a network approach. Cambridge: Cambridge University Press, 1988.

WHITLEY, R. Divergent Capitalisms: The Social Structuring and Change of Business Systems. Oxford: Oxford University Press, 1999.

WHITLEY, R. Editorial. Organization Studies, v. 21, n. 5, p. v-x, 2000. 
WILLIAMSON, O. E. the vertical integration of production: market failure considerations. The American Economic Review, American Economic Association, v. 61, n. 2, p. 112-123, 1971.

WILLIAMSON, O. E. Markets and hierarchies: analysis and antitrust implications: a study in the economics of internal organization. [S.1.]: Free Press, 1975.

WILLIAMSON, O. E. Transaction-cost economics: the governance of contractual relations. Journal of Law and Economics, v. 22, n. 2, p. 233-261, 1979.

WILLIAMSON, O. E. The economic institutions of capitalism. New York: Free Press, 1985.

WILLIAMSON, O. E. Comparative economic organization: The analysis of discrete structural alternatives. Administrative Science Quarterly, v. 36, n. 2, 1991.

WILLIAMSON, O. E. The Mechanisms of Governance. New York: Oxford University Press, 1996.

WOOD, G.; BREWSTER, C. Decline and renewal in the British labour movement: trend, practices and lessons for South Africa. Society in Transition, v. 33, n. 2, p. 241-57, 2002.

WOOD JR, T.; CALDAS, M. P. Antropofagia organizacional. Revista de Administração de Empresas, v. 38, n. 4, p. 6-17, 1998.

WURMAN, R. Information anxiety 2. Indianapolis: Que, 2000.

ZATTONI, A.; CUOMO, F. Why Adopt Codes of Good Governance? A Comparison of Institutional and Efficiency Perspectives. Corporate Governance: An International Review, v. 16, n. 1, p. 1-15, 2008.

ZYLBERSZTAJN, D.; LAZZARINI, S. On the survival of contracts: assessing the stability of technology licensing agreements in the brazilian seed industry. Journal of Economic Behavior and Organization, Elsevier, v. 56, n. 1, p. 103, 2005. 